UNIVERSIDADE FEDERAL DE MINAS GERAIS

Programa de Pós-graduação em Saneamento, MEIo AMBIENTE E RECURSOS HídRICOS

\title{
REJECTION OF PHARMACEUTICAL COMPOUNDS FROM SURFACE WATER BY NANOFILTRATION AND REVERSE OSMOSIS
}

Ana Flávia Souza Foureaux

Belo Horizonte

2018 


\section{REJECTION OF PHARMACEUTICAL COMPOUNDS FROM SURFACE WATER BY NANOFILTRATION AND REVERSE OSMOSIS}




\title{
REJECTION OF PHARMACEUTICAL COMPOUNDS FROM SURFACE WATER BY NANOFILTRATION AND REVERSE OSMOSIS
}

\author{
Dissertation presented to the Postgraduate Program in \\ Sanitation, Environment and Water Resources of Federal \\ University of Minas Gerais as a partial requirement to \\ obtain the title of Master in Sanitation, Environment and \\ Water Resources.
}

Concentration area: Environment Studies Research

Line: Characterization, prevention and control of pollution

Supervisor: D. Sc. Liséte Celina Lange

Co-Supervisor: D. Sc. Lucilaine Valéria de Souza Santos

Belo Horizonte

Escola de Engenharia da UFMG

2018 
F774r Rejection of pharmaceutical compounds from surface water by nanofiltration and reverse osmosis [manuscrito] / Ana Flávia Souza Foureaux. -2018.

iv, $76 \mathrm{f}$., enc.: il.

Orientadora: Liséte Celina Lange.

Coorientadora: Lucilaine Valéria de Souza Santos.

Dissertação (mestrado) - Universidade Federal de Minas Gerais, Escola de Engenharia.

Inclui bibliografia.

1. Engenharia sanitária - Teses. 2. Meio ambiente - Teses. 3. Água Purificação - Filtração - Teses. 4. Fármacos - Teses. I. Lange, Liséte Celina. II. Santos, Lucilaine Valéria de Souza. III. Universidade Federal de Minas Gerais. Escola de Engenharia. IV. Título.

CDU: 628(043) 
Rejection of pharmaceutical compounds from surface water by nanofilination and Twerte omosis

\section{ANA FLAVIA SOUZA FOUREAUX}

Dissertacho defendida e aprovada pela banea examinolora constituida pelos Senhores

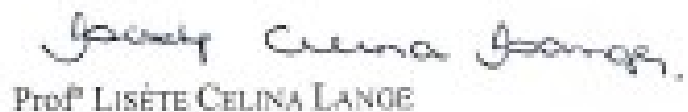

Prof Lisete Celiva Lanoe
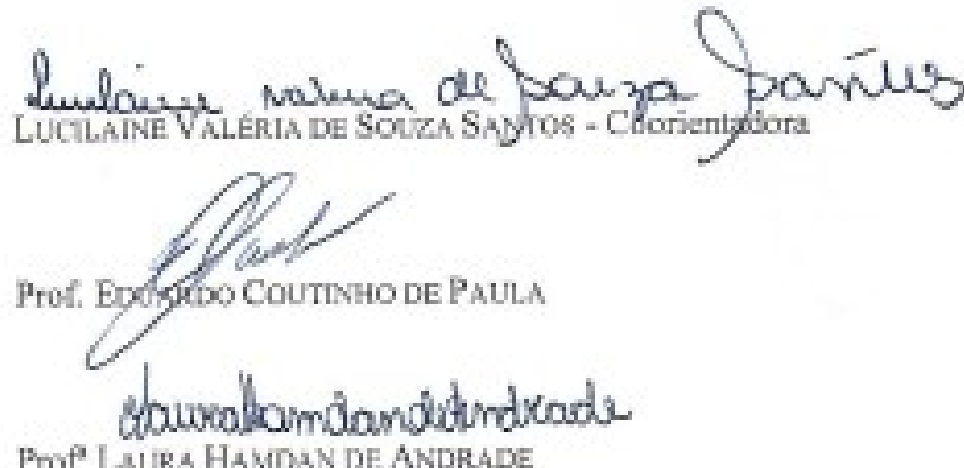

Prof LALRA HAMOAN DE ARDRADE

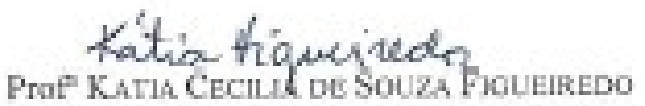

Aprovadi pelo Cologiado do PG SMARH

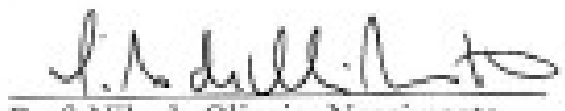

Prot. Nilo do Oliveira Wastimento Coondetador
Versăo Flnal apgovada por

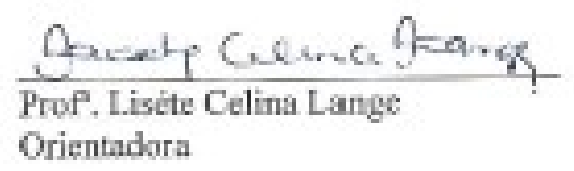

Belo Horizute, 20 de fencrein de $201 \mathrm{~s}$. 


\section{ACKNOWLEDGMENT}

I thank God for the gift of life, for my health and for always blessed me and my family.

I would like to express my infinite gratitude for my parentes Vera and Carlos for all dedication, love, affection, understanding, motivation, zeal and advices. You are my greatest examples of character and determination, are my sources of inspiration for me to continue to pursue my goals. Thank you so much for always supporting me.

I thank all my relatives, in special my aunt Rosângela, for the prayers and positive thoughts for me.

I would like to thank Henrique for all the affection and companionship, helping to make my days lighter and happier. Thank you for encouraging me, making me believe in my potential.

I thank my friend and godmother Leila Moller for the support, affection and opportunities.

I thank the friends I made at SMARH during these two years, especially my friend Duda. Thank you so much for every word of motivation. Thank you for the advice, cheering and congresses.

For their collaboration and support I would like to thank the CEFET-MG professors, especially, Wagner Moravia for the encouragement and help yielding the nanofiltration unit for the tests.

I would like to express my gratitude of postgraduate program and to all teachers of DESA, especially my supervisor Liséte Lange, for all teaching, conversations, advice and patience. My co-supervisor, Lucilaine Santos, thank you for the countless help and for being so helpful. I also thank Professor Miriam Amaral for the help, teaching and encouragement of my work. Thank you so much for having trusted in my work thus contributing to my personal and professional growth.

I thank the SIGERS and GEAPS research groups for the opportunities offered, for each learning and help. I am especially grateful to Luiza Barros for sharing with me the collections and the difficulties of analyzing the water of the Doce river. 
To the students of scientific initiation Julia, Nayara, Victor and Yuri I thank for the commitment and indispensable help for the development of this project.

I would like to thank the lab technicians Gabriel and Érico for always helping me and clarifying doubts.

I thank the Central Water Treatment Plant of Governador Valadares for always receiving me well and contributing a lot for the development of the research.

I thank CNPq for the scholarship granted. CAPES and FAPEMIG for fouding the many researchers developed by the group and FUNASA for the financing the project "Avaliação da ocorrência de fármacos na água para consume humano: subsídios para a inserção no padrão de potabilidade brasileiro", which this research is part. 


\begin{abstract}
Pharmaceutical compounds represent a diverse set of biologically active molecules used in human and veterinary medicine. The increase in the consumption of these drugs contributes to the constant occurrence of these compounds in aquatic environments. The situation is even more serious in conditions of absence of sewage treatment system. This is the case of the city of Governador Valadares, located in the state of Minas Gerais, thus discharging all its effluent to the Doce river that supplies the region. In order to guarantee the quality of water, especially for human consumption, investments in additional treatments are necessary. Among these technologies, the use of membranes, which combine the stability of the process with the excellent quality of the treatment, stands out. Thus, nanofiltration (NF) and reverse osmosis (RO) membranes were tested aiming at the pharmaceutical compounds retention in the Doce river raw water. This study was divided into three steps. In the first one, pharmaceutical compounds occurrence in all samples of the Doce river raw water was investigated. Among the pharmaceutical compounds that were found, the following stand out: Phenylbutazone and Prednisone that were rejected in 98 and $80 \%$, respectively, by the DK membrane, whereas Betamethasone was 40.85 removed by this membrane. In addition, the efficiency of Governador Valadares central water treatment plantwas also assessed, which showed a reduction in the concentration of the pharmaceutical products in the potable water when compared to the Doce river raw water. The second part investigated five NF and two RO membranes that were tested to evaluate the physico-chemical quality and the presence of pharmaceutical compounds in permeates. Additionally, the resistance, permeability and specific energy consumption (SEC) for each membrane were assessed. It was observed a removal high efficiency of the parameters evaluated for the RO membranes, however, these membranes presented the highest resistance, energy demandand lower permeate fluxes. Dense NF membranes presented abetter set of results. The third phase refers to the choice of the best operational condition, evaluating the best transmembrane pressure and feed flow for permeates production with high quality in the physical and chemical parameters, as weel asthe drugs removal compareted with the Doce river raw water. The best operational condition obtained in the study was 10 bar of pressure and feed flow of $3.2 \mathrm{~L} / \mathrm{min}$ which presented permeates flow at $45.99 \mathrm{~L} / \mathrm{m}^{2} . \mathrm{h}$ and a SEC of $0.44 \mathrm{KWh} \cdot \mathrm{m}^{3} \mathrm{~m}^{2}$.
\end{abstract}

Keywords: Nanofiltration, reverse osmosis, water, pharmaceutical compounds 


\section{RESUMO}

Os fármacos representam um conjunto diversificado de moléculas biologicamente ativas utilizadas na medicina humana e na medicina veterinária. O aumento no consumo de medicamentos contribui paraa ocorrência constante desses compostos em ambientes aquáticos. Em condições de ausência de sistema de tratamento de esgoto, a situação é ainda mais grave. É o caso da cidade de Governador Valadares, localizada no estado de Minas Gerais, que lança todo o seu efluente no rio Doce, que abastece a região. Para garantir a qualidade da água, principalmente a destinada ao consumo humano, são necessários investimentos em tratamentos adicionais. Dentre essas tecnologias, destaca-se o emprego de membranas, que combinam a estabilidade do processo com a excelente qualidade do tratamento. Dessa forma, membranas de nanofiltração (NF) e osmose inversa (OI) foram testadas visando à retenção de fármacos na água bruta do rio Doce. O estudo foi dividido em três fases. Na primeira, foram investigados os fármacos presentes em todas as amostras coletadas no rio Doce, destacando a ocorrência dos seguintes: Fenilbutazona e Prednisona, que tiveram a retençãode 98 e $80 \%$ pela membrana DK, enquanto a Betametasona teve rejeição de $40.85 \%$ por essa membrana. Além disso, a eficiência da estação central de tratamento de água de Governador Valadarestambém foi avaliada, a qual apresentou redução na concentração dos produtos farmacêuticos na água potável quando comparado à água bruta do rio Doce. Na segunda parte foram testados cinco tipos demembranas de NF e dois tipos de OI para avaliação da qualidade físico-química e de presença de compostos farmacêuticos nos permeados. Adicionalmente, foram avaliadosas resistências, permeabilidades e gastos da energia especifica para cada membrana. Foi observada uma alta eficiência de remoção dos parâmetros avaliados para as membranas de OI, porém, essas membranas apresentaram as maiores resistências, gastos energéticos e menores fluxos de permeado. As membranas de NF densas apresentaram ummelhor conjunto de resultados. A terceira fase refere-se à escolha da melhor condição operacional, avaliando a melhor pressão transmembrana e vazão de alimentação para a produção dos permeados com alta qualidade nos parâmetros físicoquímicos, bem como remoção dos fármacos em comparação à água bruta do rio Doce. A melhor condição operacional obtida no estudo foi de 10 bar de pressão e vazão de alimentação de 3,2 L/min que apresentou fluxo de permeado de $45,99 \mathrm{~L} / \mathrm{m}^{2}$.h e gasto de energia específica de 0,44 KWh. $\mathrm{m}^{3} \mathrm{~m}^{2}$.

Palavras-chave: Nanofiltração, osmose inversa, água, compostos farmacêuticos 


\section{SUMMARY}

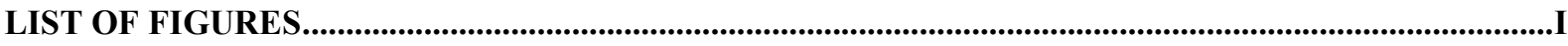

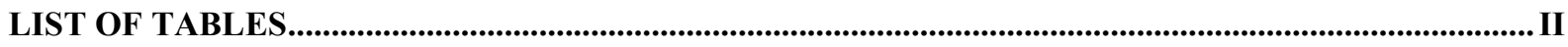

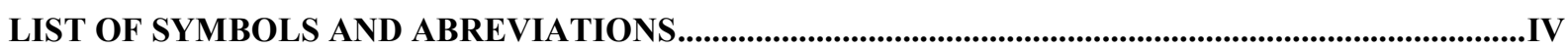

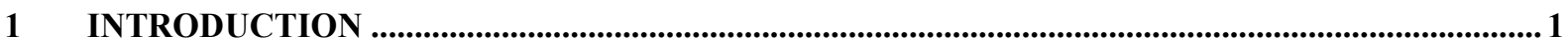

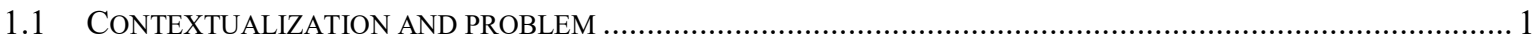

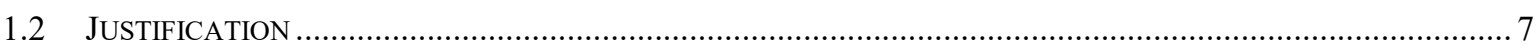

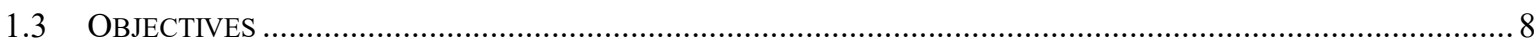

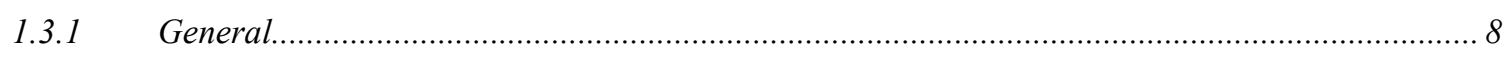

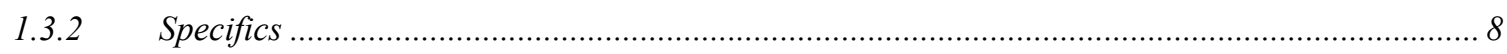

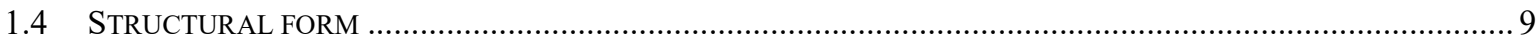

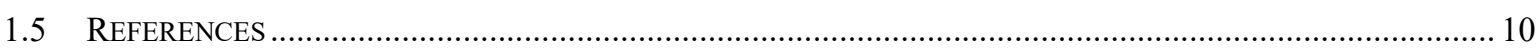

2 EVALUATION OF THE PHARMACEUTICAL COMPOUNDS OCCURRENCE IN THE DOCE

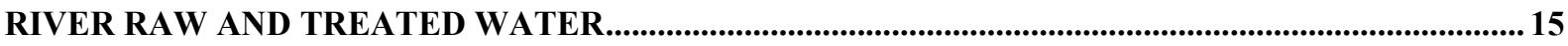

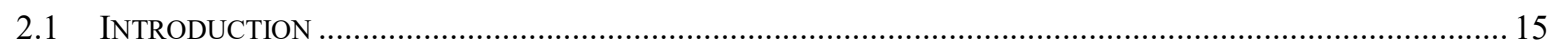

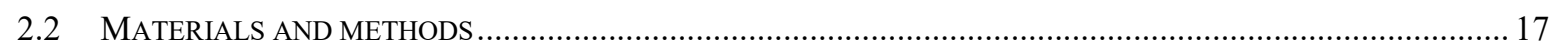

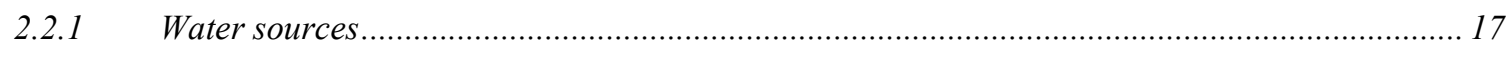

2.2.2 Pharmaceutical compounds identification ........................................................................ 17

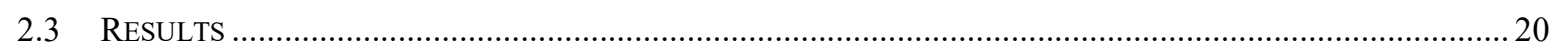

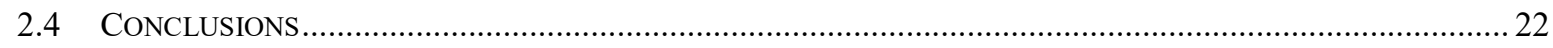

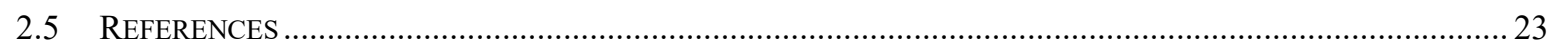

3 EVALUATION OF NANOFILTRATION AND REVERSE OSMOSIS MEMBRANES TO DRUGS REMOVAL IN THE DOCE RIVER RAW WATER .........................................................................25

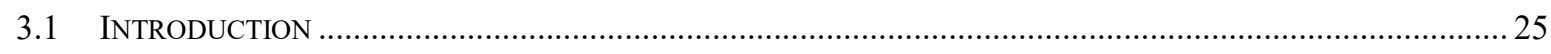

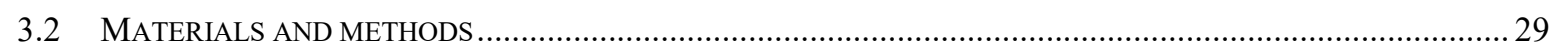

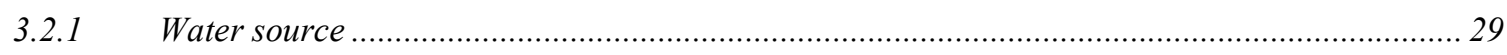

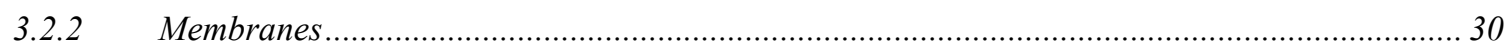

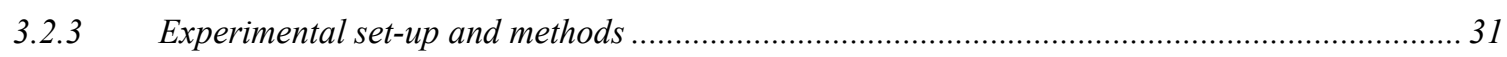

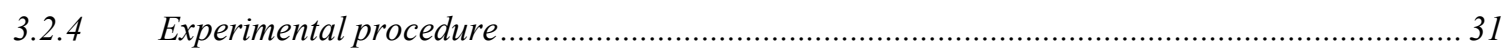

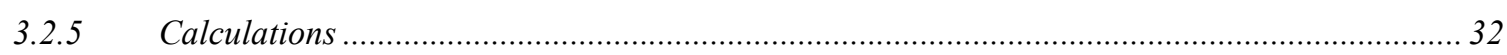

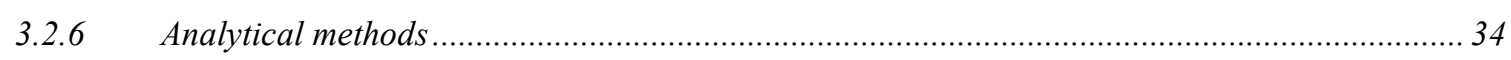

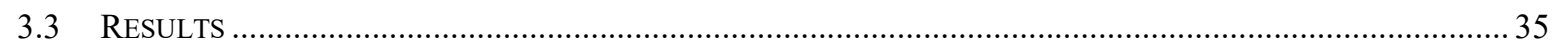

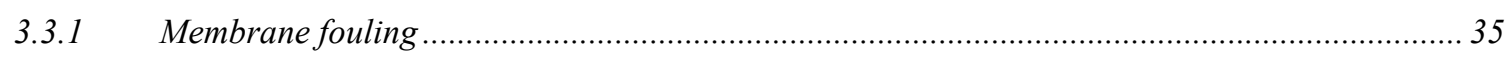

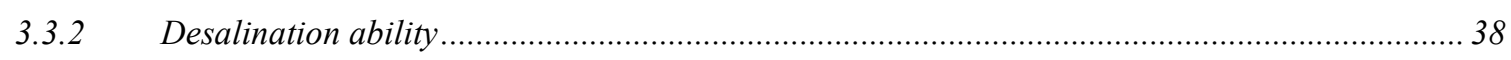

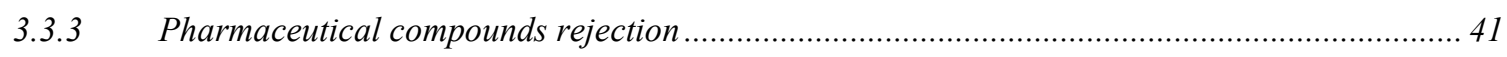

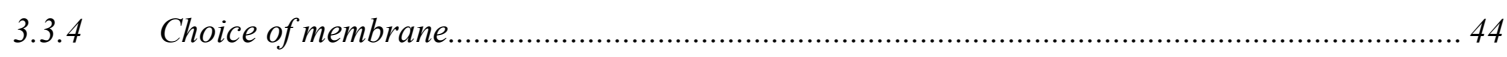

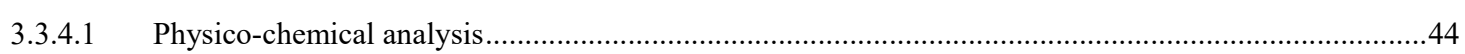

3.3.4.2 Evaluation of the resistances, permeabilities and specific energy demand for the DK membrane of nanofiltration using the surface water ......

3.3.4.3 Removal comparison of the pharmaceuticals compounds present in the surface water by DK membrane and conventional WTP 


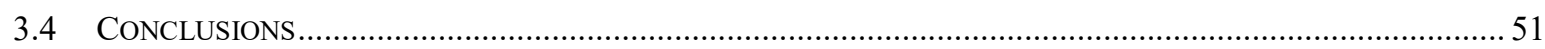

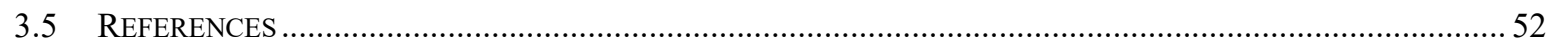

4 EVALUATION OF THE BEST TRANSMEMBRANE PRESSURE AND FEED FLOW RATE TO DK MEMBRANE

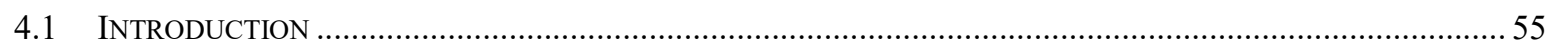

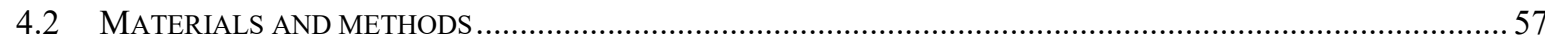

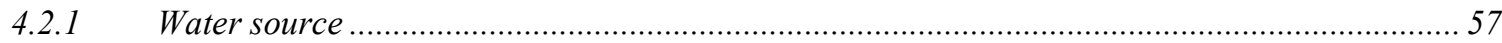

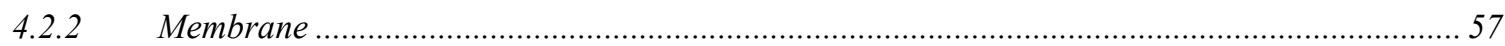

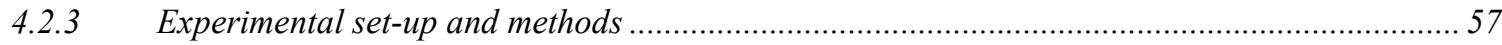

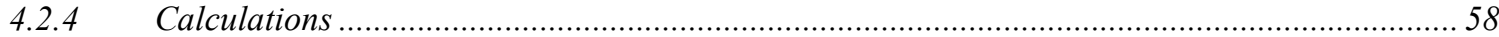

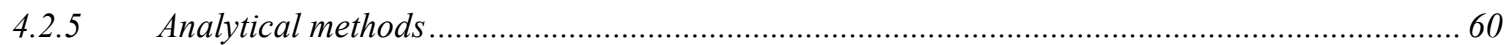

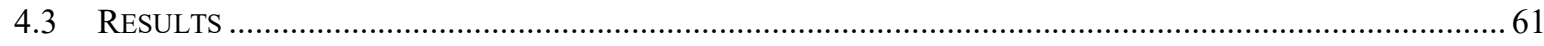

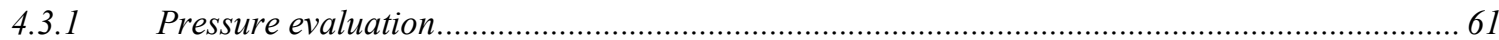

4.3.1.1 Evaluation of the resistances, permeabilities and specific energy demand for each pressure evaluated..61

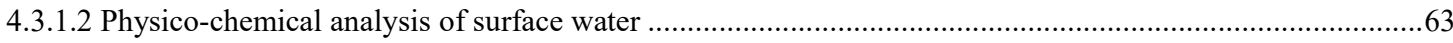

4.3.1.3 Evaluation of pharmaceutical compound retention varying the transmembrane pressure ......................64

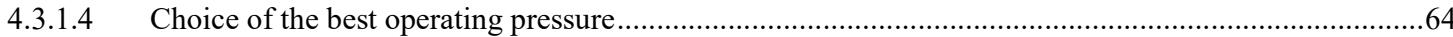

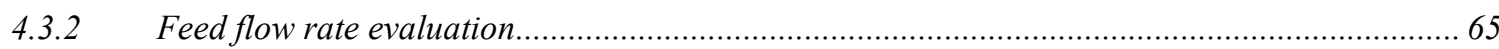

4.3.2.1 Evaluation of the resistances, permeabilities and specific energy demand for each feed flow rate evaluated 65

4.3.2.2 Analysis of the physical andchemical parameters for each applied feed rate ......................................67

4.3.2.3 Evaluation of pharmaceutical products retention varying the feed flow ..............................................68

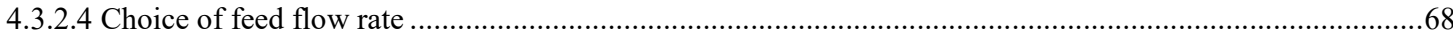

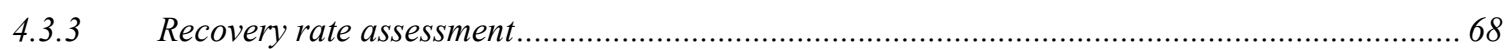

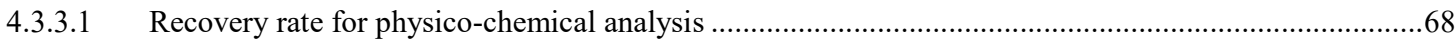

4.3.3.2 Evaluation of the pharmaceutical compounds presence along the recovery rate ..................................70

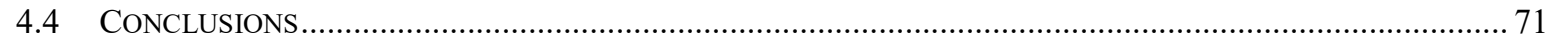

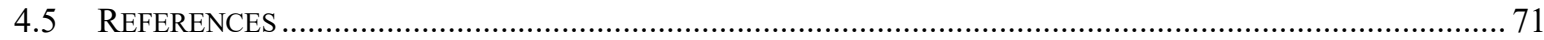

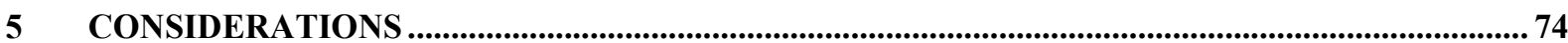




\section{LIST OF FIGURES}

FIGURE 1: Scheme of membrane separation process ......................................................

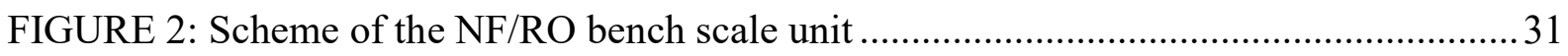

FIGURE 3: Fouling resistances (reversible and irreversible) in NF and RO membranes treating surface water $\left(x 10^{12}\right.$ for $N F$ membranes and $x 10^{13}$ for RO membranes) ..................... 36

FIGURE 4: Relation of physico-chemical results of surface water samples with total membrane resistance. 48

FIGURE 5: Physico-chemical parameters removal efficiency for each transmembrane pressure (TMP) evaluated and the relation of these parameters with the permeate flux and total resistance 63

FIGURE 6: Physical and chemical analyzes as well as the relation of these parameters with the flow and total resistance varying the feed flow.

FIGURE 7: Conductivity for the recovery rate for permeates of each surface water sample... 69

FIGURE 8: Turbidity, absorbance and TOC throughout the recovery rate for the first surface water sample 


\section{LIST OF TABLES}

TABLE 1: Retention percentage of some pharmaceutical products in aqueous matrices using NF and RO.

TABLE 2: Indicators of water, sewage and sewage treated by water consumed in Governador Valadares - MG

TABLE 3: Schedule of the colletc of the raw and treated water from the Doce river

TABLE 4: The most recurrent pharmaceutical compounds in the Doce river raw water, collected in April 2016, that were detected in the preliminary analysis of full scan using the mass spectrometer.

TABLE 5: Chromatrographic conditions for the quantification of the pharmaceutical compounds in the HPLC coupled to the mass spectrometer

TABLE 6: Evaluation of the presence of pharmaceutical compounds in the raw and treated water in the Central WTP of Governador Valadares.

TABLE 7: The structures and physico-chemical properties of the pharmaceuticals compounds that were found in the Doce river raw water

TABLE 8: Technical membranes characteristics evaluated in this study

TABLE 9: Permeate flux, flux decline along the test and specific energy consumed for each membrane evaluated in this study using 10 bar of pressure and $2.4 \mathrm{~L} /$ min of feed flow rate 37

TABLE 10: Physico-chemical analysis results of the surface water collected in April 2016, and of the permeates producted by NF and RO membranes using 10 bar of pressure and $2.4 \mathrm{~L} /$ min of feed flow rate

TABLE 11: Pharmaceutical compounds that were found in the surface water samples collected in April 2016 and their physico-chemical properties

TABLE 12: The pharmaceutical compounds found in the first surface water sample (April 2016) and in the permeates from five NF and two RO membranes evaluated in this study, where MQL is the method quantification limit

TABLE 13: Average, standard deviation and median of the physico-chemical results of surface water and permeates, as well as the removal efficiency of each parameter reached by the DK nanofiltration membrane.

TABLE 14: Permeate flux, resistences, flux decline, and specific energy consumed for each surface water sample using DK membrane applying 10 bar of tranmembrane pressure and feed flow rate $3.2 \mathrm{~L} / \mathrm{min}$

TABLE 15: Molecular structure and physico-chemical propertiesof Betamethasone.....

TABLE 16: Pharmaceutical compounds removal efficiency that were found in the surface water, using the DK membrane and in water complete cycle treatment ..............................50

TABLE 17: Technical properties of DK nanofiltration membrane........................................57

TABLE 18: Permeates flux, resistances, flux decline, and specific energy consumed during nanofiltration varying the transmembrane pressures at 4; 6;8 and 10 bar with the feed flow rate fixed in $2.4 \mathrm{~L} / \mathrm{min}$. 
TABLE 19: Pharmaceutical compound occurrence in the surface water and the permeates of each evaluated transmembrane pressure.

TABLE 20: Permeates flux, resistances, flux decline and specific energy consumed during nanofiltration varying the feed flow at $0.8 ; 1.2 ; 2.4$ and $3.2 \mathrm{~L} / \mathrm{min}$ at $10 \mathrm{bar}$ of pressure........66

TABLE 21: Pharmaceutical compound occurrence in the surface water and the permeates of

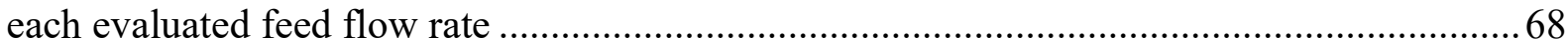

TABLE 22: Permeate flux and pharmaceuticals compounds removal in the first surface water sample (April 2016) along the DK membrane recovery rate ............................................... 70

Programa de Pós-graduação em Saneamento, Meio Ambiente e Recursos Hídricos da UFMG 


\section{LIST OF SYMBOLS AND ABREVIATIONS}

$\Delta \mathrm{P}$

$\Delta \mathrm{V}$

$\mathrm{A}_{\mathrm{M}}$

ABES

$\mathrm{C}$

CAS

COD

CONAMA

$\mathrm{CP}$

DESA

EC

EPA

EU

FD

FO

HPLC

$\mathrm{J}$

$\mathrm{J}_{\mathrm{cc}}$

$\mathrm{J}_{\mathrm{pc}}$

$\mathrm{J}_{\mathrm{w}}$

K

Log Kow

MDL

$\mathrm{MF}$

MQL

MS

MSP

MWCO

$\mathrm{NF}$
Transmembrane Pressure

Total Volume of the Permeate

Effective Membrane Filtration Area

Associação Brasileira de Engenharia Ambiental e Sanitária

Concentration

Code Issued by the Chemical Abstracts Service

Chemical Oxygen Demand

Conselho Nacional de Meio Ambiente

Concentration Polarization

Departamento de Engenharia Ambiental e Sanitária

Electric Conductivity

Environmental Protection Agency

European Union

Flux Decline

Frequence of Occurence

High Performance Liquid Chromatography

Permeate Flux

Permeate Flux After Chemical Cleaning

Permeate Fux After Physical Cleaning

Distilled Water Flow

Membrane Permeability

Octanol/Water Partition Coefficient

Method Detection Limit

Microfiltration

Method Quantification Limit

Mass Spectrometer

Membrane Separation Process

Molecular Weight Cut-Off

Nanofiltration

Programa de Pós-graduação em Saneamento, Meio Ambiente e Recursos Hídricos da UFMG 


$\begin{array}{cc}\mathrm{pH} & \text { Hydrogen Potential } \\ \mathrm{pKa} & \text { Constant of Acidity } \\ \text { PVDF } & \text { Polyvinylidene Fluoride } \\ \mathrm{Q}_{\mathrm{f}} & \text { Volumetric Feed Flow } \\ \mathrm{Q}_{\mathrm{p}} & \text { Volumetric Permeate Flow } \\ \mathrm{R}_{\mathrm{fir}} & \text { Irreversible Resistence } \\ \mathrm{R}_{\mathrm{fr}} & \text { Reversible Resistence } \\ \mathrm{R}_{\mathrm{M}} & \text { Intrinsic Membrane Resistance } \\ \mathrm{RO} & \text { Reverse Osmosis } \\ \mathrm{SEC} & \text { Specific Energy Consumption } \\ \mathrm{SPE} & \text { Solid Phase Extraction } \\ \mathrm{T} & \text { Temperature } \\ \mathrm{TOC} & \text { Total of Organic Carbon } \\ \mathrm{TSS} & \text { Total Suspend Solids } \\ \mathrm{W} & \text { Equivalent to the Permeate Pressure } \\ \text { WTP } & \text { Water Treatment Plant } \\ \text { WWTP } & \text { Waste Water Treatment Plant }\end{array}$




\section{INTRODUCTION}

\subsection{Contextualization and problem}

Over the past few years, there has been increasing concern about the occurrence and adverse effects of emerging pollutants. These pollutants are defined according to the Environmental Protection Agency (EPA) as new chemicals that have no current regulations on their maximum concentration disposal in environment. In addition, the negative impacts caused by these substances on nature and human health are still poorly understood (DEBLONDE et al., 2011; GARCIA-IVARS et al., 2017; EBELE; ABDALLAH \& HARRAD, 2017).

An extremely increasing presence of emerging pollutants and, pharmaceutical compoundsin particular, has been detected at trace concentration (ranging from ng/L up to $\mu \mathrm{g} / \mathrm{L}$ ) as free compounds and/or as metabolites in many environmental matrices worldwide, including drinking water supplies, wastewater effluents, soils and sediment (SANGION; GRAMATICA, 2016; EBELE; ABDALLAH \& HARRAD, 2017; GAFFNEYA et al., 2014; GROS, RODRÍGUEZ-MOZAZ \& BARCELÓ, 2013).

Pharmaceuticals are a large synthetic or natural group of substances that represent a several set of biologically active molecules designed to treating, curing and preventing diseases, thus improving the human and animal health (MINGUEZ et al., 2016; CAI et al., 2017). Among the classes that constitute the pharmaceutical group, highlight the anti-inflammatory, antibiotics, analgesics, lipid regulators, antidepressants, chemotherapy agents, contrasts, beta blockers and hormones. The constant increase in the consumption of these drugs is attributed to some factors, such as the development of new compounds for advanced treatment of diseases, population growth and the increased of life expectancy. Furthermore, the expiration of patents, thus providing generics that are less expensive, also contributes significantly to the expansion in the pharmaceuticals consumption (DAUGHTON, 2003). Due to these factors, is expected that the global drug consumption in 2020 will reach 4.5 trillion doses, representing an increase of $24 \%$ over 2015 . These values vary according to the level of economic development of the country, and the developing nations are the largest contributors to this growth (IMSI, 2015).

Programa de Pós-graduação em Saneamento, Meio Ambiente e Recursos Hídricos da UFMG 
The expansion of the consumption of these drugs contributes to the frequent pharmaceutical products occurrence in natural aquatic environments and effluents from wastewater treatment plants (WWTP). Pharmaceutical compounds are relatively stable and incompletely absorbed and metabolised by human and animal organism, thus resulting in non-absorbed and nonmetabolised portions which are disposed of in the environment through their excretions (urine and faeces) (TAHERAN et al., 2016; YAN et al., 2013; JELIC et al., 2011). The drugs are extremely resistant to biological degradation processes. The conventional wastewater treatment has a limited ability to remove pharmaceuticals and, generally, relevant part of these compounds pass intact by treatment stations and remaining biochemically active in the aquatic ecosystem (CHIFFRE et al.,2016; KASPRZYK-HORDERN et al., 2009; BOOKER et al.,2014; GAFFNEYA et al., 2014; WICK et al., 2009). Moreover, the concentrations of some pharmaceutical compounds have been found to increase during the wastewater treatment and this fact can occurs as a consequence of the elements conjugates back to the their parent compounds (WATTS et al., 2007). Therefore the WWTP, which is contemplated only by conventional sewage treatment, have been considered as hotspots for pharmaceutical products in the surface water (MICHAEL et al., 2013). Studies have also shown that pharmaceutical compounds found in raw water usually persist throughout the process used to treat drinking water (ZWIENER, 2007; KASPRZYK-HORDERN et al., 2009; WICK et al., 2009).

This problem has encouraged the expansion of scientific research on the possible impacts of these compounds on the ecosystem and on human health (BEBIANNO et al., 2016; SHAO et al., 2009). Extensive research on this topic began in the 1990s with the development of analytical methods, especially the mass spectrometer (MS) and high performance liquid chromatography (HPLC). These techniques allowed to separate, identify and quantify the drugs in concentrations of $\mathrm{ng} / \mathrm{L}$ or $\mu \mathrm{g} / \mathrm{L}$ in aquatic environments by analyzing the molecular structure and exact evaluations of the molar mass of the compounds present in the analyzed sample (LÖFFLER et al., 2005; GROS et al., 2012).

With the development of analytical methods for the detection of pharmaceuticals in the environment, especially in water bodies, and in the knowledge of the negative effects of these compounds on the ecosystem, the United States and the European Union (EU) are looking for extend the regulation and monitoring of these substances in nature (CUNHA et al., 2016). 
Brazil, however, does not yet have any type of regulation on the drugs occurrence in the aquatic environment. But, the Associação Brasileira de Engenharia Sanitária e Ambiental of the state of São Paulo (ABES/SP) published in 2012 a document called the Guide to Potability for Chemical Substances, which presents 291 priority substances not yet regulated by Brazilian legislation. In this guide were mentioned the occurrence of 14 pharmaceutical products in the Atibaia river and eight compounds in the Billings dam, but, no protocol for monitoring and control for these compounds has been established (UMBUZEIRO et al.,2012; CUNHA et al., 2016).

Nevertheless, Brazil presents an even worse scenario in relation to the developed countries. Approximately $17 \%$ of Brazilians, which corresponds to 35 million individuals, do not have access to drinking water. But the situation of sewage collection and treatment in the country is even more worrisome, since half of the population is not covered by sewage collection and only $42.67 \%$ of all effluent produced in Brazil is treated before it is released into the water bodies (INSTITUTO TRATA BRASIL, 2017). The conventional biological treatment of sewage is not sufficient to completely remove of the pharmaceutical compounds and the absence of such treatment contributes to aggravate the situation. This fact contributes to the pharmaceutical compounds occurrence in water intended for human consumption since the complete cycle of treatment of water is also not able to completely remove the pharmaceutical compounds (LIMA et al., 2014).

Thus, with the objective of improving the quality of water, especially which destined for human consumption, researches are being developed in the improvement of additional physico-chemical treatment technologies. Among of these technologies, the membrane separation processes (MSP) that combine the stability of operation with the excellent quality of the treated water, stands out (WEI et al., 2010; URTIAGA et al., 2013). Among the classical membranes separation processes, stand out the microfiltration (MF), ultrafiltration (UF), nanofiltration (NF) and reverse osmosis (RO) techniques, which use the pressure gradient as the driving force and these membranes differ mainly by size of its pores and, consequently, what it is able to reject. The characteristics of the effluent to be treated and the quality of the water to be obtained after membrane separation define which type of membrane to be used based on its selectivity. For the pharmaceutical compounds removal in aqueous

Programa de Pós-graduação em Saneamento, Meio Ambiente e Recursos Hídricos da UFMG 
matrices, the application of RO and NF membranes presents a good efficiency (URTIAGA, 2013).

The RO and NF are physical separation technologies that use a semipermeable membrane acting as a selective barrier, on which an external pressure is applied, causing the solution to cross the membrane retaining part of the constituents present in the solution (MALAEB \& AYOUB, 2011; MILLER, SHEMER \& SEMIAT, 2015; SHENVI, ISLOOR \& ISMAIL, 2015).

Thus, the membrane separation process including reverse osmosis and NF consists of two fluid streams which are separated through the membrane in e permeate that has a high quality, and in concentrate, which is the reject of the contaminants and other elements dissolved or not in the feed (BAKER, 2004; HABERT, BORGES \& NOBREGA, 2006). The processs cheme of both membranes with the division of fluid streams can be seen in Figure 1.

FIGURE 1: Scheme of membrane separation process

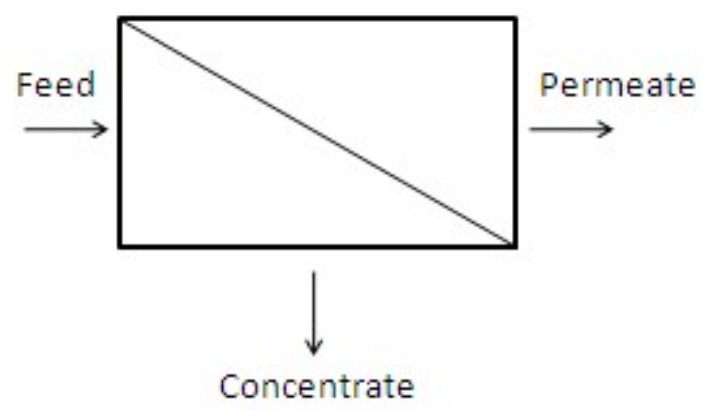

Some studies indicate that NF membranes provide higher permeability, however, it also presents lower rejection of monovalent ions $(<70 \%)$ than RO processes, but they offer a reasonable rejection of multivalent ions $(>99 \%)$ and organic matter $(>90 \%)$, whereasthe RO membrane presents high efficiency in the retention for all of these elements (TANG; CHONG \& FANE, 2011; AL MAMUN et al., 2017; RICHARDS, 2012). The NF membranes also differ from the RO membranes because they present larger molecular weight cut-off (MWCO), thus having a higher permeability to water, also presenting a lower pressure application to product the same flux when compared to the RO membrane (GEISE; PAUL \& FREEMAN, 2014; ZHAO et al., 2017). 
Furthermore, the performance of these membranes in the pharmaceutical compounds retention in water is also relevant and being evaluated in some studies, which point out better results for RO when compared to loose NF membranes, and similar efficiencies on tight NF membranes compared to RO membranes as can be seen in Table 1 (DOEDERER et al., 2014; KIMURA et al., 2003; RADJENOVIĆ et al., 2008; COMERTON et al., 2008; ZHAO et al., 2017).

TABLE 1: Retention percentage of some pharmaceutical products in aqueous matrices using $\mathrm{NF}$ and RO

\begin{tabular}{c|c|c|c}
\hline $\begin{array}{c}\text { Name of the } \\
\text { medicine }\end{array}$ & Carbamazepine & Diclofenac & Gemfibrozil \\
\hline Medicine group & Antiepileptic & $\begin{array}{c}\text { Anti- } \\
\text { inflammatory }\end{array}$ & Lipidregulator \\
\hline $\begin{array}{c}\text { Retention by } \\
\text { NF (\%) } *\end{array}$ & 99.3 & 97.2 & 99.8 \\
\hline $\begin{array}{c}\text { Retentionby } \\
\text { RO (\%) ** }\end{array}$ & 99.7 & 99.7 & 97.7 \\
\hline References & $\begin{array}{c}\text { HEBERER } \text { et } \\
\text { al., 2002** }\end{array}$ & $\begin{array}{c}\text { HEBERER et } \\
\text { al., 2002** }\end{array}$ & $\begin{array}{c}\text { COMERTON et } \\
\text { al., 2008** }\end{array}$ \\
\hline
\end{tabular}

* Bibliographic reference for the retention drug using NF

** Bibliographic reference for the retention drug using RO

The pharmaceutical compounds removal by the RO and NF membranes is accomplished through the interaction between the membrane and the contaminants, which can occur by size exclusion, electrostatic repulsion or adsorption (GEANIYU et al., 2015; TAHERAN et al., 2016). Some researches stand out that the efficiency in the charged pharmaceutical compounds retention varied from $89 \%$ to over $95 \%$ by NF membranes and can exceeded $95 \%$ by RO membranes (KIMURA et al., 2003; XU et al., 2006).

However, one of the major obstacles in the use of pressure driven membranes is the fouling. This fouling results in several detrimental effects on the efficiency of the process. Among these effects, it is worth noting the decrease in water production due to the flow decline. As a consequence of this drop in flow, it is necessary to increase the pressure applied as the driving force, to obtain the same rate of water production. In addition, fouling also contributes to the 
gradual degradation of the membrane thereby decreasing the quality of the permeate producted and the membrane life span (NG \& ELIMELECH, 2004). Fouling can be formed by the adsorption processes (BANERJEE \& DE, 2010), pore blocked (MATTARAJ et al., 2011) and cake formation (HOEK \& ELIMELECH, 2003). According to Couto, Moravia and Amaral (2017), permeate flow is one of the most important operational parameters for the RO and NF application, because it represents the water production of the system, consequently, affecting the economic feasibility of the use of these membranes in real scale.

Some researches suggest the association of the pharmaceutical compounds with the organic matter, present in the natural aqueous matrices, can contribute with these compounds rejection in the NF process. This is because this association allows the solute particles to bind by increasing the size of the compound, thus making them larger than the membrane cut-off point (HU; JIN \& ONG, 2007; COMERTON; ANDREWS \& BAGLEY, 2009; PLAKAS; et al., 2006; SADMANI; ANDREWS \& BAGLEY, 2014.). According to Verliefde et al (2009), the presence of colloidal solutes contributes to the effect of concentration polarization which may provide an increase in the negatively charged pharmaceuticals rejection. This fact occurs due to electrostatic repulsion of the solutes accumulated on the surface of the membrane with the negatively charged compounds present in the water.

In this context, this study aims to evaluate the pharmaceutical compounds removalfrom real representative surface water by NF and RO processes. This evaluation was carried out using the Doce river raw and treated water, because it is necessary to understand how the occurrence of the pharmaceutical compounds happens in natural aqueous matrices. In this way, it was possible to analyze a real scenario and how the solutes, that are present in natural waters, may interfer in the membrane separation processes that were evaluated in this study.

Programa de Pós-graduação em Saneamento, Meio Ambiente e Recursos Hídricos da UFMG 


\subsection{Justification}

The concern about the pharmaceutical compounds occurrencein natural waters is crescent. The United States of America (USA) and the Union Europe (EU) are establishing guidelines and standards on monitoring and controlling the maximum concentration of pharmaceuticals in aqueous matrices in the environment. This concern is growing and influencing developing countries, how is the case of Brazil. However, the lack of studies on the drugs occurrence from raw and treated water from a river and not from synthetic samples compromises the development of such legislation. In this way, the present study can contribute by demonstrating how this contamination occurs in a real scenario.

With the development of standards that control the occurrence of pharmaceuticals in aqueous matrices in the USA and the EU, it is possible to see the progress in research about the efficiency and feasibility of complementary treatments for compliance with these guidelines in some developed countries. Most of developing countries presents a deficit on the efficiency and viability of these complementary treatments aiming at the the pharmaceutical compounds retention, mainly in relation to the membrane separation process (MSP). Nevertheless, it is necessary to study viable alternatives to meet future legislation that will contemplate the control of this type of micro pollutant in water bodies and, consequently, to reduce its negative impacts on the environment.

Thus, this study can contribute to the evaluation of the efficiency about the application of NF and $\mathrm{RO}$ membranes for the pharmaceutical products retention in the real aqueous matrices by evaluating their technical viability.

Programa de Pós-graduação em Saneamento, Meio Ambiente e Recursos Hídricos da UFMG 


\subsection{Objectives}

\subsubsection{General}

Evaluate the pharmaceutical compounds removal from real representative surface water by nanofiltration and reverse osmosis processes.

\subsubsection{Specifics}

- Identify and quantify the most recurrent pharmaceutical compounds in raw and treated water by the Central Water Treatment Plant (WTP) of Governador Valadares, Minas Gerais;

- Evaluate and compare the efficiency of the drugs removal that were present in the Doce river raw water using $\mathrm{NF}$ and $\mathrm{RO}$, regarding pecific energy consumption for each membrane tested.

- To compare the performance of the membrane selected in relation to the complete water system treatment in operation in Governador Valadares city in terms of the pharmaceutical compounds removal found in the Doce river raw water.

- To evaluate the effect of transmembrane pressure and feed flow on the pharmaceutical compounds retention and on the membrane general performance. 


\subsection{Structural form}

Besides this introduction (Chapter 2 and the final considerations Chapter 5), this dissertation is structured in three chapters in an article format. The choice of an article format indicates that the chapters are interdependent and can be read separately.

Chapter 2 is about the evaluation of pharmaceutical compounds occurrencein the surface water of the aqueous matrix chosen to be worked (Doce river) and these compounds occurrence in drinking water that has as manacial the same surface water collect point.

The third chapter is about the evaluation of NF and RO considering the efficiency of each one in regarding to permeate flux, its physico-chemical quality, specific energy consumption for each MSP operation and the pharmaceuticals compounds removal.

After the choice of membrane, from Chapter three, the $4^{\text {th }}$ chapter contemplates the evaluation of the transmembrane pressure effect, and feed flow rate on the pharmaceutical compounds retention, as well as on the membrane general performance.

This study stage was carried out using the membrane selected from the Chapter 3 and the best transmembrane pressure and feed flow rate indicated in the Chapter 4 . In addition, the performance of NF and the conventional water treatment system in operation in the Governador Valadares city were compared in terms of pharmaceutical compounds removal.

Programa de Pós-graduação em Saneamento, Meio Ambiente e Recursos Hídricos da UFMG 


\subsection{References}

AL MAMUN,A.M.D;BHATTACHARJEE, S; PERNITSKY,D; SADRZADEH, M. Colloidal fouling of nanofiltration membranes: development of a standard operating procedure. Membranes, 2017.

BAKER, R.W. Membrane technology and applications, 2. Ed. John Wiley \& Sons Ltd, England, 2004.

BANERJEE, P; DE, S. Steady state modeling of concentration polarization including adsorption during nanofiltration of dye solution. Sep. Purif. Technol, v. 71, p. 128-135, 2010.

BEBIANNO, M. J; SRODA, S; GOMES, T; CHAN, P; BONNAFE, E; BUDZINSKI, H; GERET, F. Proteomic changes in Corbicula fluminea exposed to wastewater from a psychiatric hospital. Environmental Science Pollution, v. 23, p. 5046-5055, 2016.

BOOKER, V; HALSALL, C; LLEWELLYN, N; JOHNSON, A; WILLIAMS, R. Prioritising anticancer drugs for environmental monitoring and risk assessment purposes, Science of the Total Environment, v. 474, p. 159-170, 2014.

CAI, Z; DWIVEDI, A. D; LEE, W; ZHAO, X; LIU, W; SILLANPÄÄ, M; ZHAO, D; HUANG, C ; FU, J. Application of nanotechnologies for removing pharmaceutically active compounds in water: Development and future trends.Environmental Science Nano, p.2-22, 2017.

CHIFFRE, A; CLÉRANDEAU, C; DWOINIKOFF, C; LE BIHANIC, F; BUDZINSKI, H; GERET, F; CACHOT, J. Psychotropic drugs in mixture alter swimming behaviour of Japanese medaka (Oryziaslatipes) larva eabove environmental concentrations. Environmental Science Pollution, v. 23, p. 4964 - 4977, 2016.

COMERTON, A.M; ANDREWS, R.C; BAGLEY, D.M; HAO, C. The rejection of endocrine disrupting and pharmaceutically active compounds by NF and RO membranes as afunction of compound and water matrix properties. Journal of Membrane Science, v. 313,p. 323335,2008 .

COMERTON, A.M; ANDREWS, R.C; BAGLEY, D.M.The influence of natural organic matter and cations on the rejection of endocrine disrupting and pharmaceutically active compounds by nanofiltration, Water Res.v. 43, p. 613-622, 2009.

COUTO,C. F; MORAVIA,W.G.; AMARAL,M. C. S. Integration of microfiltration and nanofiltration to promote textile effluent reuse, Clean Techn Environ Policy, 2017.

CUNHA, D. L; SILVA, S. M. C; BILA, D. M; OLIVEIRA, J.L.M;SARCINELLI,P.N;LARENTIS,A.L. Regulamentação do estrogênio sintético $17 \alpha-$ etinilestradiol em matrizes aquáticas na Europa, Estados Unidos e Brasil. Cadernos de Saúde Pública, v. 32, n. 3, p. 1-13, 2016. 
DAUGHTON, C. G. Cradle-to-cradle stewardship of drugs for minimizing their environmental disposition while promoting human health. I. Rational for and avenues toward a Green pharmacy. Environ Health Perspect, v. 111, p. 757 - 774, 2003.

DEBLONDE, T; COSSU-LEGUILLE, C; HARTEMANN, P. Emerging pollutants in wastewater: a review of the literature. Int. J. Hyg. Environ. Health, v. 214,p.442-448, 2011.

DOEDERER, K; FARRÉ, M. J; PIDOU, M; WEINBERG, H, S; GERNJAK W. Rejection of disinfection by-products by RO and NF membranes: influence of solute properties and operational parameters. Journal of Membrane Science, v.467, p.195-205, 2014.

EBELE, A. J, ABDALLAH, M,A.E; HARRAD, S. Pharmaceuticals and personal care products (PPCPs) in the freshwater aquatic environment.EmergingContaminants, p. 1-16, 2017.

GAFFNEYA, V. J; CARDOSO, V. V; RODRIGUES, A; FERREIRA, E; BENOLIEL, M. J; ALMEIDA, C. M. M. Análise de Fármacos em Águas por SPE-UPLC-ESI-MS/MS, Quim. Nova, V. 37, p. 138-149, 2014.

GARCIA-IVARS J; DURÁ-MARÍA J;MOSCARDÓ-CARREÑO C; CARBONELLALCAINA C; ALCAINA-MIRANDA, MI; IBORRA-CLAR, MI. Rejection of trace pharmaceutically active compounds present in municipal wastewaters using ceramic fine ultrafiltration membranes: Effect of feed solution $\mathrm{pH}$ and fouling phenomena. Separation and Purification Technology, v. 175, p. 58-71, 2017.

GEANIYU, S.O; HULLEBUSCH, E.D.V; CRETIN, M; ESPOSITO, G; OTURAN, M.A. Coupling of membrane filtration and advanced oxidation processes for removal of pharmaceutical residues: a critical review. Sep. Purif. Technol v. 156, p. 891-914, 2015.

GEISE, G. M; PAUL, D .R; FREEMAN, B. D. Fundamental water and salt transport properties of polymeric materials. Progress in Polymer Science, v. 39, p. 1-42, 2014.

GROS,M; RODRÍGUEZ-MOZAZ,S;BARCELÓ,D. Fast and comprehensive multi-residue analysis of a broad range of human and veterinary pharmaceuticals and some of their metabolites in surface and treated waters by ultra-high-performance liquid chromatography coupled to quadrupole-linear ion trap tandem mass spectrometry. Journal of Chromatography $A$, v.1248, p. 104-121, 2012.

GROS,M; RODRÍGUEZ-MOZAZ,S;BARCELÓ,D. Rapid analysis of multiclass antibiotic residues and some of their metabolites in hospital, urban wastewater and river water by ultrahigh-performance liquid chromatography coupled to quadrupole-linear ion trap tandem mass spectrometry. JournalofChromatography A, v.1292, p. 173-188, 2013.

HABERT, A. C., BORGES, C. P., NOBREGA, R. Processos de Separação por Membranas. Rio de Janeiro: E-papers, 2006. 
HEBERER, T; FELDMANN, D; REDDERSEN, K; ALTMANN, H.J; ZIMMERMANN, T. Production of drinking water fromhighly contaminated surfacewaters: removal of organic, inorganic, and microbial contaminants applying mobile membrane filtration units.Acta Hydrochim. Hydrobiol, v.30,p. 24-33, 2002.

HOEK, E.M.V; ELIMELECH, M. Cake-enhanced concentration polarization: A new fouling mechanism for salt-rejecting membranes. Environ. Sci. Technol, v. 37, p. 5581-5588, 2003.

HU, J.Y; JIN. X.; ONG, S.L. Rejection of estrone by nanofiltration: influence of solution chemistry, J. Membr. Sci.v. 302, p. 188-196, 2007.

IMS INSTITUTE (IMSI). The Global Use of Medicines: Outlook Through 2020. 3 p. 2015. Available at: < www.iqvia.com/-/media/iqvia/pdfs/institute-reports/global-medicines-use-in2020.pdf?la=en\&hash=5B21DDFF1C339013F046FA2CA498CCADB521A8F3>. Accessed in May, 18 of 2016.

INSTITUTO TRATA BRASIL. Saneamento no Brasil. Available at: http://www.tratabrasil.org.br/saneamentono-brasil. Accessed in May of 2017.

JELIC, A.; GROS, M; GINEBREDA, A; CESPEDES-SÁNCHEZ, R,; VENTURA, F.; PETROVIC, M.; BARCELO, D. Occurrence, partition and removal of pharmaceuticals in sewage water and sludge during wastewater treatment. Water Research, v. 45, p.1165-1176, 2011.

KASPRZYK-HORDERN， B; DINSDALE， R. M; GUWY， A. J.The removal of pharmaceuticals, personal care products, endocrine disruptors and illicit drugs during wastewater treatment and its impact on the quality of receiving waters. Water Research, v. 43, p. 363-380, 2009.

KIMURA, K; AMY, G; DREWES, J. E; HEBERER, T; KIM, T .U; WATANABE, Y. Rejection of organic micropollutants (disinfection by-products, endocrine disrupting compounds, and pharmaceutically active compounds) by NF/RO membranes. JournalofMembrane Science, v. 227,p. 113-121, 2003.

LIMA.D. R. S;ROBSON, J. C. F. A; LIBÂNIO.M; AQUINOA S.F. Avaliação da remoção de fármacos e de desreguladores endócrinos em águas de abastecimento por clarificação em escala de bancada. Quim.Nova, v. 37, p. 783-788, 2014.

LÖFFLER, D; OMBKE, J. R; MELLER, M ;TERNES,T.A. Environmental fate of pharmaceuticals in water/sediment systems. Environmental Science Technology, v. 39, p. 5209-5218, 2005.

MALAEB, L; AYOUB, G.M.Reverse osmosis technology for water treatment: state of the art review. Desalination, v.267, p.1-8, 2011.

MATTARAJ, S; JARUSUTTHIRAK, C; CHAROENSUK, C.; JIRARATANANON, R. A combined pore blockage, osmotic pressure, and cake filtration model for crossflow

Programa de Pós-graduação em Saneamento, Meio Ambiente e Recursos Hídricos da UFMG 
nanofiltration of natural organic matter and inorganic salts, Desalination, v. 274, p. 182191,2011 .

MILLER, S; SHEMER, H; SEMIAT, R, Energy and environmental issues in desalination. Desalination, v.366, p. 2-8, 2015.

MINGUEZ, L; PEDELUCQ, J;FARCY, E; BALLANDONNE, C; BUDZINSKI.H; MARIEPIERRE, H.L. Toxicities of 48 pharmaceuticals and their freshwater and marine environmental assessment in northwestern France. Environmental Science Pollution,v.23, p. $4992-5001,2016$.

NG, H. Y; ELIMELECH, Influence of colloidal fouling on rejection of trace organic contaminants by reverse osmosis. Journal of Membrane Science, v. 244, p. 215-226, 2004.

PLAKAS, K.V; KARABELAS, A.J; WINTGENS, T; MELIN, T. A study of selected herbicides retention by nanofiltration membranes - the role of organic fouling, J. Membr. Sci.v. 284, p. 291-300, 2006.

RADJENOVIC, J: PETROVIC, M; VENTURA, F; BARCELO, D. Rejection of pharmaceuticals in nanofiltration and reverse osmosis membrane drinking water treatment. Water Research, v. 42,p. 3601-3610, 2008.

RICHARDS, L. A.The removal of inorganic contaminants using nanofiltration and reverse osmosis, 2012. Doctoral dissertation, Heriot-Watt University

SADMANI, A. A; ANDREWS, R. C; BAGLEY, D. M. Impact of natural water colloids and cations on the rejection of pharmaceutically active and endocrine disrupting compounds by nanofiltration. Journal of Membrane Science, v. 450, p. 272-281, 2014.

SANGION, A; GRAMATICA, P.Hazard of pharmaceuticals for aquatic environment: Prioritization by structural approaches and prediction of ecotoxicity. Environment International,v.3423,p. 1-13,2016.

SHAO,B.;CHEN, D., ZHANG, J., WU, Y., SUN, C. Determination of 76 pharmaceutical drugs by liquid chromatography-tandem mass spectrometry in slaughter house waste water. Journal of ChromatographyA, v. 1216, p. 8312-8318, 2009.

SHENVI ,S.S; ISLOOR,S; ARUN, M; AHMAD,I. F; SIMON, J; AMIR,A.A. Humic acid based biopolymeric membrane for effective removal of methylene blue and rhodamine B, Industrial and Engineering Chemistry Research, v.54, p. 4965-4975, 2015.

TAHERAN, M; BRAR, S. K; VERMA, M; SURAMPALLI, R.Y; ZHANG, T.C; VALERO, J.R. Membrane processes for removal of pharmaceutically active compounds (PhACs) from water and wastewaters. Science of the Total Environment,v.547,p.60-77,2016.

TANG, C.Y; CHONG, T.H; FANE, A.G. Colloidal interactions and fouling of NF and RO membranes: A review. Adv. Colloid Interface Sci, v. 164, p. 126-143,2011.

Programa de Pós-graduação em Saneamento, Meio Ambiente e Recursos Hídricos da UFMG 
UMBUZEIRO, G. A; GONÇALVES, C; KUMMROW, F; MIRANDA, J. D; PEDROZO, M. F. M; MATTA, M. E. M; ROQUETTI, M. H; SILVÉRIO, P. F.; HANNA, R. A; SOUZA, R. M. G. L; KUNO, R; TAKEDA, S. H. K; CAMPOS, S. V.Guia de potabilidade para as substâncias químicas. São Paulo: ABES, 2012.

URTIAGA, A.M; PÉREZ,G; IBÁÑEZ,R;ORTIZ,I. Removal of pharmaceuticals from a WWTP secondary effluent by ultrafiltration/reverse osmosis followed by electrochemical oxidation of the RO concentrate. Dasalination, v.331, p. 26-34, 2013.

VERLIEFDE, A. R;CORNELISSEN, E. R; HEIJMAN, S. G. J; PETRINIC, I; LUXBACHER, T; AMY, G. L; VAN DIJK, J. C. Influence of membrane fouling by (pretreated) surface water on rejection of pharmaceutically active compounds (PhACs) by nanofiltration membranes. Journal of Membrane Science, v. 330, p.90-103, 2009.

WATTS, C; MAYCOCK, D; CRANE, M; FAWELL, J; GOSLAN, E. Desk Based Review of Current Knowledge on Pharmaceuticals in Drinking Water and Estimation of Potential Levels and Final Report. Defra Project Code: CSA 7184/WT02046/ DWI70/2/213, 2007.

WEI, X.; WANG, Z; FAN, F; WANG, J., WANG, S. Advanced treatment of a complex pharmaceutical wastewater by nanofiltration: membrane foulant identification and cleaning. Desalination ,v.251,p. 167-175, 2010.

WICK, A; FINK, G; JOSS, A; SIEGRIST, H; TERNES, T.A. Fate of beta blockers and psycho-active drugs in conventional wastewater treatment. Water Research, v. 43,p. 1060 1074, 2009.

XU, P; DREWES, J.E; KIM, T.-U; BELLONA, C; AMY, G. Effect of membrane fouling on transport of organic contaminants in NF/RO membrane applications. Journal of Membrane Science, v. 279, p. 165-175, 2006.

YAN, Q; GAO,X; CHEN,Y; PENG, X; ZHANG, Y; GAN, X; ZI, C; GUO, J. Occurrence, fate and ecotoxicological assessment of pharmaceutically active compounds in wastewater and sludge from wastewater treatment plants in Chongqing, the Three Gorges Reservoir Area.Science of the Total Environment, v. 470, p.613-630,2013.

ZHAO, Y; KONG, F; WANG, Z; YANG; H, WANG; YUEFENG; F; XIE, T; DAVID W. Role of membrane and compound properties in affecting the rejection of pharmaceuticals by different RO/NF membranes, Environ. Sci. Eng, v.11,p.6-20, 2017.

ZWIENER, C. Occurrence and analysis of pharmaceuticals and their transformation products in drinking water treatment. Anal. Bioanal. Chem, v.387, p.1159-1162, 2007. 


\section{EVALUATION OF THE PHARMACEUTICAL COMPOUNDS OCCURRENCE IN THE DOCE RIVER RAW AND TREATED WATER}

\subsection{Introduction}

Pharmaceutical products are becoming increasingly prevalent in various compartments of the aquatic environment, such as surface water and sewage, in concentrations capable of causing harmful effects on aquatic organisms (BRODIN et al., 2014; NIKOLAOU, MERIC, FATTA, 2007; EBELE, ABDALLAH \& HARRAD, 2017). Medicines are considered to be pseudopersistent pollutants because they are frequently entering the environment since they are widely marketed (GOGOI et al., 2018). According to Kummerer (2010), more than 160 different pharmaceutical compounds have been detected in aqueous matrices at concentrations of ng $/ \mathrm{L}$ to $\mu \mathrm{g} / \mathrm{L}$.

According to Jelic et al (2011), after the drug is ingested, the medicine goes through metabolic processes in the body and significant fractions of the parent compound are excreted through the faeces and urine in the non-metabolized form or as metabolites, followed by the sewage collection network to the waste water treatment plant (WWTP), or directly in a water body without previous treatment as is the case of the Governador Valadares city, until now, which is located in the state of Minas Gerais, Brazil.

Governador Valadares is the largest municipality in the mesoregion where it is located. Despite having approximately 300 thousand inhabitants in the urban area, according to the SNIS (2014), whose data can be observed in Table 2, the city does not present sewage treatment systems, in this way, all the effluent productedin the municipality is discharched to the river that supplies the region.

TABLE 2: Indicators of water, sewage and sewage treated by water consumed in Governador Valadares - MG

\begin{tabular}{c|c|c|c}
\hline $\begin{array}{c}\text { Total population } \\
\text { (IBGE 2014) }\end{array}$ & $\begin{array}{c}\text { Indicator of } \\
\text { urban water } \\
\text { service (\%) }\end{array}$ & $\begin{array}{c}\text { Indicator of urban } \\
\text { sewage service } \\
(\%)\end{array}$ & $\begin{array}{c}\text { Indicator of wastewater } \\
\text { treated by water consumed } \\
(\%)\end{array}$ \\
\hline 276.995 & 99.6 & 97.7 & 0.0 \\
\hline
\end{tabular}

Reference: SNIS (2014).

Programa de Pós-graduação em Saneamento, Meio Ambiente e Recursos Hídricos da UFMG 
As can be seen in Table 2, the urban water service supply is about $99.60 \%$, which around of $70 \%$ of this service is responsibility of the Central Water Treatment Plant (WTP) of the Governador Valadares.

In Brazil is predominant the water treatment complete cycle which comprising the steps of coagulation, flocculation, decantation, filtration, and disinfection (LIMA et al., 2014). Nevertheless, this type of treatment is also inefficient in the complete pharmaceutical compounds removal, since these WTPs are designed to carry out high particulate materialremoval, microorganism and other parameters established by Ordinance $\mathrm{N}^{\circ} .2914$ of 2011, which does not contemplate standards limits for the pharmaceutical compounds occurrence in drinking water (LIMA et al., 2014).

Although conventional water treatment is not effective for complete pharmaceutical products removal, some steps in such treatment can achieves significantly decrease of the concentration of some pharmaceuticals in potable water. In the case of Governador Valadares, Central WTP makes the capture of the Doce river raw water, which is one of the largest and most important rivers in the southeastern region of Brazil (AGÊNCIA NACIONAL DAS ÁGUAS, 2015). The the Doce river water quality is monitored by the Instituto Mineiro de Gestão das Águas (IGAM). The water quality of this source is regulated by the Resolution of the Conselho Nacional de Meio Ambiente (CONAMA) - 357/2005 as class 2, that is, it can be destined for human consumption as long as it is treated by a complete cycle treatment (SAAEGOVAL, 2016).

It is important to note that on November 5, 2015, the Samarco mine dam tailings, that located in the district of Bento Rodrigues, Minas Gerais, broke off. This rupture made with the mud reached the Doce river compromising for some days the quality of the water. Thus, the Central WTP probably operated using a greater amount of coagulant, chlorine among other chemical compounds to guarantee the quality of treated water in accordance with Ordinance $2914 / 2011$.

In this context, this study aims to identify and quantify the most recurrent pharmaceutical compounds in raw and treated water by the Central WTP of Governador Valadares which is 
contemplated by the following steps: Coagulation, flocculation, decantation, filtration and disinfection by chlorine.

\subsection{Materials and methods}

\subsubsection{Water sources}

Collects were performed at the same catchment point that Central WTP of the Governador Valadares uses to obtain the Doce river raw water, that will be treated of human consumption. This catchment point geographic coordinate is: $18^{\circ} 51^{\prime} 50.045$ "S and $41^{\circ} 56^{\prime} 46.86^{\prime \prime} \mathrm{W}$. The treated water was collected after the disinfection by chlorine in the Central WTP, that geographical coordinate is: $18^{\circ} 51^{\prime} 47.83$ " S and $41^{\circ} 56^{\prime} 47.02 " \mathrm{~W}$. The period of collects was established in April 2016 to April 2017 covering a hydrological year. The collects were carried out every three months, as can be seen in Table 3 .

TABLE 3: Schedule of the colletc of the raw and treated water from the Doce river

\begin{tabular}{c|c}
\hline Collect & Collectiondate \\
\hline Sample 1 & April 2016 \\
Sample 2 & July 2016 \\
Sample 3 & November 2016 \\
Sample 4 & January 2017 \\
Sample 5 & April 2017 \\
\hline
\end{tabular}

The volume collected in each collection was $20 \mathrm{~L}$ of raw water and 5L of treated water, which were stored in polyethylene bottles previously cleaned with the acid bath of $10 \% \mathrm{HCl}$, then rinsed with deionized water. During the journey between Governador Valadares to the Universidade Federal de Minas Gerais (UFMG), the samples were protected from sunlight. As soon as the samples arrived at UFMG, they were stored in the cold camera at $5^{\circ} \mathrm{C}$, located in Departamento de Engenharia Sanitária e Ambiental (DESA), until extraction and analytical analyzes (normally, within 2 days after arrival).

\subsubsection{Pharmaceutical compounds identification}

The identification of the drugs started with the solid phase extraction step (SPE), whose first stage is the filtration of $1 \mathrm{~L}$ of the sample in hydrophilic PVDF filter of $0.45 \mu \mathrm{m}$. Then, the Aspec Gilson GX-271 Liquid Handler is used so that this volume, already filtered, passed in a

Programa de Pós-graduação em Saneamento, Meio Ambiente e Recursos Hídricos da UFMG 
constant flow of $5 \mathrm{~mL} / \mathrm{min}$ by the $\mathrm{C} 18 / 18 \%$ cartridge (500 $\mathrm{mg} / 6 \mathrm{~mL}$ - Applied Separations), previously conditioned with $5 \mathrm{~mL}$ of methanol and $5 \mathrm{~mL}$ of ultra pure water.

The extraction was carried out in two distinct phases, firstly without $\mathrm{pH}$ adjustment ( $\mathrm{pH}$ 7) and then with $\mathrm{pH}$ adjustment to 2 by adding 0.002 mols $/ \mathrm{L}_{2} \mathrm{SO}_{4}$ solution. After this extraction of analytes of interest, the cartridges were eluted using $2 \times 4 \mathrm{~mL}$ of methanol.

An aliquot of this elution is infused directly into the Shimadzu brand HPIM equipment, model Prominence DGU / 20A3, coupled to the Bruker brand micrOTOF-QII mass spectrometer installed in the DESA / UFMG Laboratory of Mass Spectrometry. With this initial evaluation of the drug scanning, it was possible to detect the probable pharmaceutical compounds comparing the molar masses of solutes present in the samples with the masses of 87 drugs contemplated in the project "Avaliação da ocorrência de fármacos na água para consume humano: subsídios para a inserção no padrão de potabilidade brasileiro", a partnership of the Fundação Nacional da Saúde (FUNASA) with DESA / UFMG, which this study is part of. In addition, the choice these elements for quantification took into consideration the acquisition price of the analytical standards. The most recurrent pharmaceutical compounds, among these 87 drugs in the Funasa project list that were identified in the sample of Doce river raw water were analyzed in this study and can be seen in Table 4.

Programa de Pós-graduação em Saneamento, Meio Ambiente e Recursos Hídricos da UFMG 
TABLE 4: The most recurrent pharmaceutical compounds in the Doce river raw water, collected in April 2016, that were detected in the preliminary analysis of full scan using the mass spectrometer

\begin{tabular}{c|c|c|c|c|c|c}
\hline ChemicalGroup & Medicine & $\begin{array}{c}\text { Molecular } \\
\text { formula }\end{array}$ & CAS number & $\begin{array}{c}\text { Molecular Weight } \\
\text { (g/mol) }\end{array}$ & Log Kow & pKa \\
\hline$\beta$-Blockers & Atenolol & $\mathrm{C}_{14} \mathrm{H}_{22} \mathrm{~N}_{2} \mathrm{O}_{3}$ & $29122-68-7$ & 267.17 & 0.16 & 9.60 \\
\hline \multirow{2}{*}{$\begin{array}{c}\text { Analgesicsandanti- } \\
\text { inflammatories }\end{array}$} & Betamethasone & $\mathrm{C}_{22} \mathrm{H}_{29} \mathrm{FO}_{5}$ & $378-44-9$ & 393.20 & 1.94 & 12.42 \\
\cline { 2 - 7 } & Phenazone & $\mathrm{C}_{11} \mathrm{H}_{12} \mathrm{~N}_{2} \mathrm{O}$ & $60-80-0$ & 189.10 & 0.38 & 1.40 \\
\cline { 2 - 7 } & Phenylbutazone & $\mathrm{C}_{19} \mathrm{H}_{20} \mathrm{~N}_{2} \mathrm{O}_{2}$ & $50-33-9$ & 309.16 & 3.16 & 4.50 \\
\hline \multirow{3}{*}{ Antiallergic } & Cimetidine & $\mathrm{C}_{10} \mathrm{H}_{16} \mathrm{~N}_{6} \mathrm{~S}$ & $51481-61-9$ & 252.11 & 0.40 & 6.80 \\
\cline { 2 - 7 } & Loratadine & $\mathrm{C}_{22} \mathrm{H}_{23} \mathrm{ClN}_{2} \mathrm{O}_{2}$ & $79794-75-5$ & 382.14 & 5.20 & 4.40 \\
\cline { 2 - 7 } & Ranitidine & $\mathrm{C}_{13} \mathrm{H}_{22} \mathrm{~N}_{4} \mathrm{O}_{3} \mathrm{~S}$ & $66357-35-5$ & 314.14 & 0.27 & 8.00 \\
\hline \multirow{2}{*}{ Antiulcerous } & Scopolamine & $\mathrm{C}_{17} \mathrm{H}_{21} \mathrm{NO}_{4}$ & $51-34-3$ & 303.14 & 0.98 & 7.75 \\
\cline { 2 - 8 } & Omeoprazole & $\mathrm{C}_{17} \mathrm{H}_{19} \mathrm{~N}_{3} \mathrm{O}_{3} \mathrm{~S}$ & $73590-58-6$ & 345.11 & 2.23 & 7.40 \\
\hline Antifungal & Fluconazole & $\mathrm{C}_{13} \mathrm{H}_{12} \mathrm{~F}_{2} \mathrm{~N}_{6} \mathrm{O}$ & $86386-73-4$ & 306.10 & 0.40 & 12.71 \\
\hline Antidepressants & Paroxetine & $\mathrm{C}_{19} \mathrm{H}_{20} \mathrm{NFO}_{3}$ & $61869-08-7$ & 329.14 & 1.23 & 9.60 \\
\hline Immunosuppressive & Prednisone & $\mathrm{C}_{21} \mathrm{H}_{26} \mathrm{O}_{5}$ & $53-03-2$ & 358.17 & 1.46 & 12.58 \\
\hline \multirow{2}{*}{$\begin{array}{c}\text { Lipid and Cholesterol } \\
\text { Regulators }\end{array}$} & Fenofibrate & $\mathrm{C}_{20} \mathrm{H}_{21} \mathrm{ClO}_{4}$ & $49562-28-9$ & 361.12 & 5.19 & 4.90 \\
\hline \multirow{2}{*}{ Antibiotics } & Trimeteroprin & $\mathrm{C}_{14} \mathrm{H}_{18} \mathrm{~N}_{4} \mathrm{O}_{3}$ & $738-70-5$ & 291.14 & 0.91 & 7.20 \\
\cline { 2 - 7 } & Erythromycin & $\mathrm{C}_{37} \mathrm{H}_{67} \mathrm{NO}_{13}$ & $114-07-8$ & 734.47 & 3.06 & 8.90 \\
\cline { 2 - 7 } & Clarithromycin & $\mathrm{C}_{38} \mathrm{H}_{69} \mathrm{NO}_{13}$ & $81103-11-9$ & 748.48 & 3.16 & 8.99 \\
\hline
\end{tabular}

Reference: PUBCHEM, 2017.

Programa de Pós-graduação em Saneamento, Meio Ambiente e Recursos Hídricos da UFMG 
With these standards, the infusions will be redone, with the same procedure described previously, for the chromatographic quantification of the drugs in each sample. An aliquot of this elution is infused directly into the mass spectrometry (MS) micrOTOF-QII Bruker installed in the DESA/UFMG Laboratory of Mass Spectrometry. After this preliminary analysis of the possible drugs present in each sample, the analytical standards for the most recurrent drugs were acquired with high purity (>99\%) of Sigma Aldrich. After this HPLC equipment (Shimadzu model Prominence DGU/20A3) was coupled to the micrOTOF-QII mass spectrometer (Bruker) to quantify and confirm the possible drugs in each sample. In the step, the calibration curves wereconstructed containing 14 points for each possible drug with a concentration ranging from $10 \mathrm{ng} / \mathrm{L}$ to $8 \mu \mathrm{g} / \mathrm{L}$. The method detectation limits (MDL) and method quantification limit (MQL) were determined, with the concentration of analyte with signal-to-noise ratio of 3 and 10, respectively. The quantification of pharmaceutical compounds was performed using the chromatrographic conditions described in Table 5.

TABLE 5: Chromatrographic conditions for the quantification of the pharmaceutical compounds in the HPLC coupled to the mass spectrometer

\begin{tabular}{ll}
\hline Parameter & Method \\
\hline Injection volume & $10 \mu \mathrm{L}$ \\
Flow rate & $0.1 \mathrm{~mL} / \mathrm{min}$ \\
& $\begin{array}{l}0.1 \% \text { of formic acid in water } \\
\text { Compositionof mobile phase }\end{array}$ \\
Mobile phase concentration gradient program & $\begin{array}{l}\text { Isocratic }-95 \% \mathrm{~B} \\
\text { Total Analysis Time }\end{array}$ \\
\hline
\end{tabular}

\subsection{Results}

The results of the pharmaceutical products occurrence in the Doce river raw water and the water treated by the WTP Central of Governador Valadares can be seen in Table 6. 
TABLE 6: Evaluation of the presence of pharmaceutical compounds in the raw and treated water in the Central WTP of Governador Valadares

\begin{tabular}{c|c|c|c|c|c|c|c|c}
\hline \multirow{2}{*}{$\begin{array}{c}\text { Pharmaceutical } \\
\text { compounds }\end{array}$} & \multicolumn{4}{|c|}{ Surface water } & \multicolumn{4}{c}{ Potable water } \\
\cline { 2 - 10 } & $\begin{array}{c}\mathrm{FO} \\
\mathrm{N}=5)\end{array}$ & $\mathrm{C}(\mathrm{ng} / \mathrm{L})$ min-max & $\begin{array}{c}\mathrm{C}(\mathrm{ng} / \mathrm{L}) \\
\text { average }\end{array}$ & $\begin{array}{c}\mathrm{C}(\mathrm{ng} / \mathrm{L}) \\
\text { median }\end{array}$ & $\begin{array}{c}\mathrm{FO} \\
(\mathrm{N}=5)\end{array}$ & $\mathrm{C}(\mathrm{ng} / \mathrm{L}) \min -\mathrm{max}$ & $\begin{array}{c}\mathrm{C}(\mathrm{ng} / \mathrm{L}) \\
\text { average }\end{array}$ & $\begin{array}{c}\mathrm{C}(\mathrm{ng} / \mathrm{L}) \\
\text { median }\end{array}$ \\
\hline Betamethasone & 4 & $20.00-701.04$ & 246.17 & 131.64 & 0 & $<\mathrm{MDL}$ & $<\mathrm{MDL}$ & $<\mathrm{MDL}$ \\
\hline Fluconazole & 3 & $227.52-573.76$ & 355.89 & 266.40 & 2 & $145.44-151.16$ & 148.22 & 148.22 \\
\hline Phenylbutazone & 1 & $<\mathrm{MQL}-132.72$ & 132.72 & 132.72 & 0 & $<\mathrm{MQL}$ & $<\mathrm{MQL}$ & $<\mathrm{MQL}$ \\
\hline Prednisone & 2 & $<\mathrm{MQL}-50.24$ & 36.76 & 36.76 & 0 & $<\mathrm{MQL}$ & $<\mathrm{MQL}$ & $<\mathrm{MQL}$ \\
\hline
\end{tabular}

$M Q L$ (method quantification limits $<8 \mathrm{ng} / \mathrm{L}$ ); FO (frequencies of occurrence); C (Concentration),

MDL (method detectation limit) for Betamethasone, Fluconazole, Phenylbutazone was $2.4 \mathrm{ng} / \mathrm{L}$ and for Prednisone was $7.2 \mathrm{ng} / \mathrm{L}$. 
Among the 16 pharmaceutical compounds analyzed in this study, only four of them were detected in the Doce river raw water and one in the water from the Central WTP of Governador Valadares. The pharmaceutical compounds occurrence in natural aqueous matrices is related to seasonal issues as well as socio economic issues and the profile of the population that lives in the region, since these factors influence the type of medicine is most used in the area. In addition, the sampling points may also influence. It is noteworthy that in this study the collections were carried out on the surface of the river Doce in only one point. Thus, it cannot be affirmed that the stretch of the river Doce, that was represented by the samples collected during one year, does not present contamination by other pharmaceutical products that were not contemplated in this study.

Analyzing Table 6, it can be seen that the conventional treatment contemplated in the Central WTP of Governador Valadares obtained a high efficiency in the removal of Betamethasone, Phenylbutazone, and Prednisone, since these drugs were detected in raw water, but were not found in their respective after treatment. This efficiency in the pharmaceutical compounds removal is explained by Huerta-Fontela et al. (2011), which affirm that coagulation using aluminum sulphate $\left(\mathrm{A}_{12}\left(\mathrm{SO}_{4}\right)_{3}\right)$ followed by flocculation may be responsible for the removal of about $30 \%$ of some pharmaceutical compounds. According to Stackelberg et al. 2007 during the coagulation step, the hydrolysis process may occur, contributing to the decrease of pharmaceutical compounds concentration. Moreover, the last stage of the conventional treatment that is thedisinfection of water by chlorine can remove some pharmaceutical compounds by up to $99 \%$ (GIBS et al., 2007; GOGOI et al., 2018).

However, the conventional water treatment system of the Central WTP did not present high efficiency for Fluconazole removal in the $3^{\text {th }}$ sample (November 2016) and in $4^{\text {th }}$ sample (April 2017), presenting removal efficiency of $73 \%$ and $54 \%$, respectively.

\subsection{Conclusions}

Among the 16 pharmaceutical compounds evaluated in this study, only four were detected, the most frequent being Betamethasone. From the fact that only four pharmaceutical compounds were detected in the surface water cannot be affirmed that this water presents only these compounds, since it may occur others that were not contemplated in this study. In addition, the pharmaceutical compounds occurrence in surface water is related to the type of 
collection, which in this study was performed considering only one point on the river surface, and some compounds may be in lower layers or even in the sediment of the river.

The water complete cycle treatment of the WTP Central of Governador Valadares was efficient in the removal of the evaluated pharmaceutical products, only for Fluconazole the station presented this efficiency a little lower than that achieved by membrane. Despite this, it cannot be affirm that this station presents aremoval eficience for the majority of pharmaceuticals compounds that can be found in the natural aquous matrices, since only fourdrugs have been evaluated in this study.

Studies carried out by Loraine and Pettigrove (2006), Stackelberg et al (2004) (2007), Ternes et al (2002) show low efficiency for some pharmaceutical compounds removal during the processes of water clarification and sand filtration. As the Central WTP of Governador Valadares was probably using higher volume and concentration of chemical agents to ensure water quality due to the accident, the pharmaceutical compounds removal was larger than expected for full-cycle water treatment.

\subsection{References}

AGÊNCIA NACIONAL DAS ÁGUAS - Encarte Especial sobre a Bacia do Rio Doce, Rompimento da Barragem em Mariana, MG- 2015.Available in $<$ http://arquivos.ana.gov.br/RioDoce/EncarteRioDoce_22_03_2016v2.pdf $>$.Accessed in October 2017.

BRODIN, T; PIOVANO, S; FICK, J; KLAMINDER, J; HEYNEN, M; JONSSON M. Ecological effects of pharmaceuticals in aquatic systemsdimpacts through behavioural alterations, Philosophical Trans. R. Soc. Lond. B Biol. Sci, v.369, 2014.

EBELE, A. J; ABDALLAH, M,A.E; HARRAD, S. Pharmaceuticals and personal care products (PPCPs) in the freshwater aquatic environment.Emerging Contaminants, p. 1-16, 2016.

GIBS, J; STACKELBERG, P.E; FURLONG, E.T; MEYER, M; ZAUGG, S.D; LIPPINCOTT, R.L. Persistence of pharmaceuticals and other organic compounds in chlorinated drinking water as a function of time. Sci Tot Environ, v.373, p. 240-249,2007.

GOGOI, A; MAZUMDE,P; TYAGI, V.K; CHAMINDA, T; KYOUNGJIN, A; KUMAR. Occurrence and Fate of Emerging Contaminants in Water Environment: A Review, Groundwater for Sustainable Development, 2018.

Programa de Pós-graduação em Saneamento, Meio Ambiente e Recursos Hídricos da UFMG 
HUERTA-FONTELA, M., GALCERAN, M. T., \& VENTURA, F. Occurrence and removal of pharmaceuticals and hormones through drinking water treatment. Water research,v.45, p.1432-1442, 2011.

JELIC, A; GROS, M; GINEBREDA, A; CESPEDES-SÁNCHEZ, R; VENTURA, F; PETROVIC, M; BARCELO, D. Occurrence, partition and removal of pharmaceuticals in sewage water and sludge during wastewater treatment. Water Research, v. 45, p.1165-1176, 2011.

KUMMERER, K. Pharmaceuticals in the Environment, Annu Rev Environ Resour, v. 35, p. 57-75, 2010.

LIMA.D. R. S;ROBSON, J. C. F. A; LIBÂNIO.M; AQUINOA S.F. Avaliação da remoção de fármacos e de desreguladores endócrinos em águas de abastecimento por clarificação em escala de bancada. Quim.Nova, v. 37, p. 783-788, 2014.

LORAINE, G., PETTIGROVE, M. Seasonal variations in concentrations of pharmaceuticals and personal care products in drinking water and reclaimed wastewater in southern California. Environ. Sci. Technol, v. 40,p. 687-695. 2006

NIKOLAOU, A; MERIC S; FATTA, D. Occurrence patterns of pharmaceuticals in water and wastewater environments, Anal. Bioanal. Chem, v. 387, p. 1225e1234, 2007.

PUBCHEM 2017. Available at < https://pubchem.ncbi.nlm.nih.gov/compound/atenolol> Accessed in November 2017.

SAAEGOVAL. Controle de Água - Cartilhas - 2015. Available in $<$ http://www.saaegv.com.br/abrir_arquivo.aspx/Cartilha_2016? cdLocal $=2 \&$ arquivo $=\{$ 7D4C E7B5-EAB5-4D5E-4EBE-07AADAACD2C8\}.pdf >Accessed in October 2016.

SNIS 2014 Ranking do Saneamento. Available in $<$ http://www.tratabrasil.org.br/datafiles/estudos/ranking/2016/tabela-das-100-cidades.pdf $>$ Accessed in October 2016.

STACKELBERG, P.E; FURLONG, E.T; MEYER, M.T; ZAUGG, S.D; HENDERSOND, A.K; REISSMAND, D.B. Persistence of pharmaceutical compounds and other organic wastewater contaminants in a conventional drinking-water-treatment plant. Sci. Total Environ, v.329, p. 99-113, 2004

STACKELBERG, P.E; GIBS, J; FURLONG, E.T; MEYER, M.T; ZUG, S.D; LIPPINCOTT, L. Efficiency of conventional drinking-watertreatment processes in removal of pharmaceuticals and other organic compounds. Sci. Total Environ, v. 377, p. 255-272, 2007.

TERNES, T.A; MEISENHEIMER, M; MCDOWELL, D; SACHER, H; BRAUCH, J;GULDE, B.H; PREUSS, G; WILME, U; SEIRBET, N.Z. Removal of pharmaceuticals during drinking water treatment. Environ. Sci. Technol, v.36, p. 3855-3863, 2002.

Programa de Pós-graduação em Saneamento, Meio Ambiente e Recursos Hídricos da UFMG 


\section{EVALUATION OF NANOFILTRATION AND REVERSE OSMOSIS MEMBRANES TO DRUGS REMOVAL IN THE DOCE RIVER RAW WATER}

\subsection{Introduction}

In recent years there has been increasing concern about the occurrence and adverse effects of emerging pollutants. These pollutants are defined in accordance with the Environmental Protection Agency (EPA) as new chemicals that have no current regulations on their maximum concentration disposal in the natural environment. In addition, the negative impacts caused by these substances on nature and human health are still poorly understood (DEBLONDE et al., 2011; GARCIA-IVARS et al., 2017). This category of pollutants comprises a wide range of substances with different applications and chemical structures. Among these substances, highlights the class of the emerging micropollutants, which are found in the environment at low concentrations, as is the case of pharmaceuticals that are detected in order of nanogram to microgram per liter in aqueous matrices (SANGION GRAMATICA, 2016).

The pharmaceutical compounds occurrence in the water has been widely discussed in the last decade. Many studies have reported the presence of pharmaceuticals in effluents from wastewater treatment plants (RAHMAN, YANFUL \& JASIM, 2009), and these have been identified as a major source of pharmaceuticals in water supply sources, such as rivers, lakes, reservoirs and groundwater aquifers at trace levels (in the range of ng/L to $\mu \mathrm{g} / \mathrm{L}$ ) (ZHANG; GEISSEN \& GAL，2008; HUERTA-FONTELA; GALCERAN \& VENTURA, 2011). Furthermore, the concentrations of some compounds have been found to increase during the treatment process due to the transformation of conjugates back to the parent compounds (WATTS et al., 2007). The presence of trace concentrations of pharmaceutical compounds in the water cycle has increased the concern about the efficacy of water and wastewater treatment processes in removing pharmaceutical compounds.

Membrane technologies demonstrated to be effective barriers to emerging micropollutants from water. Nanofiltration (NF) and reverse osmosis (RO) are membrane technologies that proved to be efficient in the emerging organic contaminants retention from water and wastewater (YOON \& LUEPTOW, 2005; URTIAGA et al., 2013; MARYAM; USTUN \& 
BUYUKGUNGOR, 2017). Motivated by that, many studies have been conducted in order to identify the main retention mechanisms which governed the pharmaceutical compounds retention through this membrane processes.

The steric hindrance effects the main mechanism involved in the pharmaceutical compounds rejectionby NF and RO membranes. Electrostatic effect also plays a significant role in the charged pharmaceutical compounds rejection, justifying the high rejection of negatively charged pharmaceutical compounds by loose nanofiltration membranes (KONG et al., 2015). In addition, almost all pharmaceutical compounds can physically and/or chemically interact with the membrane material, leading to their adsorption onto the membrane and potentially impacting their rejection (VERLIEFDE et al., 2009; STEINLE-DARLIN; LITWILLER \& REINHARD, 2017). The mechanisms of adsorption and their respective impacts on rejection have been investigated, with hydrophobic interactions recognized as the most common mechanism of interaction, which arise from the low surface energy (or, equivalently, high hydrophobicity) of the pharmaceutical compounds and/or the membrane (ISRAELACHVILI, 2015). It has been argued that the effect of hydrophobic interaction on rejection is more pronounced for NF membranes than for RO membranes, likely due to the lower importance of steric hindrance effects for NF membranes (NGHIEM \& SCHÄFER, 2002). However, the inevitable fouling layer on membrane surface can modify the physico-chemical characteristics of the active membrane layer such as pore radius, surface charge and hydrophobicity and influence the membrane rejection mechanisms (LIN; CHIOU \& LEE, 2014). Moreover, the presence of fouling layer could lead to the adsorption of trace contaminants onto the foulants (LI \& LEE, 2014).

Pharmaceutical compounds can also have some specific interactions with the membranes through hydrogen bonding. Both polyamide and cellulose active layers of NF and RO membranes contain functional groups capable of acting as proton donors or acceptors (SCHÄFE; AKANYETI \& SEMIÃO, 2011). Similar to hydrophobic interaction, specific interactions have a more substantial effect on rejection by NF membranes than by RO membranes.

Some studies as COMERTON et al., 2009; RADJENOVIC et al., 2008; HEBERER et al., 2002 and COMERTON et al., 2008, have been conducted to compare the performance of RO

Programa de Pós-graduação em Saneamento, Meio Ambiente e Recursos Hídricos da UFMG 
and NF membranes in rejecting many different pharmaceutical compounds. Generally, RO membranes performed much better than loose NF membranes, especially in the rejection of non-charged and low molecular weight (MW) pharmaceutical compounds (DOEDERER et al., 2014). Nevertheless, tight NF membranes could perform similarly to RO membranes in rejecting most pharmaceutical compounds, with the exception of a few contaminants with specific properties (COMERTON et al., 2008). Furthermore, the NF is can show advantages in terms of energy consumption and water quality. NF membranes are designed to operate at pressures lower than RO membranes resulting in a lower of energy consumption. Besides that, NF to allow the necessary passage of salts that water needs to contain in many applications avoiding the demand of water post-treatment. Notwithstanding, the market favours the popularity and the use of RO membranes.

Although a number of studies have been compared pharmaceutical compounds rejection by NF and RO membrane, many of them were focused on its application in synthetic model waters in wich the target compounds were spiked, making it difficult to obtain conclusive results. In this study performances of surface water treatment by bench-scale NF and RO in terms of rejecting pharmaceutical compounds, water permeability and desalination ability were investigated and compared. The water was collected in the Doce river in the Governador Valadares region where the seweage is discharged without previous treatment. In a previous chapter of this study the pharmaceutical compounds occorrence in this water were evaluated and four pharmaceutical compounds were detected: Betamethasone, Fluconazole, Phenylbutazone, and Prednisone (ng/L). Table 7 summarizes the structures and some physicochemical properties of these pharmaceuticals compounds.

Programa de Pós-graduação em Saneamento, Meio Ambiente e Recursos Hídricos da UFMG 
TABLE 7: The structures and physico-chemical properties of the pharmaceuticals compounds that were found in the Doce river raw water

\begin{tabular}{|c|c|c|c|c|}
\hline Pharmaceutical compounds & Betamethasone & Fluconazole & Phenylbutazone & Prednisone \\
\hline ***Therapeutic class & Corticosteroid & Antifungal & Analgesics & Gluco corticoid receptor \\
\hline$* * *$ Chemical group & $\begin{array}{l}\text { Analgesicsandanti- } \\
\text { inflammatories }\end{array}$ & Antifungal & $\begin{array}{l}\text { Analgesicsandanti- } \\
\text { inflammatories }\end{array}$ & Immunosuppressive \\
\hline *Molecular formula & $\mathrm{C}_{22} \mathrm{H}_{29} \mathrm{FO}_{5}$ & $\mathrm{C}_{13} \mathrm{H}_{12} \mathrm{~F}_{2} \mathrm{~N}_{6} \mathrm{O}$ & $\mathrm{C}_{19} \mathrm{H}_{20} \mathrm{~N}_{2} \mathrm{O}_{2}$ & $\mathrm{C}_{21} \mathrm{H}_{26} \mathrm{O}_{5}$ \\
\hline \multicolumn{5}{|l|}{ **Strutural formula } \\
\hline *Molecular weight $(\mathrm{g} / \mathrm{mol})$ & 393.20 & 306.10 & 309.16 & 358.17 \\
\hline$*$ Log Kow & 1.94 & 0.25 & 3.16 & 1.46 \\
\hline *Dissociation constant & $\mathrm{pKa}=12.42$ & $\mathrm{pKa}=12.71$ & $\mathrm{pKa}=4.50$ & $\mathrm{pKa}=12.58$ \\
\hline$* * *$ Charge at $\mathrm{pH} 7$ & Neutral & Neutral & Negative & Positive \\
\hline *Molar volume $\left(\mathrm{cm}^{3} / \mathrm{mol}\right)$ & 296 & 205 & 263 & 274 \\
\hline *Polarizability $\AA$ & 39.70 & 26.92 & 35.20 & 37.30 \\
\hline *Molecular radius $\AA$ & 6.16 & 5.49 & 6.10 & 6.08 \\
\hline
\end{tabular}

References: * CHEMICALIZE, $2018 * *$ CHEMICALBOOK, 2018 and ***DRUGBANK, 2018.

Programa de Pós-graduação em Saneamento, Meio Ambiente e Recursos Hídricos da UFMG 


\subsection{Materials and methods}

\subsubsection{Water source}

River Doce in the geographical coordinate $18^{\circ} 51^{\prime} 50.45$ "S and $41^{\circ} 56^{\prime} 46.86^{\prime \prime} \mathrm{W}$, which represents a source of drinking water for 400.000 inhabitants and, even with a well-established occupation for over 100 years, receives sewage disposal without previous treatment, until now, was selected to serve as a background matrix to evaluate the pharmaceutical compounds rejection. River Doce water was collected at the intake of Central WTP of Governador Valadares, Minas Gerais, Brazil. Four distinct pharmaceutical compounds have been detected in river Doce water: Betamethasone, Fluconazole, Phenylbutazone, and Prednisone (ng/L).

New plastic bottles were used to collect raw water. These bottles were previously cleaned with the acid bath of $10 \% \mathrm{HCl}$, and then rinsed with deionized water. After collection, the samples were protected from sunlight and stored in the cold camera at $5^{\circ} \mathrm{C}$ until extraction and analytical analyzes (normally, these analyzes were carried out within two days after samples arrived). 


\subsubsection{Membranes}

Five NF and two RO membranes were evaluated in this study. The technical specifications of each membrane, which were obtained from the website of their respective suppliers, can be seen in Table 8.

TABLE 8: Technical membranes characteristics evaluated in this study

\begin{tabular}{|c|c|c|c|c|c|c|c|}
\hline Membrane type & Classification & $\begin{array}{l}\text { Poresize } \\
(\mathrm{mm})\end{array}$ & $\begin{array}{l}{ }^{*} \text { Contact } \\
\text { angle }\left({ }^{\circ}\right)\end{array}$ & $\begin{array}{c}\text { *Zeta potential } \\
\text { pH } 9(\mathrm{mV})\end{array}$ & *Roughness (nm) & $\begin{array}{c}\text { Molecular } \\
\text { weight cut-off } \\
\text { (MWCO) }\end{array}$ & Material \\
\hline Dow Filmtec NF90 & $\mathrm{NF}$ & 0.68 & $44.7 \pm 1.9$ & -21.0 & $72.4 \pm 5.8$ & $200-400$ & Polyamide \\
\hline $\begin{array}{l}\text { Dow Filmtec } \\
\text { NF270 }\end{array}$ & $\mathrm{NF}$ & 0.84 & $32.6 \pm 1.3$ & -41.3 & $9.0 \pm 4.2$ & $200-400$ & Polyamide \\
\hline $\begin{array}{c}\text { Koch Membrane } \\
\text { MPF } 34\end{array}$ & NF & 0.82 & $26.9 \pm 0.4$ & $+12^{3}$ & -2 & 200 & Composite \\
\hline GE Osmonics DK & $\mathrm{NF}$ & 0.76 & $40.6 \pm 5.2$ & -18.5 & $16.4 \pm 3.1$ & $150-300$ & Polyamide \\
\hline $\begin{array}{c}\text { GE Osmonics } \\
\text { Duracid }\end{array}$ & NF & 0.47 & -2 & -2 & -2 & $150-300$ & Polyamide \\
\hline $\begin{array}{c}\text { Dow Filmtec } \\
\text { BW30 }\end{array}$ & $\mathrm{RO}$ & -1 & $25.9 \pm 4.7$ & -10.1 & $68.3 \pm 12.5$ & 100 & Polyamide \\
\hline GE Osmonics SG & $\mathrm{RO}$ & -1 & $72.9 \pm 3.9$ & -24.6 & $17.3 \pm 3.0$ & 100 & Polyamide \\
\hline
\end{tabular}

${ }^{1}$ Pore-free membrane

${ }^{2}$ Data notavailable

${ }^{3}$ YOON \& LEE.,1998; LEE \& LEE., 2007.

*TANG et al.,2009.

Programa de Pós-graduação em Saneamento, Meio Ambiente e Recursos Hídricos da UFMG 


\subsubsection{Experimental set-up and methods}

$\mathrm{NF}$ and RO membranes performance were evaluated in a bench-scale membrane filtration setup (Figure 2). Feed water contained in a temperature-controlled $\left(25 \pm 2{ }^{\circ} \mathrm{C}\right)$ storage tank. Water was transferred to the membrane cells using rotary vane pump, with a variable speed motor and a motor velocity controller (Motron CVE $8701 \mathrm{~F}$ ). The temperature in the temperature-controlled storage tank was controlled using a Chiller (Gelaqua ${ }^{\circledR} 1 / 3$ HP). The feed flowrate and transmembrane pressure were controlled by varying the rotary vane pump speed and controlling a needle valve in the main concentrate stream. The transmembrane pressure was monitored through two manometers located on the in let and outlet of the membrane module. The feed flowrate was measured by a flow meter placed at the retentate outlet. The stainless steel membrane module had a diameter $(2 R)$ of $9 \mathrm{~cm}$, providing a filtration area of $63.60 \mathrm{~cm}^{2}$. The radial inlet radius of the cell $\left(r_{1}\right)$ was $64 \mathrm{~mm}$ and the internal channel height $(2 h)$ was $1 \mathrm{~mm}$. The membranes tested were properly cut before being placed in the cell and a feed spacer with $711 \mu \mathrm{m}$ ( $28 \mathrm{mil})$ was placed over the membrane to promote flow distribution. The scheme of the bench unit used for the NF and RO tests can be seen in Figure 2.

FIGURE 2: Scheme of the NF/RO bench scale unit

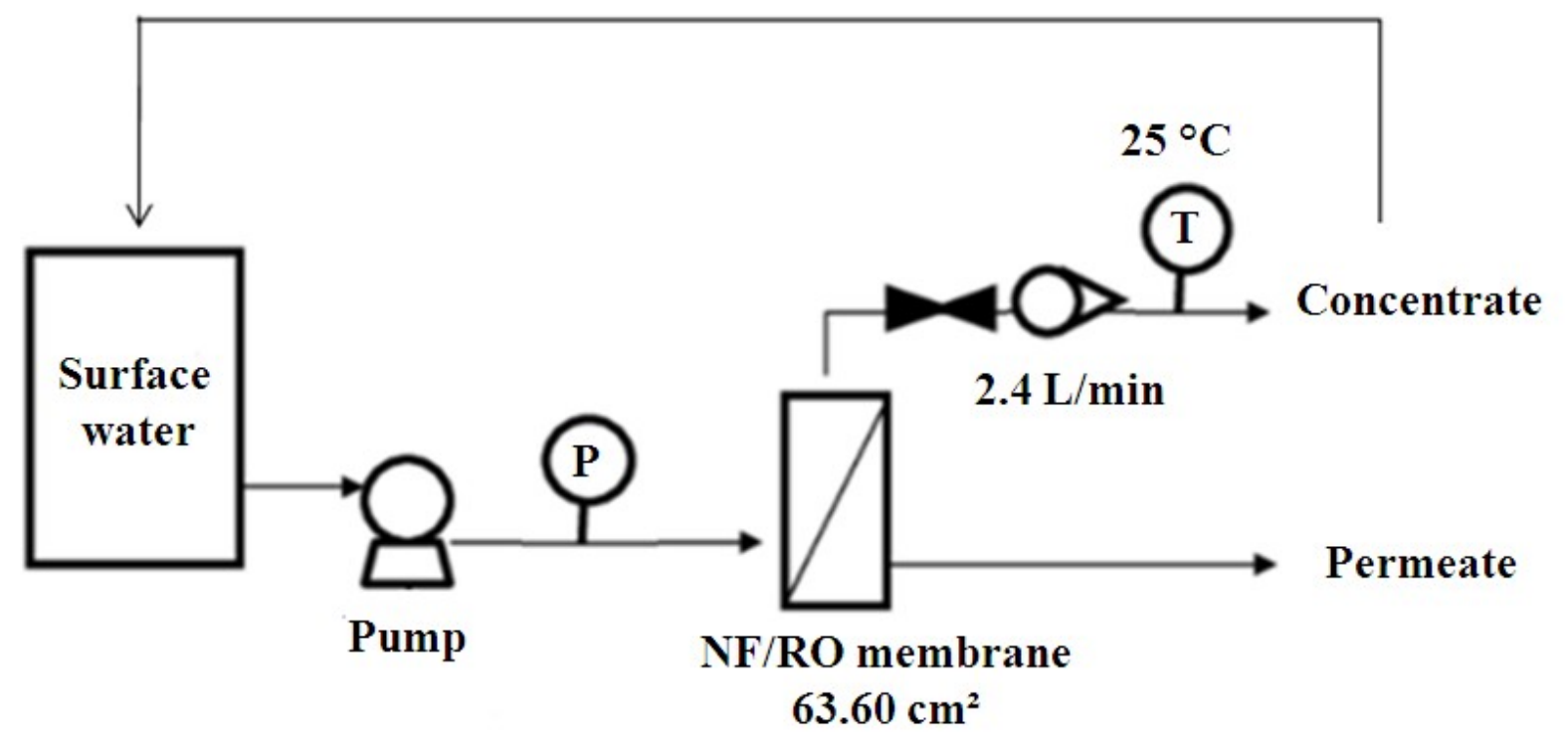

\subsubsection{Experimental procedure}

The seven membranes evaluated in this study were submitted to the same experimental procedure described below. Firstly, the membrane was chemically cleaned using a solution of 
$0.4 \%$ sodium hydroxide and $2 \%$ citric acid for 20 minutes in each solution, respectively, in the ultrasonic bath $\left(\right.$ Sanders $\left.{ }^{\circledR}\right)$. Membrane was rinsed with deionized water after cleaning, started the first step of the test, to obtain a membrane water permeability, the membrane was placed in the steel cell of the MSP unit and its compaction was started for two hours at a pressure of 10 bar until the permeate flow stabilized using $5 \mathrm{~L}$ of deionized water as the feed applying cross flow rate of $2.4 \mathrm{~L} / \mathrm{min}$. With the stabilization of the permeate flow, the operating pressure was varied by $10,8,6$ and 4 bar, maintaining the feed cross flow rate in 2.4 $\mathrm{L} / \mathrm{min}$. Permeate fow of each pressure was measured to guarantee its stabilization in these different conditions, still using the deionized water.

After this, the second step of test was conducted, in wichthe feed of deionized water was replaced by $5 \mathrm{~L}$ of Doce river raw water, and the permeationwas started maintaining the pressure of 10 bar and the same feed cross flow rate. During this operation, the permeate flux was monitored every 5 minutes during the first 30 minutes of the test and the concentrate was returned to the feed tank. After this, the monitoring was performed every 10 minutes up to the $30 \%$ recovery rate.

The third procedure that was adopted was the membrane physical cleaning provoking the circulation of deionized water without pressure and applying the feed cross flow rate of 1.2 $\mathrm{L} / \mathrm{min}$ to remove all or only a fraction of the organic products that deposited on the surface of the membrane during the permeation of Doce river raw water.

In sequence, the membrane was removed from the steel cell and submitted to chemical cleaning using $2 \%$ citric acid in an ultrasonic bath for 20 minutes. Finally, the last stage of the test was performed, in withthe membrane was returned to the cell of the filtration unit and the permeate flow was measured until stabilized by varying the pressures at 10, 8, 6 and 4 bar using deionized water in the same initial conditions.

\subsubsection{Calculations}

The permeate flux $(\mathrm{J})$ was measured in liters per square meter per hour $\left(\mathrm{L} / \mathrm{m}^{2} . \mathrm{h}\right)$ applying the Eq. (1).

$I(T)=\frac{\Delta V}{A m \times \Delta t}$ 
Where $\mathrm{J}(\mathrm{T})$ is the permeate flux at a temperature $\mathrm{T}, \Delta \mathrm{V}$ is the total volume of the permeate (L) collected in the $\Delta t$, the filtration time ( $\mathrm{min}$ ), and Am is the effective membrane filtration area $\left(\mathrm{m}^{2}\right)$.

Flux data were normalized at $25{ }^{\circ} \mathrm{C}$ using a correction factor calculated from the ratio of water viscosity at the permeation temperature and water viscosity at $25^{\circ} \mathrm{C}$ as shown in Eq. 2 .

$J\left(25^{\circ} \mathrm{C}\right)=J(T) \cdot \frac{\mu(T)}{\mu\left(25^{\circ} \mathrm{C}\right)}$

Where $\mathrm{J}(\mathrm{T})$ is the permeate flow at the permeation temperature, obtained in Equation $1, \mu(T)$ is the dynamic viscosity of the water at the permeation temperature, $\mu\left(25^{\circ} \mathrm{C}\right)$ is the dynamic viscosity of the water at $25^{\circ} \mathrm{C}$ and $\mathrm{J}\left(25^{\circ} \mathrm{C}\right)$ is the permeate flux corrected to $25^{\circ} \mathrm{C}$.

The observed removal was calculated using Eq. (3), as follows:

$R(\%)=\frac{C_{f}-c_{p}}{C_{f}} \times 100$,

Where $C_{f}$ and $C_{p}$ represent the solute content in the feed and permeate streams, respectively.

According to the simplified resistance-in-series model, the total filtration resistance could be divided into membrane resistance and fouling resistance. The membrane resistance to filtration $\left(\mathrm{R}_{\mathrm{M}}\right)$ was determined from Eq. (4) where $k$ represents membrane permeability:

$R_{M}=\frac{1}{K \cdot \mu\left(25^{\circ} \mathrm{C}\right)}$

The total fouling resistance to filtration $\left(\mathrm{R}_{f}\right)$ was calculated based on the values of the normalized effluent permeate flux $\left(\mathrm{J}_{\mathrm{Sd}}\right)$ obtained near the end of each experiment (Eq. 2). This resistance includes the concentration polarization, adsorption of components on the membrane surface, and scaling.

$R_{f}=\frac{\Delta P}{\mu\left(25^{\circ} \mathrm{C}\right) J_{s d}}-R_{M}$

Where $(\Delta \mathrm{P})$ is the transmembrane pressure.

The fouling resistance $\left(R_{f}\right)$ is a combination of the resistance caused by reversible fouling $\left(R_{f r}\right)$ and the irreversible fouling layer $\left(R_{f i r}\right) . R_{f r}$ is mostly due to the deposition of a cake layer on the membrane surface, which can be removed through physical cleaning, such as water 
washing; thus, it can be controlled by adjusting the feed flow conditions. $R_{f i r}$ is due to materials that adsorb into the membrane surface and into the pores that can be removed by chemical cleaning.

The total permeateflux decline $(F D)$ during the filtration test can be obtained using Eq. (6) which compares the permeate flux of deionized water $\left(\mathrm{J}_{\mathrm{w}}\right)$ obtained in the first step of this procedure, with the virgin membrane clean with the last measurement of the permeate flow using the Doce river raw water $\left(\mathrm{J}_{\mathrm{sd}}\right)$ :

$F D=\frac{(\mathrm{Jw}-\mathrm{Jsd})}{J w}$

This decline in the permeate flux during the tests is due to concentration polarization and fouling, that iscaused with deposition of organic and inorganic matter on the surface of the membrane. Thus, it is possible to calculate the decline of the permeate flux attributed to the concentration polarization $(C P)$ using Eq. (7), where $\mathrm{J}_{\mathrm{pc}}$ is the volumetric water flux of the physically cleaned membrane after effluent filtration.

$C P=\frac{\left(J_{p c}-J_{s d}\right)}{J w}$

The specific energy consumption SEC ( $\mathrm{kWh} / \mathrm{m}^{3}$ of permeate) was calculated according to Eq 8 and 9.

$\mathrm{SEC}=\frac{\mathbf{w}}{\mathbf{Q}_{\mathbf{P}}}$

$\mathrm{W}=\frac{\Delta \mathbf{P} \times \mathbf{Q}_{\mathrm{F}}}{3.6 \times 10^{6}}$

Where $\mathrm{W}$ is the rate of work done by the pump $(\mathrm{kWh} / \mathrm{s}), \Delta P$ is the difference between the feed pressure at the entrance of the membrane and the pressure of the raw water, which is assumed to be equal to the atmospheric pressure $\left(\mathrm{N} / \mathrm{m}^{2}\right)$, and $Q_{F}$ and $Q_{P}$ are the feed and permeate flow rates $\left(\mathrm{m}^{3} / \mathrm{s}\right)$, respectively.

\subsubsection{Analytical methods}

The collected samples of water and permeates were analyzed according tothe following parameters: Turbidity (Hach 2100AN Turbidimeter) (Method 2130B), pH (Qualxtron QX $1500 \mathrm{pH}$ meter) (Method 4500B), absorption at $254 \mathrm{~nm}$ and apparent color (Hach 
Spectrophotometer DR 2800) (Method 2120B), total suspended solids (TSS) (Method 2540B), total organic carbon (Shimadzu TOC-V CNP TOC Analyzer) (Method 5310), conductivity (Hanna HI 9835 Conductivity Meter) (Method 2510 B) and ion scan (ICP-OS) (Method 4110B). These analyses were made according tothe recommendations of Standard Methods for the Examination of Water and Wastewater (APHA 2012). All these analyzes were carried out in triplicates in the laboratories of the Departamento de Engenharia Sanitária e Ambiental (DESA) of Universidade Federal de Minas Gerais (UFMG).

Pharmaceutical compounds were analyzed using a HPLC (DGU/20A3 Prominence, Shimadzu, Japan) coupled to the micrOTOF-QII mass spectrometer (Bruker) with an electrospray ionization source (ESI) in positive mode. The detection limit for each pharmaceutical compound was around $8 \mathrm{ng} / \mathrm{L}$. The uncertainty of estimates is of $1 \%$ according to a validation method of the analysis protocol. Recoveries are between 86 and $100 \%$ but are compensated by the calibration, which is processed the same way as the samples. Water samples were previously filtered in $0.45 \mu \mathrm{m}$ hydrophilic PVDF filter. Analytes were isolated from water samples (1 L) in two steps, firstly without pH adjustment ( $\mathrm{pH} 7$ ) and then with $\mathrm{pH}$ adjustment to 2 by adding $0.002 \mathrm{mols} / \mathrm{L} \mathrm{H}_{2} \mathrm{SO}_{4}$ solution, using a polymeric C18/18\% cartridge (500 mg/6 mL - Applied Separations) preconditioned with 5 $\mathrm{mL}$ of methanol and $5 \mathrm{~mL}$ of ultra pure water, and then eluted with methanol using Aspec Gilson GX-271 Liquid Handler. Separation was achieved on a Shim-pack XR-ODS C18 column $(2.0 \mathrm{~mm} ; 50 \mathrm{~mm}$ and $2.0 \mu \mathrm{m}$; Shimadzu, Japan) with the mixture of $0.1 \%$ of formic acid water and methanol as the mobile phase. The flow rate and injection volume were 0.1 $\mathrm{mL} / \mathrm{min}$ and $10 \mu \mathrm{L}$, respectively. The mobile phase gradient followed an isocratic method using $95 \%$ of methanol for 15 minutes.

\subsection{Results}

\subsubsection{Membrane fouling}

Figure 3 shows reversible and irreversible membranes fouling resistances for the different NF and RO membranes evaluated. 
FIGURE 3: Fouling resistances (reversible and irreversible) in NF and RO membranes treating surface water ( $x 10^{12}$ for NF membranes and $\times 10^{13}$ for RO membranes)

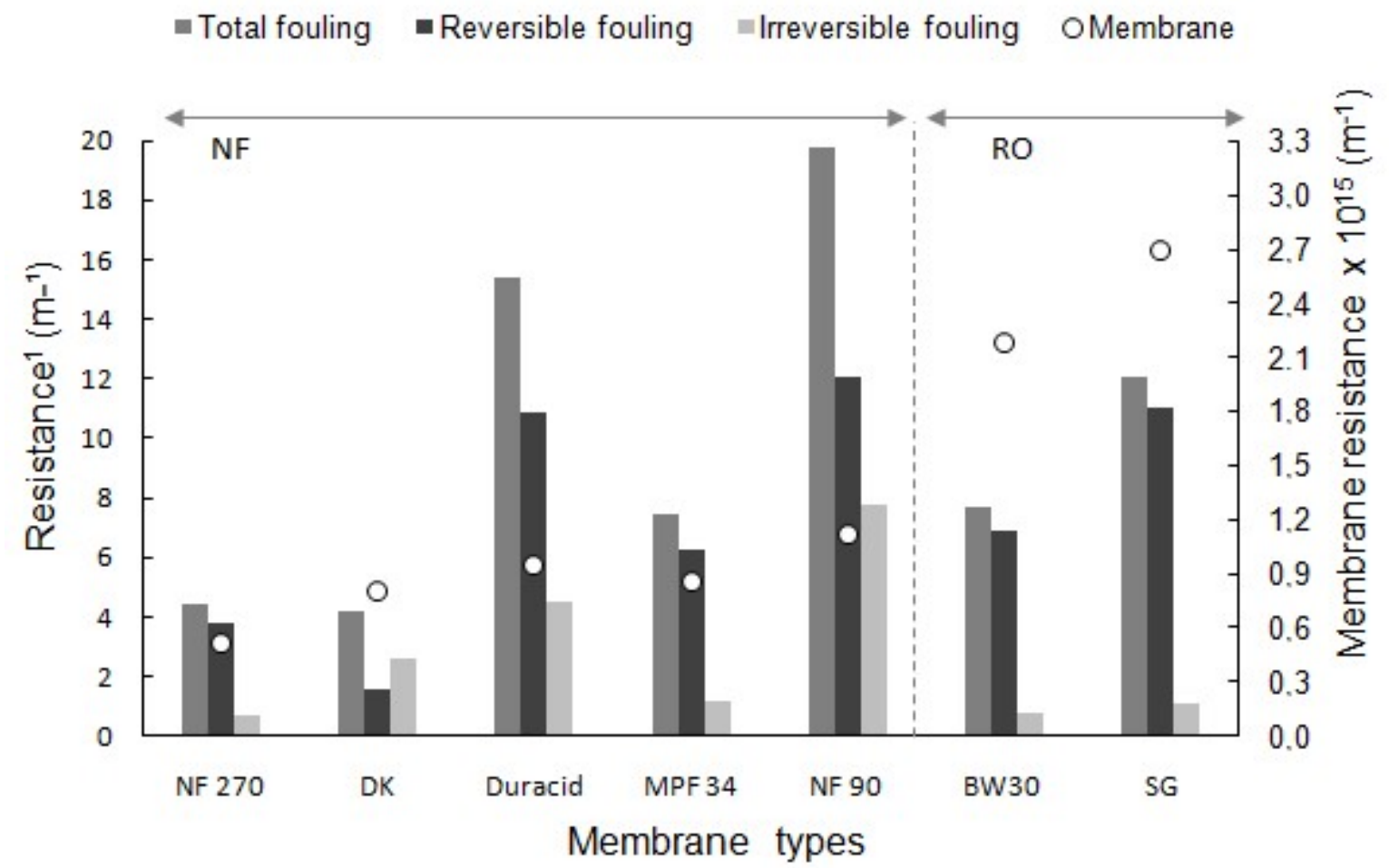

As can be seen in Figure 3, the membrane intrinsic resistance is higher for reverse osmosis, since these membranes are considered dense because they don't have pores, but theyhave some interstices that allow the passage of the solvent (TU, CHIVAS \& NGHIEM, 2011). The NF 270 nanofiltration membrane had the lowest intrinsic membrane resistance because it is the loosest membrane that was evaluated in this study, which facilitates the permeation of water through the selective barrier. Among the nanofiltration membranes that were evaluated, the NF 90 was the tightest membrane presenting the smallest poressize, consequently, NF 90 had the highest intrinsic resistance since the solvent find more obstacles to cross the membrane than other nanofiltration membranes.

The flux decline could be associated with concentration polarization and fouling phenomena. The flux decline observed during the surface water permeation by the nanofiltration and reverse osmosis membranes occurred mainly due to concentration polarization (Table 9). 
TABLE 9: Permeate flux, flux decline along the test and specific energy consumed for each membrane evaluated in this study using 10 bar of pressure and $2.4 \mathrm{~L} / \mathrm{min}$ of feed flow rate

\begin{tabular}{|c|c|c|c|c|c|c|c|c|}
\hline \multirow{2}{*}{ Membrane } & \multirow{2}{*}{$\begin{array}{c}\mathbf{J}_{\mathbf{w}}^{\mathbf{a}} \\
\left(\mathbf{L} / \mathbf{m}^{2} \cdot \mathbf{h}\right)\end{array}$} & \multirow{2}{*}{$\begin{array}{c}\mathbf{J}_{\text {sd }}^{b} \\
\left(\mathrm{~L} / \mathbf{m}^{2} \cdot h\right)\end{array}$} & \multirow{2}{*}{$\begin{array}{c}\mathbf{J}_{\mathbf{p c}} \mathbf{c} \\
\left(\mathbf{L} / \mathbf{m}^{2} . \mathbf{h}\right)\end{array}$} & \multirow{2}{*}{$\begin{array}{c}\mathbf{J}_{\mathrm{cc}}^{\mathbf{d}} \\
\left(\mathrm{L} / \mathbf{m}^{2} \cdot \mathbf{h}\right)\end{array}$} & \multicolumn{3}{|c|}{ Flux decline type (\%) } & \multirow{2}{*}{$\begin{array}{c}\text { SEC } \\
\left(k W h . m^{3}\right)\end{array}$} \\
\hline & & & & & Total & Fouling & $\mathbf{C} \mathbf{P}^{\mathbf{e}}$ & \\
\hline NF 270 & 77.70 & 72.00 & 77.2 & 77.50 & 8 & 1 & 7 & 0.21 \\
\hline DK & 50.00 & 47.71 & 48.63 & 49.10 & 5 & 3 & 2 & 0.32 \\
\hline Duracid & 42.40 & 36.53 & 40.54 & 41.37 & 14 & 5 & 9 & 0.42 \\
\hline MPF 34 & 47.16 & 43.16 & 46.26 & 46.39 & 8 & 2 & 6 & 0.35 \\
\hline NF 90 & 35.98 & 30.52 & 33.58 & 35.73 & 15 & 7 & 8 & 0.50 \\
\hline BW30 & 18.47 & 13.65 & 17.79 & 17.93 & 26 & 4 & 22 & 1.12 \\
\hline SG & 15.04 & 10.32 & 14.37 & 15.00 & 31 & 4 & 27 & 1.49 \\
\hline
\end{tabular}

initial effluent permeate flux;

${ }^{\mathrm{b}}$ final effluent permeate flux;

${ }^{c}$ water permeate flux after physical cleaning

dwater permeate flux after chemical cleaning;

epermeate flux decline attributed to the concentration polarization

It is noteworthy that there is no correlation between membrane fouling and pore diameter suggesting that other membrane properties play a more important role in the mechanism of membrane fouling. Among the nanofiltration membranes, the lower membrane fouling observed with the DK and NF270 membrane could be attributed to the greater pore diameter associated to low surface roughness, low hydrophobicity and high negative zeta potential (Table 8) which could subsequently lead to lower fouling potential compared with others membranes. The high surface roughness of a membrane could render this membrane more susceptible to fouling because foulant particles could accumulate in the valleys on the membrane surface due to higher local flux over valley regions (TU, CHIVAS \& NGHIEM, 2011). According to Schäfer, Faneand Waite (2000) a more negative membrane zeta potential could lead to a higher salt rejection due to an enhanced electrostatic interaction between the negatively charged membrane surface and charged solutes. The relative smaller membrane fouling observed with the DK membrane compared with NF 270 membrane could be associated to the higher operational permeate flux $\left(72 \mathrm{~L} \mathrm{~m}^{-2} \mathrm{~h}^{-1}\right)$ in comparison to that (48 $\mathrm{L}$ $\mathrm{m}^{-2} \mathrm{~h}^{-1}$ ) of the DK membrane (Table 9). The higher permeate flux introduced more foulant to the membrane surface, and subsequently encouraged fouling on the NF 270 membrane.

Altough SG reverse osmosis membrane has a smooth surface and higher negative zeta compared to that of the BW 30 membrane, the SG membrane showed the higher fouling resistance. The greater fouling potencial of the SG membrane could be related to the higher hydrophobicity that could make the SG membrane more vulnerable to fouling due to 
hydrophobic interaction between membrane surface and hydrophobic foulants present in the surface water.

RO membranes weremore severely influenced fouling than the NF membranes due to higher rejection efficiency of the RO membranes compared to the NF membranes that showed a greater concentration polarisation at the membrane surface (Table 9). The contribution of concentration polarisation to total flux decline in the RO membrane range from 22 to $27 \%$ whereasfor NF membrane the concetration polarisation contributes to 2-9\%. Consequently, membrane fouling was more severe for the RO than for the NF membrane. It can also be observed that greater fraction of fouling in both NF and RO are reversible and only a small fraction requires chemical cleaning to be removed. The high intrinsic membrane resistance and fouling resistance for RO membrane imply in the higher specific energy consumption for

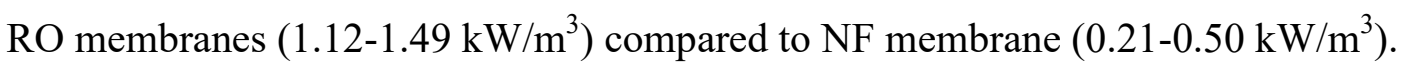

\subsubsection{Desalination ability}

It is necessary to know the physico-chemical characteristics of the feed, since the elements present in this solution interfere in the interaction of the feed with the membrane surface, therefore also influences the permeate flux and the mass transfer during the permeation process. In addition, when comparing the physico-chemical characterization of the feed with the results of the same analyzes from permeates producted during the tests of each membrane, it is possible to verify the efficiency of each membrane that was evaluated.

These results of the first sample (April 2016) of surface water, and of permeates producted by each membrane evaluated in this study can be seen in Table 10. 
TABLE 10: Physico-chemical analysis results of the surface water collected in April 2016, and of the permeates producted by NF and RO membranes using 10 bar of pressure and $2.4 \mathrm{~L} / \mathrm{min}$ of feed flow rate

\begin{tabular}{|c|c|c|c|c|c|c|c|c|c|}
\hline & $\begin{array}{c}\text { Surface } \\
\text { water }\end{array}$ & NF 270 & DK & MPF 34 & DURACID & NF 90 & BW30 & SG & $\begin{array}{c}\text { Potability } \\
\text { standards } \\
\text { No }^{\circ} \mathbf{2 9 1 4 / 2 0 1 1} \\
\end{array}$ \\
\hline Parameter & Value & Value & Value & Value & Value & Value & Value & Value & Value \\
\hline $\mathrm{pH}$ & 7.10 & 6.57 & 6.37 & 6.41 & 6.33 & 6.35 & 6.41 & 6.70 & $6.00-9.00$ \\
\hline $\begin{array}{l}\text { Conductivity } \\
(\mu \mathrm{S} / \mathrm{cm})\end{array}$ & 161.00 & 33.60 & 17.89 & 35.60 & 14.70 & 21.40 & 34.40 & 36.30 & -1 \\
\hline $\begin{array}{l}\text { Turbidity } \\
\text { (NTU) }\end{array}$ & 56.50 & 0.08 & 0.08 & 0.07 & 0.08 & 0.06 & 0.07 & 0.07 & 0.50 \\
\hline $\mathrm{TSS}(\mathrm{mg} / \mathrm{L})$ & 20.000 & $<0.001$ & $<0.001$ & $<0.001$ & $<0.001$ & $<0.001$ & $<0.001$ & $<0.001$ & -1 \\
\hline $\begin{array}{c}\text { Apparent } \\
\text { color } \\
\text { (mg Pt-Co/L) }\end{array}$ & 196 & $<5$ & $<5$ & $<5$ & $<5$ & $<5$ & $<5$ & $<5$ & 15 \\
\hline $\begin{array}{c}\text { UV } \\
\text { Absorbance } \\
(254 \mathrm{~nm}) \\
\end{array}$ & 0.349 & 0.009 & 0.002 & 0.018 & 0.010 & 0.010 & 0.001 & 0.002 & -1 \\
\hline TOC (mg/L) & 2.53 & 0.91 & 0.86 & 1.00 & 0.47 & 0.53 & 0.50 & 0.39 & -1 \\
\hline $\mathrm{Ca}(\mathrm{mg} / \mathrm{L})$ & 12.38 & $<2.50$ & $<2.50$ & $<2.50$ & $<2.50$ & $<2.50$ & $<2.50$ & $<2.50$ & -1 \\
\hline $\operatorname{Mg}(\mathrm{mg} / \mathrm{L})$ & $<1.25$ & $<1.25$ & $<1.25$ & $<1.25$ & $<1.25$ & $<1.25$ & $<1.25$ & $<1.25$ & -1 \\
\hline $\mathrm{Na}(\mathrm{mg} / \mathrm{L})$ & 6.40 & $<1.00$ & $<1.00$ & $<1.00$ & $<1.00$ & $<1.00$ & $<1.00$ & $<1.00$ & 200.00 \\
\hline $\mathrm{K}(\mathrm{mg} / \mathrm{L})$ & 2.70 & $<2.50$ & $<2.50$ & $<2.50$ & $<2.50$ & $<2.50$ & $<2.50$ & $<2.50$ & -1 \\
\hline
\end{tabular}

${ }^{-1}$ Parameter not covered by Brazilian Potable Water Legislation $n^{\circ} 2914$ 
Sodium can be incorporated into natural water by two routes, being natural through the rocky composition of the region and the second source is related to anthropic activities due to contamination of sanitary and industrial sewage (USEPA, 2015; VON SPERLING, 2007; PIRATOBA et al., 2017). Despite the Governador Valadares discharge all sewage, that was producted in the city, directly into the river without any kind of treatment, the sodium concentration that was found in the feed was low. This fact can be explained by the great avarenge flow rate of $11 \mathrm{~L} / \mathrm{s} . \mathrm{km}^{2}$ which allows the dilution of this element (PIRH, 2010). It is observed that when the membrane was filtered, the sodium concentration decreased considerably, being below the limit of detection of the method that was used.

The same happened to potassium, which according to Zuin et al (2009) this chemical element is found in low concentrations in natural environments, being its main natural source the leaching of rocks and anthropogenic activities, stands out the contamination by the industry and in the farming. The low concentration of potassium in the feed source of the tests can also be explained by the dilution by the great volume of water of the Doce river.

The hardness of water is usually associated with the presence of calcium and magnesium. These two elements have as main route of entry in natural water matrices through the leaching of the rocks present in the region. In this case, the hardness of the sample was attributed to the calcium concentration, which was retained by the membranes evaluated; presenting results in permeates of values below the limit of detection of the method.

According to Tundisi and Matsumura (2008), the conductivity in a water body is related to the concentration of ions present in it, which can also be influenced by the rocky composition of the region. Observing results of Table 10, the concentration of this parameter in permeates reduced considerably compared to the raw water. The highest efficiencies obtained were of $89.0 \%$ and $88.9 \%$ for the Duracid and DK membranes, respectively.

All the evaluated membranes removed more than $99 \%$ of the TSS, so they also showed high efficiency in the removal of the apparent color and the turbidity, since the TSS concentration contributed to the increase of the turbidity, since this parameter hinders the penetration of light into water (CARRERAS, 2010).

The TOC analysis was performed in substitution of the chemical oxygen demand (COD) analysis, since the concentration of COD in the raw water and in permeates was below the detection limit of the method. The TOC analysis considers the biodegradable and non- 
biodegradable portions of organic matter. Organic carbon in fresh water originates from living matter and also as a component of several effluents and wastes, thus TOC being an indicator of the degree of pollution of the water body (CETESB, 2016). Analyzing the data referring to this parameter in the Table 10, it is possible to notice that the surface water did not present great presence of organic carbon, in spite of the river receiving the sewage producted in the city of Governador Valadares without previous treatment. This fact can also be explained by the large volume of the river, which leads to the dilution of this carbon. In addition, there is also the auto depuration capacity of the river that can contribute to the low concentrations of carbon in this water course.

But, observing Table 10, the TOC rejection for NF 90 membrane is compatible with RO performance. Although there is no legal TOC limit for drinking water, it is important to note that the composition of the organic fraction is more important than the global TOC concentration/rejection due to the possibility of the presence of micropollutants. NF and RO membrane UV Absorbance (254nm) rejection was also high, above 97 and 99\% for NF and RO, respectively. This higher rejection was reached because these membranes preferentially remove the aromatic/ hydrophobic organics to which UV Absorbance (254 $\mathrm{nm}$ ) is attributed (RUBIA et al., 2008).

\subsubsection{Pharmaceutical compounds rejection}

In the $2^{\text {th }}$ chapter of this study, was mentioneted the occorrence of three phamarceutical compounds that were detected recurrently in the first sample (April 2016) of the Doce river surface water: Fluconazole, Phenylbutazone, and Prednisone. These pharmaceutical compounds are in the group of the most frequently prescribed in human medicine. In Brazil, as well as the European Union, there are no legal limits of these compounds in the drinking water. Table 11 summarizes the structures and physico-chemical properties of presented compounds. 
TABLE 11: Pharmaceutical compounds that were found in the surface water samples collected in April 2016 and their physico-chemical properties

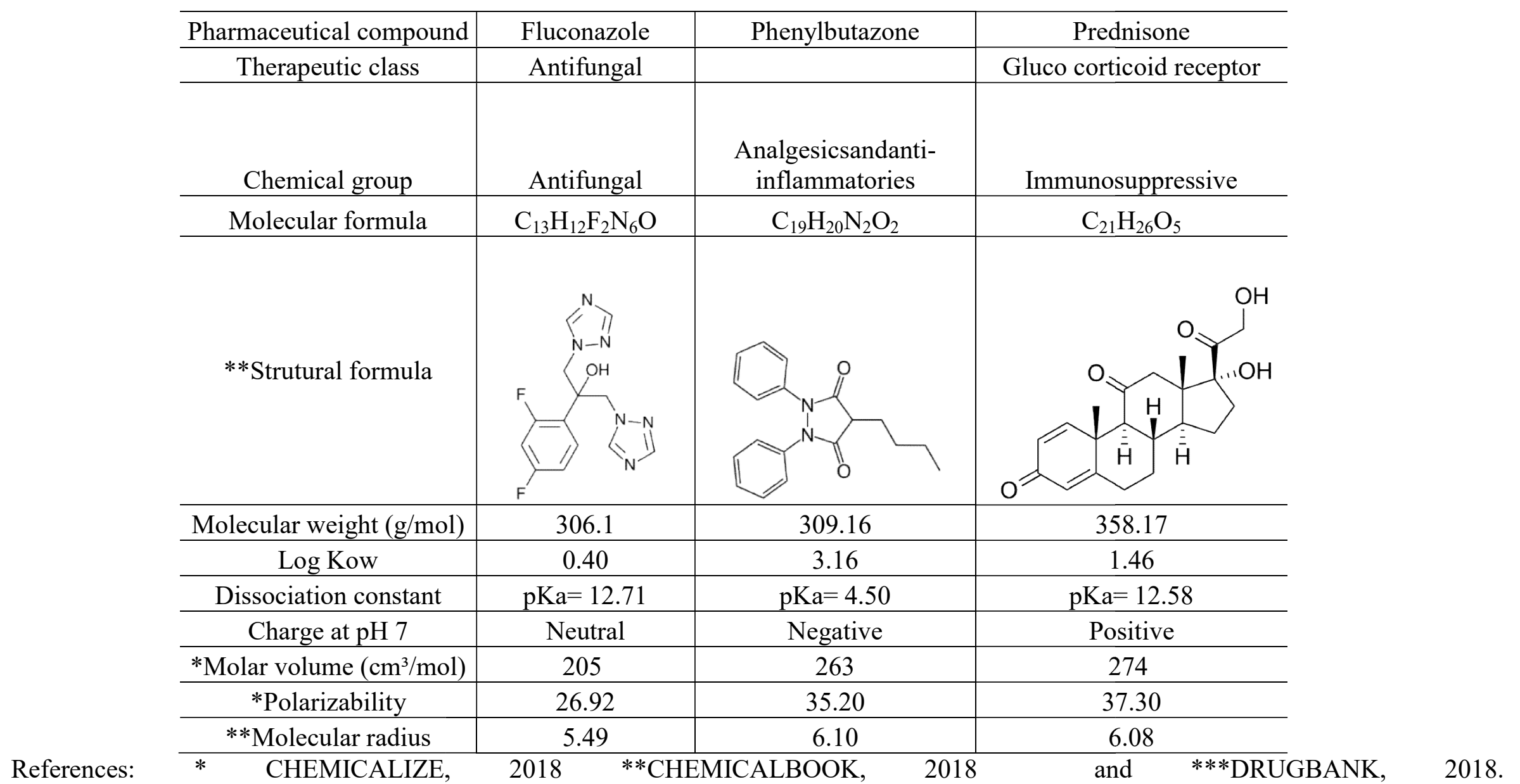


The organic compounds presented in the surface water have similar molecular weight and molecular radius but they have distinguishing properties (hydrophobicity and dissociation constants) that makes them interesting to be compared. Regarding the hydrophilic or hydrophobic character of pharmaceutical compound, the octanol-water partition coefficient (Kow) can be used as an indicator of the sorption properties of a pollutant, which indicates its hydrophobicity. The organic compounds with a value of $\log$ Kow higher than 2 could be considered as hydrophobic, that facilitates its adsorption in the membrane by making hydrogen bonds between these solutes and the surface of the membrane. Usually, when the $\mathrm{pH}$ of the solution is higher than the intrinsic $\mathrm{pKa}$ value of the target compound, this compound is deprotonated and presents a negative charge. Otherwise, the charge of the organic compound may be neutral or positive or a mixture of both (GANIYU et al., 2015). Since the river Doce water has $\mathrm{pH}$ around 7, Fluconazole has a neutral charge, whereas Phenylbutazone and Prednisone have a negative and positive charge. Table 12 shows pharmaceutical compounds concentrations that were found in the surface watersample collected in April 2016 and permeates from NF and RO membranes.

TABLE 12: The pharmaceutical compounds found in the first surface water sample (April 2016) and in the permeates from five NF and two RO membranes evaluated in this study, where MQL is the method quantification limit

\begin{tabular}{cccc}
\hline & $\begin{array}{c}\text { Fluconazole } \\
\mathbf{( n g / L )}\end{array}$ & $\begin{array}{c}\text { Phenylbutazone } \\
\mathbf{( n g} / \mathbf{L})\end{array}$ & $\begin{array}{c}\text { Prednisone } \\
\text { (ng/L) }\end{array}$ \\
Surface water (Feed) & 227.52 & 132.72 & 50.32 \\
NF 270 permeate & $<\mathrm{MQL}$ & $<\mathrm{MQL}$ & $<\mathrm{MQL}$ \\
DK permeate & $<\mathrm{MDL}$ & $<\mathrm{MDL}$ & $<\mathrm{MDL}$ \\
MPF 34 permeate & $<\mathrm{MQL}$ & $<\mathrm{MQL}$ & $<\mathrm{MQL}$ \\
Duracid permeate & 159.60 & $<\mathrm{MQL}$ & $<\mathrm{MQL}$ \\
NF 90 permeate & $<\mathrm{MQL}$ & $<\mathrm{MQL}$ & $<\mathrm{MQL}$ \\
BW 30 permeate & $<\mathrm{MQL}$ & $<\mathrm{MQL}$ & $<\mathrm{MQL}$ \\
SG permeate & $<\mathrm{MQL}$ & $<\mathrm{MQL}$ & $<\mathrm{MQL}$ \\
$M Q L=8 n g / L$ & \multicolumn{3}{|}{}
\end{tabular}

Except for the Duracid membrane, all others membranes showed high pharmaceutical compounds rejection $(>96.5 \%,>94.1 \%$ and $>84.1 \%$ Fluconazole, Phenylbutazone and Prednisone, respectively) reducing the concentration of pharmaceutical compound to value lower than method quatification limit $(8 \mathrm{ng} / \mathrm{L})$ and $\mathrm{DK}$ membrane was the only membrane that reached the best pharmaceuticals compounds removal reaching the MDL of each of them. Considering that the pharmaceutical compound molecular radius is greater than the pore 
radius of all membranes evaluated and that both compounds and membranes have differents proprieties, the high pharmaceutical compound rejection suggests that main mechanism involved in the NF and RO membane is the size exclusion except to Duracid membrane. The low rejection of Fluconazole (30\%), a neutral and hydrophilic compound, by Duracid NF membrane suggests that others mechanism play role in the rejection of this pharmaceutical compound by this membrane. In general, the pharmaceutical compound removal is not solely dependent on the molecular size. According to Bellona, Marts and Drewes (2004) the hydrophobic interaction between the pharmaceutical compound and the membrane is an important factor for rejection. Furthermore, because Fluconazole is neutral under the experimental conditions, electrostatic repulsion did not contribute to its rejection.

\subsubsection{Choice of membrane}

Among the evaluated membranes, the DK NF membrane was selected as being the most suitable for the surface water treatment since it showed high desalination ability and pharmaceutical compound rejection associated with high permeate flux, low fouling potential and specific energy consumption. This membrane was employed for the treatment of five river Doce samples collected quarterly. Evaluation of the pharmaceutical compounds removal present in the Doce river water using the DK nanofiltration membrane achieved the best result set.

\subsubsection{Physico-chemical analysis}

The physical and chemical results of all collects of the surface water, as well as their respective permeates and the removal efficiencies of each parameter achieved by the DK membrane can be observed in Table 13. The DK membrane operated in the conditionals of 10 bar of transmembrane pressure and $3.2 \mathrm{~L} / \mathrm{min}$ of feed flux. 
TABLE 13: Average, standard deviation and median of the physico-chemical results of surface water and permeates, as well as the removal efficiency of each parameter reached by the DK nanofiltration membrane

\begin{tabular}{c|c|c|c|c|c|c|c|c|c|c|c}
\hline Parameter & $\mathrm{pH}$ & $\begin{array}{c}\text { Apparent } \\
\text { color } \\
(\mathrm{mg} / \mathrm{L} \text { Pt } \\
\mathrm{Co})\end{array}$ & $\begin{array}{c}\text { UV } \\
\text { Absorbance } \\
(254 \mathrm{~nm})\end{array}$ & $\begin{array}{c}\text { Turbidity } \\
(\mathrm{NTU})\end{array}$ & $\begin{array}{c}\mathrm{TOC} \\
(\mathrm{mg} / \mathrm{L})\end{array}$ & $\begin{array}{c}\mathrm{TSS} \\
(\mathrm{mg} / \mathrm{L})\end{array}$ & Conductivity & $\begin{array}{c}\mathrm{Ca} \\
(\mathrm{mg} / \mathrm{L})\end{array}$ & $\begin{array}{c}\mathrm{Mg} \\
(\mathrm{mg} / \mathrm{L})\end{array}$ & $\begin{array}{c}\mathrm{Na} \\
(\mathrm{mg} / \mathrm{L})\end{array}$ & $\begin{array}{c}\mathrm{K} \\
(\mathrm{mg} / \mathrm{L})\end{array}$ \\
\hline $\begin{array}{c}\text { Surface } \\
\text { water }\end{array}$ & $\begin{array}{c}7.1 \pm 0.2 \\
(7.1)\end{array}$ & $\begin{array}{c}41.2 \pm 39.1 \\
(28.0)\end{array}$ & $\begin{array}{c}0.7 \pm 0.1 \\
(0.7)\end{array}$ & $\begin{array}{c}22.6 \pm 18.9 \\
(14.0)\end{array}$ & $\begin{array}{c}3.3 \pm 1.8 \\
(2.4)\end{array}$ & $\begin{array}{c}9.6 \pm 7.5 \\
(6.0)\end{array}$ & $\begin{array}{c}129.0 \pm 26.6 \\
(115.0)\end{array}$ & $\begin{array}{c}4.32 \pm 0.9 \\
(4.1)\end{array}$ & $\begin{array}{c}1.9 \pm 0.3 \\
(1.9)\end{array}$ & $\begin{array}{c}3.9 \pm 0.5 \\
(0.5)\end{array}$ & $\begin{array}{c}2.7 \pm 0.2 \\
(2.7)\end{array}$ \\
\hline Permeate & $\begin{array}{c}6.9 \pm 0.2 \\
(7.0)\end{array}$ & $<5$ & $\begin{array}{c}0.003 \pm 0.001 \\
( \pm 0.003)\end{array}$ & $\begin{array}{c}0.07 \pm 0.01 \\
(0.07)\end{array}$ & $\begin{array}{c}0.40 \pm 0.3 \\
(0.29)\end{array}$ & $<0.001$ & $\begin{array}{c}69.2 \pm 0.9 \\
(69.2)\end{array}$ & $<2.5$ & $<1.25$ & $<2.5$ & $<2.5$ \\
\hline $\begin{array}{c}\text { Rejection } \\
(\%)\end{array}$ & - & $>87.9$ & $\begin{array}{c}99.6 \pm 0.2 \\
(99.6)\end{array}$ & $\begin{array}{c}99.6 \pm 0.1 \\
(99.5)\end{array}$ & $\begin{array}{c}85.3 \pm 13.5 \\
(90.0)\end{array}$ & $>99.99$ & $\begin{array}{c}44.6 \pm 10.9 \\
(39.4)\end{array}$ & $>42$ & $>33$ & $>37$ & $>10$ \\
\hline
\end{tabular}


Analyzing Table 13 it is possible to verify that the DK nanofiltration membrane promoted the removal of approximately $100 \%$ of turbidity, total suspended solids (TSS), absorbance and apparent color for all samples. This high efficiency may have been achieved by the size exclusion, since typically the size of these particles is larger than the pore size of the DK membrane. Moreover, this membrane didn't achive good efficiency in the ions removal that can contribute to permeate. This is already expected, that the nanofiltration membrane cannot retain, completely, monovalent ions (TANG; CHONG \& FANE, 2011). But, as can be seen in the Table 13 the greater desalination ability of DK membrane was confirmed even treating water samples with different index quality.

3.3.4.2 Evaluation of the resistances, permeabilities and specific energy demand for the DK membrane of nanofiltration using the surface water

The resistances, permeates flux, resistances, flux decline, and specific energy demand for the permeation of each surface water sample using the DK membrane can be seen in Table 14. 
TABLE 14: Permeate flux, resistences, flux decline, and specific energy consumed for each surface water sample using DK membrane applying 10 bar of tranmembrane pressure and feed flow rate $3.2 \mathrm{~L} / \mathrm{min}$

\begin{tabular}{|c|c|c|c|c|c|c|c|c|c|c|c|}
\hline \multirow[b]{2}{*}{ Samples } & \multirow{2}{*}{$\begin{array}{c}R_{\mathrm{f}} \\
10^{13} \mathrm{~m}^{-1}\end{array}$} & \multirow{2}{*}{$\begin{array}{c}R_{\text {fir }} \\
10^{13} \mathrm{~m}^{-1}\end{array}$} & \multirow{2}{*}{$\frac{R_{\mathrm{fr}}}{10^{13} \mathrm{~m}^{-1}}$} & \multirow{2}{*}{$\frac{\mathbf{J}_{\mathbf{w}}{ }^{\mathbf{a}}}{\left(\mathrm{L} / \mathbf{m}^{2} \cdot \mathbf{h}\right)}$} & \multirow{2}{*}{$\frac{\mathbf{J}_{\mathbf{s d}}{ }^{\mathbf{b}}}{\left(\mathbf{L} / \mathbf{m}^{2} \cdot \mathbf{h}\right)}$} & \multirow{2}{*}{$\frac{\mathbf{J}_{\mathrm{pc}}{ }^{\mathrm{c}}}{\left(\mathrm{L} / \mathbf{m}^{2} \cdot \mathbf{h}\right)}$} & \multirow{2}{*}{$\frac{J_{c c}^{d}}{\left(L / m^{2} \cdot h\right)}$} & \multicolumn{3}{|c|}{$\begin{array}{c}\text { Flux decline type } \\
(\%)\end{array}$} & \multirow{2}{*}{$\frac{\text { SEC }}{\left(k W h \cdot m^{3} m^{2}\right)}$} \\
\hline & & & & & & & & Total & Fouling & $\mathbf{C P}^{\mathrm{e}}$ & \\
\hline 1 & 4.21 & 2.62 & 1.59 & 50.00 & 47.71 & 48.63 & 49.10 & 5 & 3 & 2 & 0.32 \\
\hline 2 & 5.02 & 2.01 & 3.01 & 51.00 & 48.00 & 49.79 & 50.00 & 6 & 4 & 2 & 0.32 \\
\hline 3 & 2.52 & 0.13 & 2.39 & 49.50 & 47.80 & 49.20 & 49.30 & 3 & 0 & 3 & 0.32 \\
\hline 4 & 2.62 & 1.31 & 1.31 & 47.50 & 45.99 & 46.69 & 47.50 & 3 & 2 & 1 & 0.33 \\
\hline 5 & 1.59 & 0.22 & 1.37 & 51.50 & 50.40 & 51.28 & 51.50 & 2 & 1 & 1 & 0.30 \\
\hline
\end{tabular}

ainitial effluent permeate flux;

${ }^{\mathrm{b}}$ final effluent permeate flux;

${ }^{c}$ water permeate flux after physical cleaning

${ }^{\mathrm{d}}$ water permeate flux after chemical cleaning.

epermeate flux decline attributed to the concentration polarization 
The TSS and TOC concentration also influence the type of flux decline and fouling reversibility (Table 14). Greater TOC concentration contributes to flux decline by fouling whereaslow TOC concentration even in case of a higher TSS concentration results in the predominance of fux decline by concentration polarization and in a more reversible fouling. It an also be seen that the membrane fouling does not compromise the membrane SEC.

The lower fouling potential of DK membrane was confirmed in Figure 3 and the fouling degree is dependent on the surface water composition and this relation can be seen in Figure 4.

FIGURE 4: Relation of physico-chemical results of surface water samples with total membrane resistance

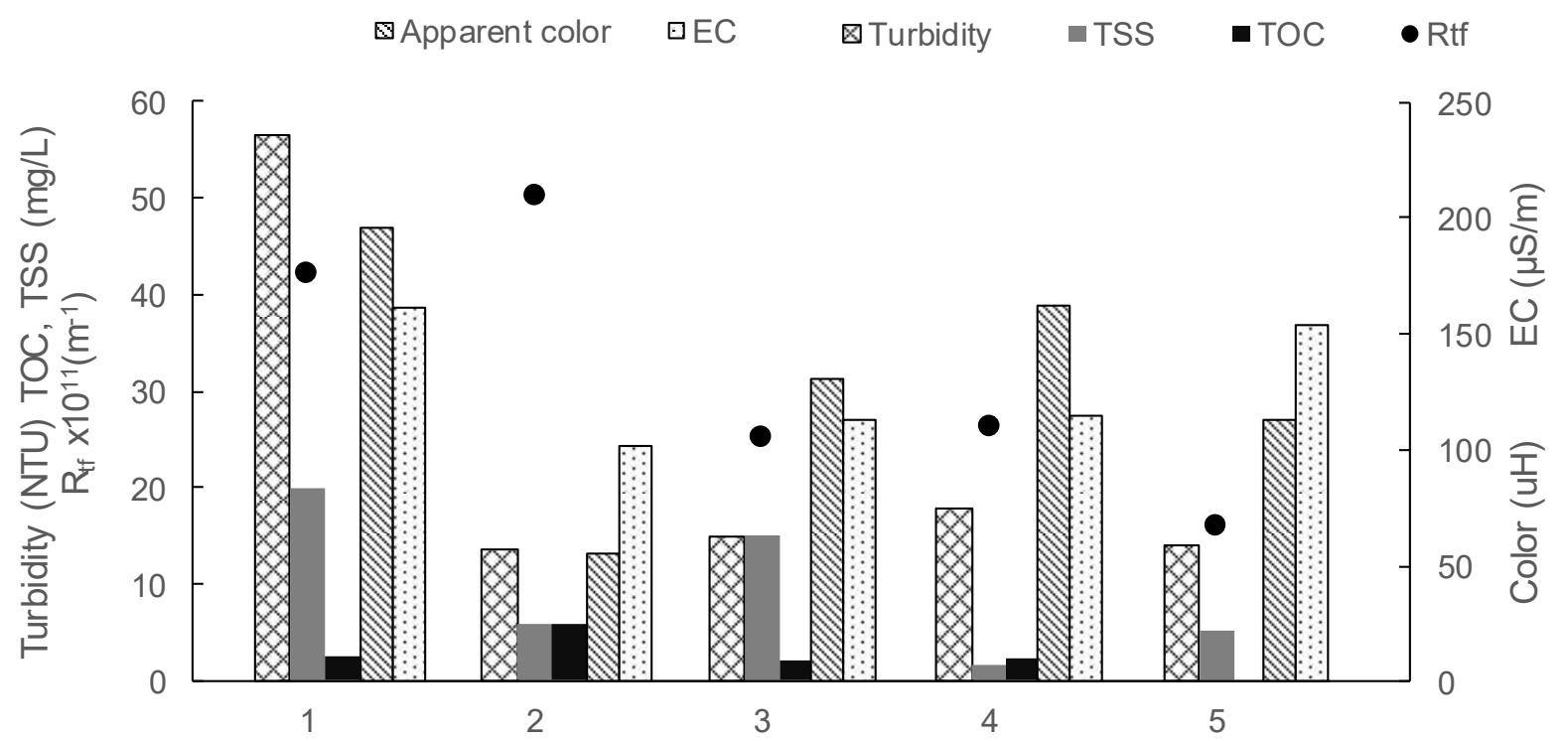

The higher turbidity and TSS concentration influenced in the total fouling resistance, except to sample 2. In this last case the high membrane fouling can be associated with the high TOC concentration and low TSS concentration. The lower solids concentration contributes to the lower cake formation in the membrane surface, leaving the membrane more prone to fouling by adsorption of organic compounds present in higher concentration in this sample.

\subsubsection{Removal comparison of the pharmaceuticals compounds present in the surface water by DK membrane and conventional WTP}

During the quarterly monitoring it was observed another pharmaceutical compound occurrence: Betamethasone. Betamethasone was detected and quantified in four of the five samples collected in concentration range from 20-701.4 ng/L. This pharmaceutical compound isalso in the group of the most frequently prescribed in human medicine and its structure and physico-chemical propertie are show in Table 15. 
TABLE 15: Molecular structure and physico-chemical propertiesof Betamethasone

\begin{tabular}{c|c}
\hline Pharmaceutical compound & Betamethasone \\
\hline Therapeuticclass & Corticosteroid \\
\hline Chemical group & $\begin{array}{c}\text { Analgesicsandanti- } \\
\text { inflammatories }\end{array}$ \\
\hline Molecular formula & $\mathrm{C}_{22} \mathrm{H}_{29} \mathrm{FO}_{5}$ \\
\hline$* *$ Strutural formula & \\
& \\
\hline Molecular weight $(\mathrm{g} / \mathrm{mol})$ & \\
\hline Log Kow & \\
\hline Dissociation constant & \\
\hline Charge at $\mathrm{pH} 7$ & $\mathrm{pKa}=12.42$ \\
\hline$*$ Molar volume $(\mathrm{cm} / \mathrm{mol})$ & $\mathrm{Neutral}$ \\
\hline$*$ Polarizability & 296.00 \\
\hline$* *$ Molecular radius & 39.70 \\
\hline
\end{tabular}

References: * CHEMICALIZE, 2018, ** CHEMICALBOOK, 2018 and ***DRUGBANK, 2018.

Table 16 shows pharmaceutical compounds concentration in the different raw surface water samples, NF membrane permeate, and conventional water treatment. 
TABLE 16: Pharmaceutical compounds removal efficiency that were found in the surface water, using the DK membrane and in water complete cycle treatment

\begin{tabular}{|c|c|c|c|c|c|c|c|c|c|c|c|c|c|c|}
\hline \multirow[b]{2}{*}{$\begin{array}{l}\text { Pharmaceutical } \\
\text { compounds }\end{array}$} & \multicolumn{4}{|c|}{ Surface water } & \multicolumn{5}{|c|}{ DK NF permeate } & \multicolumn{5}{|c|}{ Complete cycle treatment } \\
\hline & $\begin{array}{c}\mathrm{FO} \\
(\mathrm{N}=5)\end{array}$ & $\begin{array}{l}\mathrm{C}(\mathrm{ng} / \mathrm{L}) \\
\min -\max \end{array}$ & $\begin{array}{c}\mathrm{C} \\
(\mathrm{ng} / \mathrm{L}) \\
\text { average }\end{array}$ & $\begin{array}{l}\mathrm{C}(\mathrm{ng} / \mathrm{L}) \\
\text { median }\end{array}$ & $\mathrm{FO}$ & $\begin{array}{l}\mathrm{C}(\mathrm{ng} / \mathrm{L}) \\
\min -\max \end{array}$ & $\begin{array}{c}\mathrm{C} \\
(\mathrm{ng} / \mathrm{L}) \\
\text { average }\end{array}$ & $\begin{array}{c}\mathrm{C} \\
(\mathrm{ng} / \mathrm{L}) \\
\text { median }\end{array}$ & $\begin{array}{l}\text { Rejection } \\
(\%)\end{array}$ & FO & $\begin{array}{l}\mathrm{C}(\mathrm{ng} / \mathrm{L}) \mathrm{min}- \\
\max \end{array}$ & $\begin{array}{l}\mathrm{C}(\mathrm{ng} / \mathrm{L}) \\
\text { average }\end{array}$ & $\begin{array}{c}\mathrm{C} \\
(\mathrm{ng} / \mathrm{L}) \\
\text { median }\end{array}$ & $\begin{array}{l}\text { Rejection } \\
(\%)\end{array}$ \\
\hline Betamethasone & 4 & $20-701.04$ & 246.17 & 131.64 & 2 & $\begin{array}{c}119- \\
172.16\end{array}$ & 145.6 & 145.6 & $>40.85$ & 0 & $<\mathrm{MDL}$ & $<\mathrm{MDL}$ & $<\mathrm{MDL}$ & $>99.00$ \\
\hline Fluconazole & 3 & $\begin{array}{c}227.52- \\
573.76\end{array}$ & 355.89 & 266.4 & 0 & $<\mathrm{MDL}$ & $<\mathrm{MDL}$ & $<\mathrm{MDL}$ & $>99.32$ & 2 & $\begin{array}{c}145.44- \\
151.16\end{array}$ & 148.22 & 148.22 & $>58.35$ \\
\hline Phenylbutazone & 1 & $\begin{array}{l}\text { MQL- } \\
132.72 \\
\end{array}$ & 132.72 & 132.72 & 0 & $<\mathrm{MDL}$ & $<\mathrm{MDL}$ & $<\mathrm{MDL}$ & $>98.19$ & 0 & $<\mathrm{MQL}$ & $<\mathrm{MQL}$ & $<\mathrm{MQL}$ & $>93.97$ \\
\hline Prednisone & 2 & MQL-50.24 & 36.76 & 36.76 & 0 & $<\mathrm{MDL}$ & $<\mathrm{MDL}$ & $<\mathrm{MDL}$ & $>80.25$ & 0 & $<\mathrm{MQL}$ & $<\mathrm{MQL}$ & $<\mathrm{MQL}$ & $>74.23$ \\
\hline
\end{tabular}

MQL (method quantification limits $=8 n g / L)$ FO (frequencies of occurrence); C (Concentration)

MDL (method detection limits for Betamethasone, Fluconazole and Phenylbutazone was $2.4 \mathrm{ng} / \mathrm{L}$ and for Prednisone was $7.2 \mathrm{ng} / \mathrm{L}$ ) 
As previous discussed, the DK membrane showed high pharmaceutical compounds rejection $(>99.32 \%,>98.19 \%$ and $>80.25 \%$ of Fluconazole, Phenylbutazone and Prednisone, respectively) reducing the concentration of pharmaceutical compounds to value lower than method dectation limit, wich was $2.4 \mathrm{ng} / \mathrm{L}$ for Fluconazole and Phenylbutazone and $7.2 \mathrm{ng} / \mathrm{L}$ for Prednisone. The rejection of these three pharmaceutical compounds was not influenced by

the differents characteristics of the surface water. However, the DK membrane showed limited Betamethasone rejection (40.85\%) even this compound having molecular weight and radius higher than membrane cutt-off and pore radius, respectively. Although the neutral compoundsrejection by NF membranes is considered to be predominantly caused by size exclusion, when water is used as feed solution, the existing interactions between non-ionic solutes and membranes may be influenced pharmaceutical compound rejection. In this case, hydrophobic interactions that take place between the fouled membrane surface and such solutes gain predominance (GANIYU et al., 2015). Unlike Fluconazole, which in the pH of the studied water also has a neutral character, the Betamethasone is more hydrophobic. The limited membrane Betamethasone rejection was observed for water samples with low TSS concentration and turbidity.

From the Table 16 it is evident the greater performance of nanofiltration compared to convencional treatment (coagulation/ flocullation/ sand filtration/chlorination). Moreover, membranes were able to reduce the Betamethasone to concentration lower than MDL value. This result suggests that for water with high concentration of Betamethasone the use of conventional treatment as a pre-treatment of NF processes is an alternative to ensure the complete pharmaceutical compound rejection.

\subsection{Conclusions}

Considering all the parameters evaluated in this study, it is noted that the DK membrane presented good drug removal efficiency among the nanofiltration membranes evaluated and results close to the RO process of the BW 30 and SG membranes. However, one parameter that must be evaluate is the energy demand operatingof each membrane, because this implies its use in a real scale.The required pressure in NF systems is considerably lower than RO membranes which subsequently reduce the capital and again, the DK membrane showed good results in the SEC, being behind only the NF 270. Thus, considering the pharmaceutical products retention, desalinationability, permeate flow, membrane fouling and SEC, the DK membrane was chosen to continue the tests evaluating the best operating conditions, and considering transmembrane pressure and flow rate. 
The conventional water treatment was efficient in the evaluated pharmaceutical products removal, except in case the Fluconazole, in wich the station presented anefficiency a little lower than theachieved by membrane. But, it was evident the greater performance of NF compared to convencional treatment since membranes were able to reduce the pharmaceutical compounds to concentration lower than MDL value.

\subsection{References}

APHA - Standard Methods for the Examination of Water and Wastewater. 22 Ed. American Public Health Association, Washington,2012.

BELLONA, C; MARTS, M; DREWES, J.E. The effect of organic membrane fouling on the properties and rejection characteristics of nanofiltration membranes. Sep. Purif. Technol, v. 74, p. 44-54, 2010.

CARRERAS, N. M. et al. The use of sediment colour measured by diffuse reflectance spectrometry to determine sediment sources: Application to the Attert River catchment (Luxembourg), Journal of Hydrology, v. 382, p. 49-63, 2010.

CETESB 2016 Qualidade das Águas Doces no Estado de São Paulo | Apêndice E Significado Ambiental e Sanitário das Variáveis de Qualidade.Available in: 52http://cetesb.sp.gov.br/aguasinteriores/wpcontent/uploads/sites/12/2017/11/Ap\%C3\%AAnd ice-E-Significado-Ambiental-e-Sanit\%C3\%A1rio-das-Vari\%C3\%A1veis-de-Qualidade2016.pdf. Accessed in Dez, 2017.

CHEMICALBOOK 2018Available in $<$ http://www.chemicalbook.com $>$ Accessed in January 2018.

CHEMICALIZE 2018 Available in $<$ https://chemicalize.com/> Accessed in January 2018.

COMERTON, A.M; ANDREWS, R.C; BAGLEY, D.M; HAO, C., 2008. The rejection of endocrine disrupting and pharmaceutically active compounds by NF and RO membranes as afunction of compound and water matrix properties.Journal of Membrane Science, v. 313,p. $323-335,2008$.

DEBLONDE, T; COSSU-LEGUILLE, C; HARTEMANN, P. Emerging pollutants in wastewater: a review of the literature. Int. J. Hyg. Environ. Health, v. 214,p.442-448, 2011.

DOEDERER, K; FARRÉ, M. J; PIDOU, M; WEINBERG, H, S; GERNJAK W. Rejection of disinfection by-products by RO and NF membranes: influence of solute properties and operational parameters. Journal of Membrane Science, v.467, p.195-205, 2014.

DRUGBANK < https://www.drugbank.ca/drugs/DB00635>Accessed in January 2018.

GARCIA-IVARS J; DURÁ-MARÍA J; MOSCARDÓ-CARREÑO C; CARBONELLALCAINA C; ALCAINA-MIRANDA MI; IBORRA-CLAR MI. Rejection of trace pharmaceutically active compounds present in municipal wastewaters using ceramic fine ultrafiltration membranes: Effect of feed solution $\mathrm{pH}$ and fouling phenomena. Separation and Purification Technology, v. 175, p. 58-71, 2017. 
GEANIYU, S.O; HULLEBUSCH, E.D.V; CRETIN, M; ESPOSITO, G; OTURAN, M.A, Coupling of membrane filtration and advanced oxidation processes for removal of pharmaceutical residues: a critical review. Sep. Purif. Technol v. 156 , p. 891-914, 2015.

HUERTA-FONTELA, M; GALCERAN, M. T; VENTURA, F. Occurrence and removal of pharmaceuticals and hormones through drinking water treatment. Water research,v.45, p.1432-1442, 2011.

ISRAELACHVILI J N. Intermolecular and Surface Forces. San Francisco: Academic Press, 2015.

KONG F X; YANG H W; WANG X M; XIE Y F. Assessment of the hindered transport model in predicting the rejection of trace organic compounds by nanofiltration. Journal of Membrane Science,v. 498, p.57-66,2015.

LEE, S; LEE, C. H. Effect of membrane properties and pretreatment on flux and NOM rejection in surface water nanofiltration. Separation and Purification Technology, v. 56, p. 1$8,2007$.

LIN, Y.L; LEE, C.H. Elucidating the rejection mechanisms of PPCPs by nanofiltration and reverse osmosis membranes, Ind. Eng. Chem. Res, v.53, p.6798-6806, 2014.

MARYAM, B; USTUN, S; BUYUKGUNGOR, H. Evaluation of membranes as promising technique for reclamation and reuse of wastewater. European Water, v. 58, p.15-19, 2017.

NGHIEM, L D; SCHÄFER, A I. Adsorption and transport of trace contaminant estrone in NF/RO membranes. Environmental Engineering Science, v. 19, p. 441-451, 2002.

PIRATOBA, A. R. A.; RIBEIRO, H. M. C; MORALES, G. P.; GONÇALVES, W.G, Caracterização de parâmetros de qualidade da água na área portuária de Barcarena, PA, Brasil, Ambiente \& Água -Na Interdisciplinary Journal of Applied Science, v.12, p.435-456, 2017.

PIRH - Plano Integrado de Recursos Hídricos da Bacia Hidrográfica do Rio Doce e Planos de Ações para as Unidades de Planejamento e Gestão de Recursos Hídricos no Âmbito da Bacia do Rio Doce, 2010. Available in $<$ http://www.cbhdoce.org.br//wpcontent/uploads/2016/12/PIRH_Doce_Volume_I.pdf $>$ Accessed in February 2018.

RAHMAN, M. F; YANFUL, E. K; JASIM, S. Y. Endocrine disrupting compounds (EDCs) and pharmaceuticals and personal care products (PPCPs) in the aquatic environment: implications for the drinking water industry and global environmental health. Journal of water and health, v.7, p. 224-243, 2009.

RUBIA, A; RODRIGUEZ, M; LEON, V; PRATS,D. Removal of natural organic matter and THM formation potential by ultra- and nanofiltration of surface water, Water Res, v. 42 , p. 714-722, 2008.

SCHÄFER, A. I; AKANYETI, I; SEMIÃO, A. J. C. Micropollutant sorption to membrane polymers: a review of mechanisms for estrogens. Advances in Colloid \& Interface Science, v. 164, p.100-117, 2011. 
TANG , C. Y; KWON,Y.N; LECKI, J. O. Effect of membrane chemistry and coating layer on physiochemical properties of thin film composite polyamide RO and NF membranes II. Membrane physiochemical properties and their dependence on polyamide and coating layers. Desalination, v. 242, p. 168-182, 2009.

TANG, C.Y; CHONG, T.H; FANE, A.G. Colloidal interactions and fouling of NF and RO membranes: A review. Adv. Colloid Interface Sci, v. 164, p. 126-143,2011.

TU, K. L; NGHIEM, L. D; CHIVAS, A. R, Coupling effects of feed solution $\mathrm{pH}$ and ionic strength on the rejection of boron by NF/RO membranes. ChemicalEngineeringJournal, v.168, p. 700-706, 2011.

TUNDISI, J. G; MATSUMURA TUNDISI, T. Limnologia.São Paulo: Oficina de Textos, p. $632,2008$.

URTIAGA, A.M; PÉREZ,G; IBÁÑEZ,R;ORTIZ,I. Removal of pharmaceuticals from a WWTP secondary effluent by ultrafiltration/reverse osmosis followed by electrochemical oxidation of the RO concentrate. Dasalination, v.331, p. 26-34, 2013.

USEPA- United States Environmental Protection Agency - Secondary maximum contaminant levels: a strategy for drinking water quality and consumer acceptability. 2015. Available in:< http://www.waterrf.org/PublicReportLibrary/4537.pdf>, Accessed in: December,2017.

VERLIEFDE, A. R;CORNELISSEN, E. R; HEIJMAN, S. G. J; PETRINIC, I; LUXBACHER, T; AMY, G. L; VAN DIJK, J. C. Influence of membrane fouling by (pretreated) surface water on rejection of pharmaceutically active compounds (PhACs) by nanofiltration membranes. JournalofMembrane Science, v. 330, p.90-103, 2009.

VON SPERLING, M. Estudos de modelagem da qualidade da água de rios. Belo Horizonte: UFMG, v. 7, p.452, 2007.

WATTS, C; MAYCOCK, D; CRANE, M; FAWELL, J; GOSLAN, E. Desk Based Review of Current Knowledge on Pharmaceuticals in Drinking Water and Estimation of Potential Levels and Final Report. Defra Project Code: CSA 7184/WT02046/ DWI70/2/213, 2007.

YOON, S. H; LEE, C. H. Effect of calcium ion on the fouling of nanofilter by humic acid in drinking water production, Wat. Res, v. 32, p. 2180-2186, 1998.

YOON, Y; LUEPTOW, R. M. Removal of organic contaminants by RO and NF membranes. Journal of Membrane Science,v.261, p. 76-86, 2005.

ZHANG, Y; GEIßEN, S. U; GAL, C. Carbamazepine and diclofenac: removal in wastewater treatment plants and occurrence in water bodies.Chemosphere, v.73, p. 1151-1161, 2008.

ZUIN, V. G; IORIATTI, M. C. S; MATHEUS C. E. O emprego de parâmetros físicos e químicos para a avaliação da qualidade de águas naturais: uma proposta para a educação química e ambiental na perspectiva CTSA. Química Nova na Escola, v. 31, 2009. 


\section{EVALUATION OF THE BEST TRANSMEMBRANE PRESSURE AND FEED FLOW RATE TO DK MEMBRANE}

\subsection{Introduction}

The presence of emerging pollutants in nature has gained a focus from the scientific community due to the potential risks to human health and the ecosystem associated with drugs interactions with the natural environment. This constant pharmaceutical products occurrencein aquatic environment is facilitated by the drugs ingestion (JELIC et al., 2011). The first metabolic process is the oxidation or reduction, which occurs in the liver making the molecule more polar than its parent compound. After the acetylation and sulphation step, the hydrophilic characteristic is attributed to these metabolites making them more soluble in water (LÓPEZ-SERNA et al., 2012). Thus, these compounds are eliminated through feces and urine following the sewage collection network up to the municipal waste water treatment plant (WWTP) (TAHERAN et al., 2016; YAN et al., 2014).

The membrane separation process using nanofiltration is an increasingly employed technology becoming also increasingly reliable and affordable for the production of high quality water from unconventional sources such as surface water contaminated by micropollants (TAHERAN et al., 2016). The retention of the compounds that are present in the feed by nanofiltration membranes can happen through three coexisting separation mechanisms, which are: the exclusion mechanism, the electrostatic repulsion and the physicochemical interaction occurring at the same time between the compounds of the solution to be treated and the surface of the membrane (RADJENOVIC et al., 2008; KUDLEK, BOHDZIEWICZ \& DUDZIAK, 2015).

In spite of having a lower retention for some compounds, DK nanofiltration membrane presented satisfactory results, ranging from $64 \%$ to $99 \%$, for the micro contaminants removal in aqueous matrices (DOLAR \& KOŠUTIĆ, 2013). However, according to Al Manun et al (2017) the greatest challenge in the application of the pressure-driving membrane, which includes nanofiltration, is the reduction in the efficiency of the solutes retention and the decrease in the permeate flow due fouling.

Fouling can be defined as the deposition of retained particles, colloids, macromolecules, among others, on the surface or inside the pores of the membranes (MULDER, 1996). The fouling can be formed by the adsorption processes (BANERJEE \& DE, 2010), pore blockade (MATTARAJ et al., 2011) and cake formation (HOEK \& ELIMELECH, 2003). The 
characteristic fouling occurrenceto the nanofiltration membrane are mainly related to the NF cake formed by charged colloidal substances that precipitate on the surface of the membrane and the concentration polarization (CP) due to the retained ions (AL MANUN et al., 2017). The adsorption of the compounds present in the feed can occur on the surface of the membrane or even in the pores reducing them in size, consequently contributing also to thepermeate flowdecline. The adsorption together with the precipitation of elements on the surface of the membrane form the cake that can alter the permeability of the membrane and its selectivity, since the particles in the surface end up being added to the others by intermolecular interactions (GARCÍA-MARTÍN et al., 2010; ANDRADE, 2011). The concentration polarization occurs with the accumulation of the retained, or partially retained, solutes on the surface of the membrane. Thus, the concentration of these solutes on the surface of the membrane is greater than the concentration within the feed, providing diffusionin the direction of the membrane surface to the solution (RICHARDS, 2012).

However, this phenomenon may be reversible and can be controlled by the operational conditionsmonitoring, such as the use of turbulence promoters (HABERT et al., 2006; ANDRADE 2011). Some research shows that an increased feed flow rate contributes positively to remove solids present in the feed, in the gel layer. Thus, increasing the velocity of flow decreases, consequently, the increasing diffusion of the solutes back to the volume, causing a general reduction of the effect of the polarization concentration which resulted in a smaller permeate flowdecline.

The control of the transmembrane pressure is essential as it affects the permeation rate. Using higher pressures, the applied force in the feed so that its solvent crosses the membrane is larger thus producing a greater permeate flow. However, this force may also contribute to increase the effect of the polarization concentration favoring the accumulation of solutes on the surface of the membrane (ABDELRASOUL, DOAN \& LOHI, 2013).

Thus, this study aims to analyze the best operating conditions varying the transmembrane pressure and the feed flow rate aiming to evaluate the fouling effect observing each condition using the NF membrane (Desal 5-DK). For theseanalysis, it was evaluated the permeate flux, membrane resistance and its pharmaceutical compoundsretention efficiency. For this step, it was used the $4^{\text {th }}$ surface water sample, which was collected in January 2017. 


\subsection{Materials and methods}

\subsubsection{Water source}

River Doce represents a source of drinking water for 400.000 inhabitants in the Governador Valadares city that discharge all sewage, that is producted in the city, without previous treatment into in this river, until now. Because of this, Doce river was selected to serve as a background matrix to evaluate the pharmaceutical compounds rejection. The samples were collected inthe geographical coordinate $18^{\circ} 51^{\prime} 50.45$ "S and 41 $56^{\prime} 46.86^{\prime \prime} \mathrm{W}$. One pharmaceutical compound had been detected in this $4^{\text {th }}$ surface water sample as described in Chapter 2 of this study: Betamethasone (ng/L).

\subsubsection{Membrane}

The technical properties of DK nanofiltration membrane, supplied by the GE Osmonics Company can be seen in the Table 17.

TABLE 17: Technical properties of DK nanofiltration membrane

\begin{tabular}{c|c|c|c|c|c|c}
\hline Membrane & $\begin{array}{c}\text { Poresize } \\
(\mathrm{mm})\end{array}$ & $\begin{array}{c}\text { Contact } \\
\text { angle }\left(^{\circ}\right)\end{array}$ & $\begin{array}{c}\text { Zeta } \\
\text { potential } \\
\mathrm{pH} \mathrm{9} \\
(\mathrm{mV})\end{array}$ & $\begin{array}{c}\text { Roughness } \\
(\mathrm{nm})\end{array}$ & $\begin{array}{c}\text { Molecular } \\
\text { weight } \\
\text { cut-off } \\
(\mathrm{MWCO})\end{array}$ & Material \\
\hline $\begin{array}{c}\text { GE } \\
\text { DK }\end{array}$ & 0.76 & $40.6 \pm 5.2$ & -18.5 & $16.4 \pm 3.1$ & $150-300$ & Polyamide \\
\hline
\end{tabular}

Reference: TANG et al., 2009.

\subsubsection{Experimental set-up and methods}

Prior to each experiment, membrane was first cleaned by ultrasonication with $0.4 \%$ sodium hydroxide solution followed by ultrasonic ation with $2 \%$ citric acid solution, for 20 min each, and compacted by filtering deionised water at 10 bar for at least $2 \mathrm{~h}$ until a stable water flux was reached. After that, experiments consisted in filtration runs of $2 \mathrm{~h}$ with water of the Doce river with feed flow rate of $2.4 \mathrm{~L} / \mathrm{min}$ and varying the pressure in 10;8; 6 and 4 bar. After establishing the best operating pressure, the pressure was set and the flow rate of the feed was varied in 0.8: 1.2: 2.4 and $3.2 \mathrm{~L} / \mathrm{min}$. These two steps were carried out bath mode where by the concentrate and permeate was recirculated into the feed tank. The permeate flow rate was determined by measuring the volume of permeate collected at regular time intervals. After each set of experiments for a given membrane, the membrane was rinsed with deionized water 
with cross flow rate of $1.2 \mathrm{~L} / \mathrm{min}$ and cleaned by ultrasonication with $0.4 \%$ sodium hydroxide solution followed by ultrasonication with $2 \%$ citric acid solution, for 20 min each.

\subsubsection{Calculations}

The permeate flux $(\mathrm{J})$ was measured in liters per square meter per hour $\left(\mathrm{L} / \mathrm{m}^{2} . \mathrm{h}\right)$ applying the Eq. (1).

$l(T)=\frac{\Delta V}{A m \times \Delta t}$

Where $\mathrm{J}(\mathrm{T})$ is the permeate flux at a temperature $\mathrm{T}, \Delta \mathrm{V}$ is the total volume of the permeate (L) collected in the $\Delta \mathrm{t}$, the filtration time ( $\mathrm{min}$ ), and Am is the effective membrane filtration area $\left(\mathrm{m}^{2}\right)$.

Flux data were normalized at $25{ }^{\circ} \mathrm{C}$ using a correction factor calculated from the ratio of water viscosity at the permeation temperature and water viscosity at $25^{\circ} \mathrm{C}$ as shown in Eq.

$J\left(25^{\circ} \mathrm{C}\right)=J(T) \cdot \frac{\mu(T)}{\mu\left(25^{\circ} \mathrm{C}\right)}$

Where $\mathrm{J}(\mathrm{T})$ is the permeate flow at the permeation temperature, obtained in Equation $1, \mu(T)$ is the dynamic viscosity of the water at the permeation temperature, $\mu\left(25^{\circ} \mathrm{C}\right)$ is the dynamic viscosity of the water at $25^{\circ} \mathrm{C}$ and $\mathrm{J}\left(25^{\circ} \mathrm{C}\right)$ is the permeate flux corrected to $25^{\circ} \mathrm{C}$.

The observed rejection was calculated using Eq. (3), as follows:

$R(\%)=\frac{c_{f}-c_{p}}{C_{f}} \times 100$,

Where $C_{f}$ and $C_{p}$ represent the solute content in the feed and permeate streams, respectively.

According to the simplified resistance-in-series model, the total filtration resistance could be divided into membrane resistance and fouling resistance. The membrane resistance to filtration $\left(R_{M}\right)$ was determined from Eq. (4):

$R_{M}=\frac{1}{K \cdot \mu\left(25^{\circ} \mathrm{C}\right)}$ 
The total flux decline (FD) was also calculated, as follows in Eq.(5)

$F D=\frac{\left(J_{w}-J_{s d}\right)}{J_{w}}$

Where $J_{w}$ is the volumetric permeate flux of pure water of the membrane before effluent filtration.

Flux decline can be attributed to concentration polarization $(C P)$ and fouling $(F)$; thus, the flux decline due to $C P$ was obtained using Eq. (6), as follows:

$C P=\frac{\left(J_{p c}-J_{s d}\right)}{J_{w c}}$,

Where $J_{s d}$ is the volumetric water flux of the physically cleaned membrane after effluent filtration.

The flux decline due to fouling $(F)$ was obtained using Eq. (7), as follows:

$F=\frac{\left(J_{w}-J_{s d}\right)}{J_{w}}$

The specific energy consumption SEC $\left(\mathrm{kWh} / \mathrm{m}^{3}\right.$ of permeate) was calculated according to Eq.8.

$\mathrm{SEC}=\frac{\mathbf{w}}{\mathbf{Q}_{\mathbf{P}}}$

$\mathrm{W}=\frac{\Delta \mathbf{P} \times \mathbf{Q}_{\mathrm{F}}}{3.6 \times 10^{6}}$

The recovery rate $(\alpha)$ is defined by Equation (10):

$\alpha=\frac{\mathrm{Qp}}{\mathrm{Qa}} * 100$

Where $\mathrm{Q}_{\mathrm{p}}$ and $\mathrm{Q}_{\mathrm{a}}$ are respectively the permeate and feed volumetric flow in a given filtration step. Thus, the maximum recovery rate is the percentage of the feed that can be converted to permeate without decreasing the physicochemical quality and pharmaceutical compounds retention without a large decay of the flux caused by membrane fouling.

Where $\mathrm{W}$ is the rate of work done by the pump $(\mathrm{kWh} / \mathrm{s}), \Delta P$ is the difference between the feed pressure at the entrance of the membrane and the pressure of the raw water, which is 
assumed to be equal to the atmospheric pressure $\left(\mathrm{N} / \mathrm{m}^{2}\right)$, and $Q_{F}$ and $Q_{P}$ are the feed and permeate flow rates $\left(\mathrm{m}^{3} / \mathrm{s}\right)$, respectively.

\subsubsection{Analytical methods}

The collected samples and permeates were analyzed accordingto the following parameters: Turbidity (Hach 2100AN Turbidimeter) (Method 2130B), pH (Qualxtron QX 1500 pH meter) (Method 4500B), absorption at $254 \mathrm{~nm}$ and apparent color (Hach Spectrophotometer DR 2800) (Method 2120B), total suspended solids (TSS) (Method 2540B), total organic carbon (Shimadzu TOC-V CNP TOC Analyzer) (Method 5310), conductivity (Hanna HI 9835 Conductivity Meter) (Method 2510 B) and ion scan (ICP-OS) (Method 4110B). These analyses were made in triplicates according to the recommendations of Standard Methods for the Examination of Water and Wastewater (APHA 2012).

Pharmaceutical compounds were analyzed using a HPLC (DGU/20A3 Prominence, Shimadzu, Japan) coupled to the micrOTOF-QII mass spectrometer (Bruker) with an electrospray ionization source (ESI) in positive mode. The detection limit for each pharmaceutical compound was $8 \mathrm{ng} / \mathrm{L}$. The uncertainty of estimates is of $1 \%$ according to a validation method of the analysis protocol. Recoveries are between 86 and $100 \%$ but are compensated by the calibration, which is processed the same way as the samples. Water samples were previously filtered in $0.45 \mu \mathrm{m}$ hydrophilic PVDF filter. Analytes were isolated from water samples (1 L) in two steps, firstly without $\mathrm{pH}$ adjustment $(\mathrm{pH} 7)$ and then with $\mathrm{pH}$ adjustment to 2 by adding 0.002 mols $/ \mathrm{L} \mathrm{H}_{2} \mathrm{SO}_{4}$ solution, using a polymeric $\mathrm{C} 18 / 18 \%$ cartridge (500 mg/6 mL - Applied Separations) preconditioned with $5 \mathrm{~mL}$ of methanol and 5 $\mathrm{mL}$ of ultra pure water, and then eluted with methanol using Aspec Gilson GX-271 Liquid Handler. Separation was achieved on a Shim-pack XR-ODS C18 column $(2.0 \mathrm{~mm} ; 50 \mathrm{~mm}$ and $2.0 \mu \mathrm{m}$; Shimadzu, Japan) with the mixture of $0.1 \%$ of formic acid water and methanolas the mobile phase. The flow rate and injection volume were $0.1 \mathrm{~mL} / \mathrm{min}$ and $10 \mu \mathrm{L}$, respectively. The mobile phase gradient followed an isocratic method using $95 \%$ of methanol for 15 minutes. 


\subsection{Results}

\subsubsection{Pressure evaluation}

4.3.1.1 Evaluation of the resistances, permeabilities and specific energy demand for each pressure evaluated

The evaluation considered the permeatesflux, resistances, flux decline, andspecific energy demand for each pressure can be seen in the Table 18 . 
TABLE 18: Permeates flux, resistances, flux decline, and specific energy consumed during nanofiltration varying the transmembrane pressures at $4 ; 6 ; 8$ and 10 bar with the feed flow rate fixed in $2.4 \mathrm{~L} / \mathrm{min}$

\begin{tabular}{|c|c|c|c|c|c|c|c|c|c|c|c|}
\hline \multirow{2}{*}{$\begin{array}{c}\text { Pressure } \\
\text { (bar) }\end{array}$} & $\mathbf{R}_{\mathbf{f}}$ & $\mathbf{R}_{\text {fir }}$ & $\mathbf{R}_{\mathrm{fr}}$ & $\mathbf{J}_{\mathbf{w}}{ }^{\mathrm{a}}$ & $\mathbf{J}_{\mathbf{s d}} \mathbf{b}^{\mathbf{b}}$ & $\mathbf{J}_{\mathbf{p c}} \mathbf{c}^{\mathbf{c}}$ & $\mathbf{J}_{c c}{ }^{d}$ & \multicolumn{3}{|c|}{$\begin{array}{c}\text { Flux decline type } \\
(\%)\end{array}$} & SEC \\
\hline & $10^{13} \mathrm{~m}^{-1}$ & $10^{13} \mathrm{~m}^{-1}$ & $10^{13} \mathrm{~m}^{-1}$ & $\left(\mathbf{L} / \mathbf{m}^{2} . \mathbf{h}\right)$ & $\left(\mathbf{L} / \mathbf{m}^{2} . h\right)$ & $\left(\mathbf{L} / \mathbf{m}^{2} \cdot \mathbf{h}\right)$ & $\left(\mathbf{L} / \mathbf{m}^{2} . \mathbf{h}\right)$ & Total & Fouling & $\mathbf{C P}^{\mathrm{e}}$ & $\left(k W h \cdot m^{3} m^{2}\right)$ \\
\hline 10 & 0.41 & 0.26 & 0.15 & 50.00 & 47.71 & 48.63 & 49.10 & 5 & 3 & 2 & 0.32 \\
\hline 8 & 0.63 & 0.28 & 0.35 & 40.00 & 37.75 & 39.06 & 39.53 & 6 & 3 & 3 & 0.40 \\
\hline 6 & 1.42 & 1.03 & 0.39 & 31.00 & 28.11 & 28.91 & 31.25 & 10 & 7 & 3 & 0.54 \\
\hline 4 & 2.09 & 1.13 & 0.96 & 21.20 & 19.18 & 20.10 & 20.12 & 10 & 5 & 5 & 0.80 \\
\hline
\end{tabular}

initial effluent permeate flux;

${ }^{\mathrm{b}}$ final effluent permeate flux;

${ }^{c}$ water permeate flux after physical cleaning

${ }^{\mathrm{d}}$ water permeate flux after chemical cleaning

epermeate flux decline attributed to the concentration polarization 
As expected, the 10 bar pressure results in highest permeate flow. In addition, applying this pressure also resulted in a smaller decline in permeate flux caused by reversible fouling. The same behavior occurred with the resistances, since the higher transmembrane pressure used resulted in lower resistance values, which is also explained by the lower deposition of solutes on the membrane surface due to the shear force of the turbulent flow.

As the feed rate was set at all pressures evaluated at $2.4 \mathrm{~L} / \mathrm{min}$, the SEC calculations varied due to the permeate flux productedfor each pressure, which parameter is inversely proportional to the SEC. Thus, when the highest pressure (10 bar) was applied, the highest flow rate was also obtained thus achieving the lowest energy demand. According to Koyuncu et al (2000), for NF membranes the energy demand to permeate productionnormally decreases if increases the transmembrane pressure, fact that explains what was observed for the SEC during the variation of pressures from 4 to 10 bar.

\subsubsection{Physico-chemical analysis of surface water}

The relationship of the physical and chemical parameters of the surface water with the permeate flux and total resistance, as well as the efficiency of these parameters removal for each pressure evaluated in this study can be observed in Figure 5.

FIGURE 5: Physico-chemical parameters removal efficiency for each transmembrane pressure (TMP) evaluated and the relation of these parameters with the permeate flux and total resistance

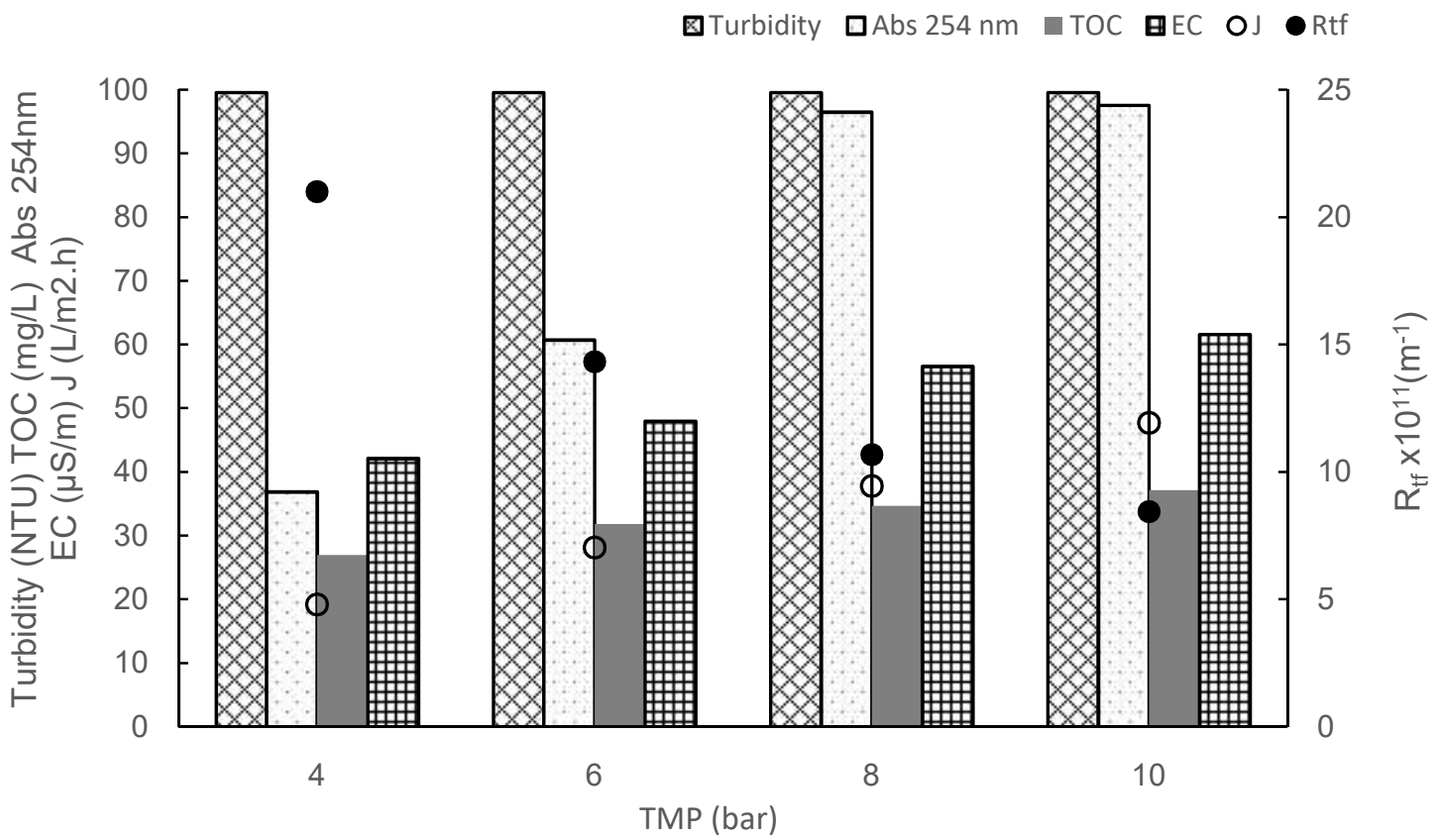

Evaluating the physical and chemical results of the surface water, permeate producted at each evaluated pressure shows a better efficiency in the solutes retention applying the 10 bar 
transmembrane pressure. The absorbance and turbidity removal applying the 10 bar pressure was almost $100 \%$. The apparent color and total suspended solids, which are parameters directly related to turbidity and absorbance, were also almost completely removed by applying 10 bar of TMP. Due to nanofiltration membrane cannot retain, completely, monovalent ions, the removal of conductivity did not reach high removal values for all pressures evaluated (TANG; CHONG \& FANE, 2011). However, the most effective removal of this parameter was obtained by applying the 10 bar transmembrane pressure.

\subsubsection{Evaluation of pharmaceutical compound retention varying the transmembrane pressure}

The results of retention of Betamethasone using the DK membrane varying the transmembrane pressures can be seen in Table 19.

TABLE 19: Pharmaceutical compound occurrence in the surface water and the permeates of each evaluated transmembrane pressure

\begin{tabular}{cc}
\hline Pressure (bar) & $\begin{array}{c}\text { Concentration of } \\
\text { Betamethasone (ng/L) }\end{array}$ \\
4 & $<\mathrm{MQL}$ \\
6 & $<\mathrm{MQL}$ \\
8 & $<\mathrm{MQL}$ \\
10 & $<\mathrm{MQL}$ \\
$M Q L=8 n g / L$ & Surface water
\end{tabular}

It is known that the accumulation of organic matter in the surface of the membrane can carry its surface negatively, which would facilitate the adsorption of the positive compounds and increase the negative elements rejection. This is because organic matter presents negative charge and, according to Coulomb's Law, elements that were charged electrically with equal charges are repulsed and elements that present opposite charges are attracted. Thus, the pharmaceutical compounds that present the highest $\mathrm{pKa}$, which have characteristics of less acidic compounds, tend to be removed, as the case of Betamethasone that present a $\mathrm{pKa}$ of 12.42. However, to deepen this discussion of the interaction of the solutes with the membrane, it is necessary to investigate the membrane surface before and after the MSP.

\subsubsection{Choice of the best operating pressure}

The pressure of 10 bar presented the highest permeability and lowest SEC. In addition, this pressure presented the best results of the physical and chemical parameters of permeate when compared to the surface water. Moreover, 10 bar, like the others pressures that were 
evaluated, presented complete Betamethasone removal that was quantified in the $4^{\text {th }}$ surface water sample.

\subsubsection{Feed flow rate evaluation}

4.3.2.1 Evaluation of the resistances, permeabilities and specific energy demand for each feed flow rate evaluated

The results of permeates flux, resistances, flux decline, and specific energy demand for each feed flow rate as can be seen in the Table 20. 
TABLE 20: Permeates flux, resistances, flux decline and specific energy consumed during nanofiltration varying the feed flow at $0.8 ; 1.2 ; 2.4$ and $3.2 \mathrm{~L} / \mathrm{min}$ at 10 bar of pressure

\begin{tabular}{|c|c|c|c|c|c|c|c|c|c|c|c|}
\hline \multirow{2}{*}{$\begin{array}{c}\text { Feed } \\
\text { rate } \\
(\mathrm{L} / \mathrm{min})\end{array}$} & \multirow{2}{*}{$\frac{R_{f}}{10^{13} \mathrm{~m}^{-1}}$} & \multirow{2}{*}{$\frac{R_{\mathrm{fir}}}{10^{13} \mathrm{~m}^{-1}}$} & \multirow{2}{*}{$\frac{R_{\mathrm{fr}}}{10^{13} \mathrm{~m}^{-1}}$} & \multirow{2}{*}{$\frac{J_{w}{ }^{a}}{\left(L / m^{2} \cdot h\right)}$} & \multirow{2}{*}{$\frac{\mathbf{J}_{\text {sd }}{ }^{b}}{\left(\mathrm{~L} / \mathbf{m}^{2} \cdot \mathbf{h}\right)}$} & \multirow{2}{*}{$\frac{\mathbf{J}_{\mathbf{p c}} \mathbf{c}}{\left(\mathbf{L} / \mathbf{m}^{2} \cdot \mathbf{h}\right)}$} & \multirow{2}{*}{$\frac{\mathbf{J}_{\mathrm{cc}}{ }^{\mathbf{d}}}{\left(\mathrm{L} / \mathbf{m}^{2} \cdot \mathbf{h}\right)}$} & \multicolumn{3}{|c|}{ Flux decline type (\%) } & \multirow{2}{*}{$\frac{\mathrm{SEC}}{\left(\mathrm{kWh} \cdot \mathrm{m}^{3} \mathrm{~m}^{2}\right)}$} \\
\hline & & & & & & & & Total & Fouling & $\mathbf{C P}^{\mathrm{e}}$ & \\
\hline 0.8 & 0.56 & 0.21 & 0.35 & 36.90 & 35.18 & 36.31 & 36.86 & 5 & 2 & 3 & 0.30 \\
\hline 1.2 & 0.44 & 0.22 & 0.22 & 37.00 & 35.58 & 36.31 & 36.94 & 4 & 2 & 2 & 0.30 \\
\hline 2.4 & 0.81 & 0.20 & 0.61 & 37.10 & 35.35 & 36.86 & 36.95 & 5 & 1 & 4 & 0.29 \\
\hline 3.2 & 0.26 & 0.13 & 0.13 & 37.50 & 35.99 & 36.69 & 37.50 & 4 & 2 & 2 & 0.29 \\
\hline
\end{tabular}

initial effluent permeate flux;

${ }^{\mathrm{b}}$ final effluent permeate flux;

${ }^{c}$ water permeate flux after physical cleaning

water permeate flux after chemical cleaning

epermeate flux decline attributed to the concentration polarization 
In relation to the resistances, it is noticed that when increasing the flow rate of the feed, the resistances decreased significantly. Therefore, the combination of the higher pressure with the higher flow rate resulted in the hydrodynamic condition of greater shear force, making it difficult to deposition of solutes in the membrane, reducing the resistance and consequently increasing the permeability.

\subsubsection{Analysis of the physical andchemical parameters for each applied feed rate}

The results of the physical and chemical analyzes as well as the relation of these parameters with the flow and total resistance in each feed flow can be observed in Figure 6.

FIGURE 6: Physical and chemical analyzes as well as the relation of these parameters with the flow and total resistance varying the feed flow

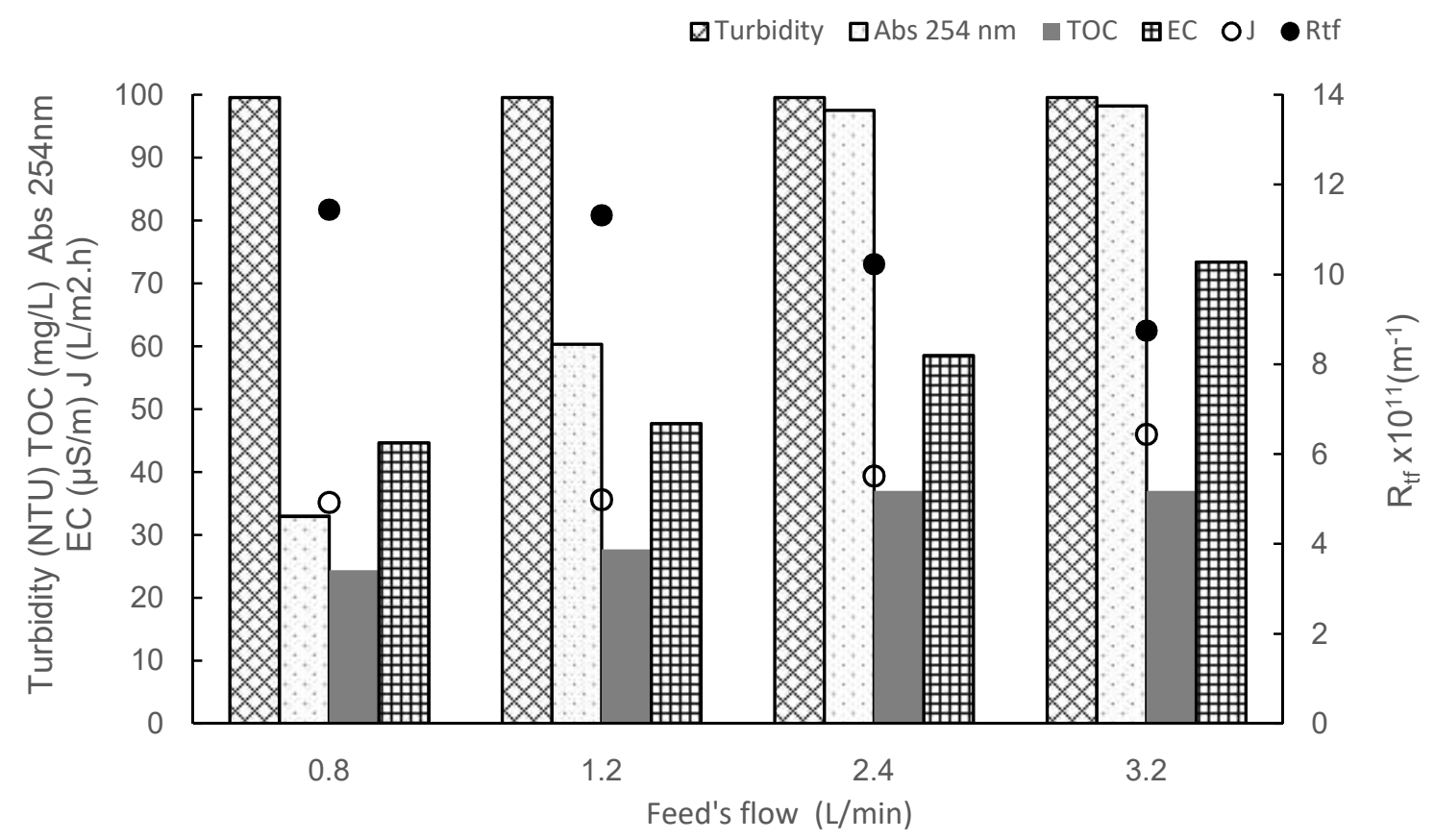

Analyzing Figure 6, it can be seen that the permeate physico-chemical results, that were obtained using the highest flow rate, presented the best retention efficiency for all parameters that were evaluated. Moreover, this feed flow achieved the best permeates flow result and total resistance. The explanation for these results is the same reason that led to the greater pressure, applied in the previous section of this study, to obtain the best results. The higher feed flow used caused a greater turbulence between the feed and the surface, increasing the shear force between them, which hinders the deposit of solute on the surface of the membrane. Thus, with the least accumulation of elements on this surface the polarization concentration, as well as the other types of fouling tend to be smaller, thus reducing the total resistance and increasing the flux of the permeate. In addition, this lower deposition of organic matter and other elements on the membrane surface contributes to decrease the mass 
transfer by diffusion, which makes retention of the parameters evaluated in this study more efficient.

\subsubsection{Evaluation of pharmaceutical products retention varying the feed flow}

Analyzing Table 21, it can be seen that all of the flow velocities removed Betamethasone that was present in the surface water.

TABLE 21: Pharmaceutical compound occurrence in the surface water and the permeates of each evaluated feed flow rate

\begin{tabular}{cc}
\hline $\begin{array}{c}\text { Feed flow rate } \\
(\mathrm{L} / \mathrm{min}\end{array}$ & $\begin{array}{c}\text { Concentration of } \\
\text { Betamethasone }(\mathrm{ng} / \mathrm{L})\end{array}$ \\
0.8 & $<\mathrm{MQL}$ \\
1.2 & $<\mathrm{MQL}$ \\
2.4 & $<\mathrm{MQL}$ \\
3.2 & $<\mathrm{MQL}$ \\
\hline $\mathrm{MQL}=8 \mathrm{ng} / \mathrm{L}$ &
\end{tabular}

This removal could be occured since the cut-off point of DK membrane is 150 to $300 \mathrm{Da}$ and Betamethasone presents a molar mass above $393 \mathrm{~g} / \mathrm{mol}$, as can be seen in Table 4 in Chapter 2. Thus, the removal of these compounds by size exclusion was expected, however, as previously mentioned, this is not the only mescanism of solutesretention.

\subsubsection{Choice of feed flow rate}

Considering the set of results, that were obtained and evaluated during the variation of the feed flow, it was concluded that the best flow rate was $3.2 \mathrm{~L} / \mathrm{min}$.

\subsubsection{Recovery rate assessment}

\subsubsection{Recovery rate for physico-chemical analysis}

All samples (1-5) from the surface water were submitted to the stage of recovery rate verification by the DK nanofiltration. All permeates of each recovery rate presented similar results, as can be seen in the Figure 7 that shows the behavior of the conductivity for each permeate sample by evaluating its concentration from 10 to $90 \%$ of the recovery rate. 
FIGURE 7: Conductivity for the recovery rate for permeates of each surface water sample

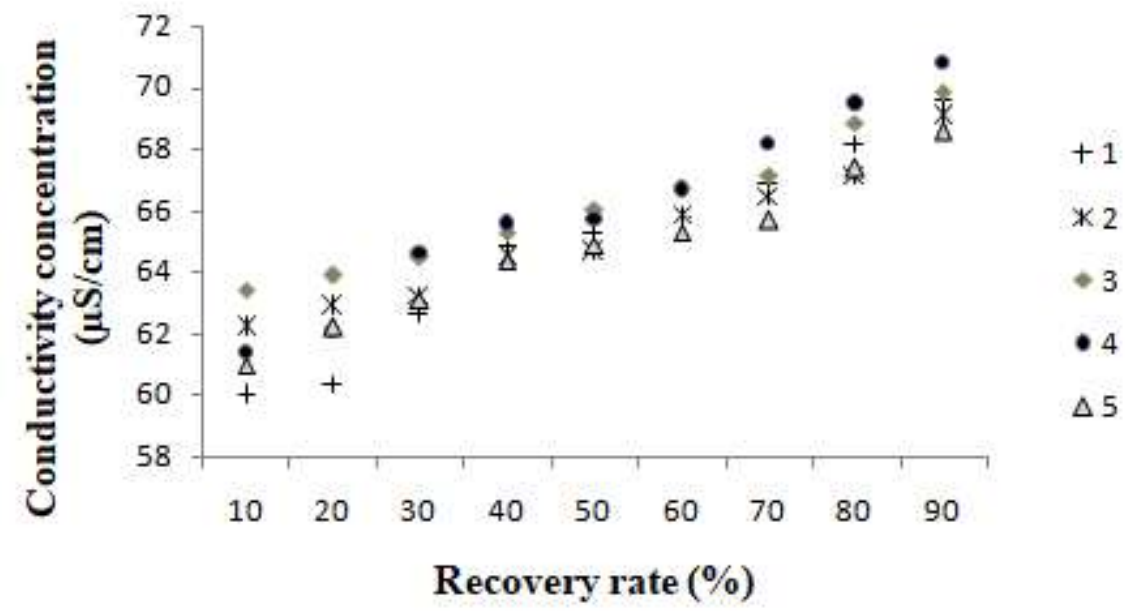

It can be seen from Figure 7 that the conductivity increased along the recovery rate, however, this increase was not expressive, since from the recovery rate of $10 \%$ to the rate of $90 \%$ the increase was of a maximum of $10 \mu \mathrm{S} / \mathrm{cm}$, which did not interfere with the quality of the permeate being kept below $100 \mu \mathrm{S} / \mathrm{cm}$. However, by Equation 10 the recovery rate for conductivity in all samples reached around $50 \%$.

Due to the similar behavior of all the samples during the evaluation of nanofiltration recovery rate, the first sample was chosen to illustrate the behavior of turbidity, absorbance and TOC along percentages of 10 to $90 \%$ of recovery. This sample was chosen because it presented the worst physico-chemical characterization among the samples evaluated in this study. The result of this evaluation can be seen in the graph of Figure 8 .

FIGURE 8: Turbidity, absorbance and TOC throughout the recovery rate for the first surface water sample

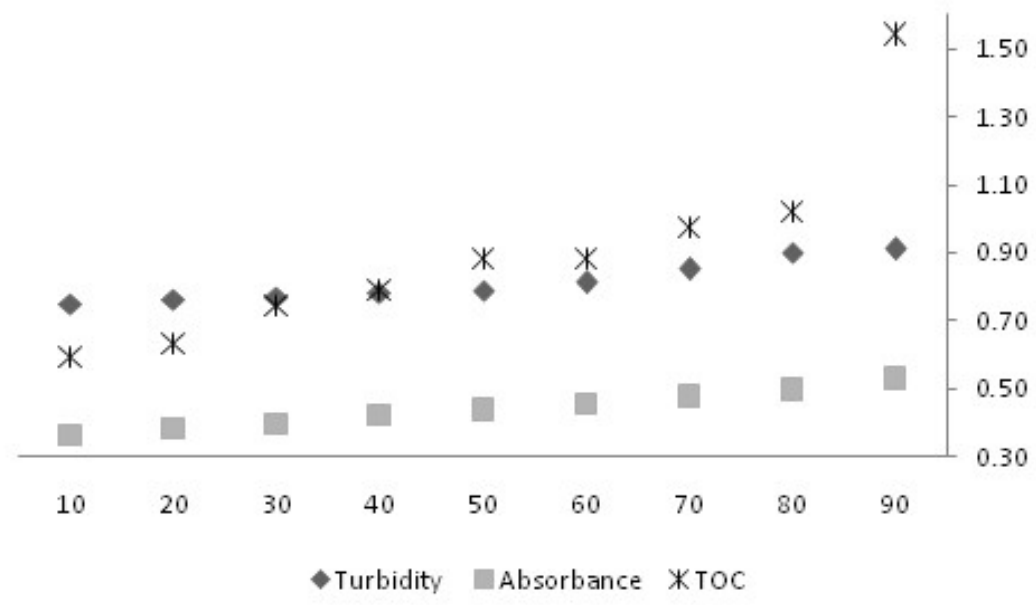

As can be seen in Figure 8, turbidity and absorbance had similar behaviors and their growths were practically linear. Although these two parameters increased along the recovery rate, it is 
noticed that this growth was more expressive for turbidity, since this parameter had a $17.5 \%$ increase comparing its first and last recovery rates. However, even with this increase, the turbidity measured at the last recovery rate is 100 times less than the maximum limit determined by Resolution of CONAMA 357/2005, which is 100 NTU for rivers of class 2 and for Potability standards N. 2914/2011 that presents as maximum allowed value 5 NTU fortrated water by complete cycle.

Absorbance throughout the recovery rate evaluation also had increased. Nevertheless, this growth in concentration was not very relevant, since from 10 to $90 \%$ of the recovery rate this parameter increased only $0.2 \mathrm{~nm}$. On the other hand, total organic carbon (TOC) increased during the recovery ratereaching at $1.54 \mathrm{mg} / \mathrm{L}$, representing a $59 \%$ increase in the value obtained at the first measurement of this parameter at the rate of $10 \%$. But, it is worth noting, as can be seen in Figure 8, that the expressive increase in TOC occurred from $80 \%$ of the recovery rate.

\subsubsection{Evaluation of the pharmaceutical compounds presence along the recovery rate}

The fisrt surface water sample (April 2016) was chosen to have its recovery rate analyzed in relation to the pharmaceutical compounds occurence. Pharmaceutical compounds removal along the recovery rate can be seen in Table 22 .

TABLE 22: Permeate flux and pharmaceuticals compounds removal in the first surface water sample (April 2016) along the DK membrane recovery rate

\begin{tabular}{|c|c|c|c|c|}
\hline & Permeate flux & Fluconazole & Phenylbutazone & Prednisone \\
\hline Surface water & $\left(\mathrm{L} / \mathrm{h} \cdot \mathrm{m}^{2}\right)$ & 227.52 & 132.72 & 50.24 \\
\hline $10 \%$ & 47.71 & $<\mathrm{MQL}$ & $<\mathrm{MQL}$ & $<\mathrm{MQL}$ \\
\hline $20 \%$ & 47.71 & $<\mathrm{MQL}$ & $<\mathrm{MQL}$ & $<\mathrm{MQL}$ \\
\hline $30 \%$ & 46.90 & $<\mathrm{MQL}$ & $<\mathrm{MQL}$ & $<\mathrm{MQL}$ \\
\hline $40 \%$ & 44.48 & $<\mathrm{MQL}$ & 48.80 & $<\mathrm{MQL}$ \\
\hline $50 \%$ & 43.67 & 64.48 & 49.36 & $<\mathrm{MQL}$ \\
\hline $60 \%$ & 43.67 & 99.51 & 50.40 & $<\mathrm{MQL}$ \\
\hline $70 \%$ & 42.86 & 100.48 & 51.52 & $<\mathrm{MQL}$ \\
\hline $80 \%$ & 42.05 & 156.32 & 97.24 & $<\mathrm{MQL}$ \\
\hline $90 \%$ & 41.24 & 169.84 & 99.36 & $<\mathrm{MQL}$ \\
\hline
\end{tabular}

$M Q L=8 n g / L$

Observing Table 22 it is possible to verify that during the entire recovery rate there was a reduction in the pharmaceutical compounds concentration that were found in surface water. 
However, applying Eq.10 the recovery rate of Fluconazole, Phenylbutazone, and Prednisone is respectively: $72 \%, 63 \%$ and $100 \%$.

During the recovery rate the permeate flux decreased, this fact was already expected, that during this rate the concentration of solutes in the feed increases, because the water (solvent of the feed) permeates the membrane and the concentrate returns to the feed tank which contributed to the occurrence of fouling, thus reducing the permeability of the membrane.t is noticed that the greatest decrease in permeability occurred from the rate of $40 \%$.

\subsection{Conclusions}

According to the evaluation performed for the best operating conditions for the MSP using the DK nanofiltration membrane, it was concluded that the best operating pressure was 10 bar and the flow rate was $3.2 \mathrm{~L} / \mathrm{min}$.

All permeates produced during the nanofiltration presented good physical and chemical quality, with efficiencies greater than $99 \%$ in the removal of turbidity and apparent color. In addition, the conductivity decreases in relation to raw waters, which are affected by conductivity greater than $100 \mu \mathrm{S} / \mathrm{cm}$. Considering the chemical and physical quality of permeates analyzing the data and permeate flux, it was determined that for the physical and chemical treatment the rate would be $40 \%$.

However, the efficiency of the pharmaceutical compounds removal along the recovery rate was also analyzed and it was observed that this efficacy was $100 \%$ up to the rate of $60 \%$. Thus, by analyzing of the physico-chemical characterization results and the pharmaceutical products retention, the resulting retention rate was $50 \%$.

\subsection{References}

AL MAMUN, A.M.D; BHATTACHARJEE, S; PERNITSKY,D; SADRZADEH, M. Colloidal fouling of nanofiltration membranes: development of a standard operating procedure. Membranes, 2017.

ABDELRASOUL, A; DOAN, H; LOHI, A. Fouling in membrane filtration and remediation methods, Mass Transfer-Advances in Sustainable Energy and Environment Oriented Numerical Modeling, 2013.

ANDRADE, L. H. Tratamento de efluente de indústria de laticínios por duas configurações de biorreator com membranas e nanofiltração visando o reúso. 2007. Dissertação de Mestrado. Universidade Federal de Minas Gerais, Belo Horizonte, Brasil. 
APHA - Standard Methods for the Examination of Water and Wastewater. 22 Ed. American Public Health Association, Washington,2012.

BANERJEE, P; DE, S. Steady state modeling of concentration polarization including adsorption during nanofiltration of dye solution. Sep. Purif. Technol, v. 71, p. 128-135, 2010.

DOLAR, DAVOR; KOŠUTIĆ, K. Removal of pharmaceuticals by ultrafiltration (UF), nanofiltration (NF), and reverse osmosis (RO). In: PETROVIC, Mira; BARCELO, Damia; PÉREZ, Sandra. (Eds.). Comprehensive Analytical Chemistry, v. 62. Oxford: Elsevier, 2013. Cap. 10, p. 319-344.

GARCÍA-MARTÍN，N; PEREZ-MAGARIÑO，S; ORTEGA-HERAS，M; GONZÁLEZ HUERTA, C; MIHNEA, M.; GONZÁLEZ-SANJOSÉ, M. L; PALACIO, L; PRÁDANOS, P; HERNÁNDEZ, A. Sugar reduction in mustswithnanofiltrationmembranestoobtainlowalcoholcontentwines. SeparationandPurification Technology, v. 76, p. 158-170, 2010.

HABERT, A. C; BORGES, C. P; NOBREGA, R. Processos de Separação por Membranas. Rio de Janeiro: E-papers, 2006.

HOEK, E.M.V; ELIMELECH, M. Cake-enhanced concentration polarization: A new fouling mechanism for salt-rejecting membranes. Environ. Sci. Technol, v. 37, p. 5581-5588, 2003.

JELIC, A; GROS, M; GINEBREDA, A; CESPEDES-SÁNCHEZ, R; VENTURA, F; PETROVIC, M; BARCELO, D. Occurrence, partition and removal of pharmaceuticals in sewage water and sludge during wastewater treatment. Water Research, v. 45, p.1165-1176, 2011.

KOYUNCU, I; TURAN, M; TOPACIK, D; ATES, A. Application of low pressure nanofiltration membranes for the recovery and reuse of dairy industry effluents, Water Sci. Technol, v. 41, p.213-221, 2000.

KUDLEK, E ; BOHDZIEWICZ, J; DUDZIAK, M. Influence of water matrix on the retention of pharmaceuticals by high-pressure membrane filtration-EcolChemEng A, v. 22, p. 469-479, 2015.

LÓPEZ-SERNA, R; PETROVIC, M; BARCELO, D. Occurrence and distribution of multiclass pharmaceuticals and their active metabolites and transformation products in the Ebro River basin (NE Spain). Science of the Total Environment, v. 440, p. 280-289, 2012.

MATTARAJ, S; JARUSUTTHIRAK, C; CHAROENSUK, C; JIRARATANANON, R. A combined pore blockage, osmotic pressure, and cake filtration model for crossflow nanofiltration of natural organic matter and inorganic salts, Desalination, v. 274, p. 182 191,2011 .

MULDER, M. Basic Principles of Membrane Technology, 2nd ed.; Kluwer Academic: Dordrecht, The Netherlands, 1996.

RADJENOVIC, J; PETROVIC, M; VENTURA, F; BARCELO, D. Rejection of pharmaceuticals in nanofiltration and reverse osmosis membrane drinking water treatment. Water Research, v. 42,p. 3601-3610, 2008. 
RICHARDS, L. A.The removal of inorganic contaminants using nanofiltration and reverse osmosis, 2012. Doctoral dissertation, Heriot-Watt University.

TAHERAN, M; BRAR, S. K; VERMA, M; SURAMPALLI, R.Y; ZHANG, T.C; VALERO, J.R. Membrane processes for removal of pharmaceutically active compounds (PhACs) from water and wastewaters. Science of the Total Environment,v.547,p.60-77, 2016.

TANG, C.Y; CHONG, T.H; FANE, A.G. Colloidal interactions and fouling of NF and RO membranes: A review. Adv. Colloid Interface Sci, v. 164, p. 126-143, 2011.

YAN, Q; GAO,X; CHEN,Y; PENG, X; ZHANG, Y; GAN, X; ZI, C; GUO, J.Occurrence, fate and ecotoxicological assessment of pharmaceutically active compounds in wastewater and sludge from wastewater treatment plants in Chongqing, the Three Gorges Reservoir Area.Science of the Total Environment, v. 470, p.613-630,2013. 


\section{CONSIDERATIONS}

Throughout this study, the pharmaceutical compounds occurrence was evaluated in the Doce river raw water, which did not present significant quantities and varieties among the 16 drugs that were investigated in this search, because that were found just Betamethasone, Fluconazole, Phenylbuthazone and Prednisone in the surface water that was collected during one year.

This may have happened because the collection of these samples had been carried out in the surface water in only one point. It is inferred that this collection should cover other points and depths of the river. Nevertheless, it does not mean that this river is not contaminated by pharmaceutical products, mainly since the sewage is discharged in natural waters without any treatment. What can be seen from this study is that the Doce river may have other pharmaceutical compounds. As has been said previously, the analysis of the drugs occurrence in natural waters is very sensible to seasonal phenomena and care in the collect.

All the nanofiltration and reverse osmosis membranes evaluated in this study showed a reduction in the concentration of the pharmaceutical products in permeates when compared to the Doce river raw water that served as feed in the MSPs. Among the membranes evaluated, the DK nanofiltration membrane (150-300 Da) was highlighted because it produced a higher volume of permeate with good physical and chemical quality, besides the drugs retention, resulting in a lower demand of specific energy compared to the other membranes analyzed in this study. This good quality of permeate with low specific energy consumption are some of the factors that encourage the application of nanofiltration in water treatment in wich high quality is desired.

For laboratory and full scale application it is necessary to evaluate the best operating conditions in order to obtain the best permeate flux ratio with selectivity and lower energy expenditure. In this way, four transmembrane pressures and four different feed rates were analyzed, and permeates generated for each condition were analyzed for the retention of the pharmaceutical compounds and the physical-chemical quality of each one. The best results for the evaluated parameters were obtained by applying a pressure of 10 bar with a feed rate of 3.2 L / min, as a result of the highest flow with the lowest specific energy demand.With this established operational condition, the best physical-chemical quality for permeates was reached among all the operational conditions evaluated in this study. In relation to the removal of the pharmaceutical compounds, the surface water of the Doce river, that was 
collected in January 2017, was used as feed for this test. This sample presented only the Betamethasone, which was retained by the DK membrane in all the evaluated conditions.

As could be observed in this research, the Central WTP of Governador Valadares, which is contemplated by the conventional water treatmentfor human consumption, showed good efficiency in reducing the concentration of the pharmaceutical products found in the Doce river raw water.This is not to say that WTP is efficient in the other drugs removalthat may be present in the Doce river. The choice of investigating 16 pharmaceutical products was due to the high price of the analytical standard of each drug and the high cost of HPLC coupled to the mass spectrometer analysis for the quantification and confirmation of each of these compounds in the raw and treated water. Each injection for investigation of the drugs costs an average of $R \$ 400.00$ and all these evaluations were carried out for the samples with neutral $\mathrm{pH}$ and for the $\mathrm{pH} 2$. In addition, it should be mentioned, the difficulty to establish effective methodologies for the quantification of each pharmaceutical product. This is a timeconsuming phase, since this analysis is very sensitive, insofar as all the samples evaluated in this study are natural matrices, presenting several compounds in the Doce river surface water, and these solutes made the drug quantification process more difficult.

Although the Central WTP of Governador Valadares showed good efficiency in the removal of the four pharmaceutical compounds that detected in the surface water. This efficiency in the removal may be due to the atypical operating conditions of which the treatment plant was operating, since with the rupture of the tailings dam of the Samarco mining company, the Doce River was reached by the sediments and the Central WTP of Governador Valadares probably used a greater volume of coagulants, fluaculants and chlorine in the process of water treatment to meet the standards established by ordinance 2914/2011. Thus, this probable use of more chemical reagents may have favored the removal of the pharmaceutical compounds found in surface water. It is necessary to emphasize that it is not known the efficiency in other pharmaceutical compounds removal that may be present in the water of the Doce river, which were not contemplated in this study, but may be present in surface water.

In addition, the focus of this study was the removal of pharmaceuticals compounds, however, it is known that for drinking water other parameters are very importantto be monitored. As was seen throughout this study, MSP, using nanofiltration orreverse osmosis, presented good results of the removal of turbidity, color, absorbance, conductivity and TOC, thus being an auxiliary treatment of water intended for human consumption, and that may be used in emergency situations, such as what occurred in November 2015 on the Doce river. 
Therefore, the system of public water supply would not be so impaired if it were contemplated by an auxiliary treatment system. However, it is necessary to remember that in order to apply the MSP in such situations, it would be necessary to pre-treat the water, such as the application of water coagulation and microfiltration, to prevent the early fouling occurrence in the membrane thus reducing its life span.

Moreover, in order to better evaluate the mechanisms of rejection between the pharmaceutical compounds and the membranes, it is recommended to perform themorphological analysis of the membrane surface before and after permeation to also obtain the fouling characteristics. This type of analysis is important for the application of nanofiltration, or other types of MSP, in real scale, since it will be easier to predict also how the fouling occurs and what better mechanisms to avoid it without greatly increasing the operating costs in addition, in order to avoid fouling by causing suspended solids on a real scale, it is necessary to adopt microfiltration pretreatment, which will contribute to the removal of these and other physical compounds that may compromise the permeability of the nanofiltration membrane. 